\author{
Universidade de São Paulo \\ Escola de Artes, Ciências e Humanidades \\ Programa de Pós-graduação em Mudança Social e \\ Participação Política
}

FERNANDA FERNANDES DOS SANTOS

Escola de Samba em São Paulo: Identidade e Engajamento 
FERNANDA FERNANDES DOS SANTOS

\section{Escola de Samba em São Paulo: Identidade e Engajamento}

Dissertação apresentada ao Programa de PósGraduação em Mudança Social e Participação Política, da Escola de Artes, Ciências e Humanidades, da Universidade de São Paulo, para obtenção do título de Mestre em Ciências.

Orientador: Prof. Dr. Dennis de Oliveira.

SÃO PAULO 
Autorizo a reprodução e divulgação total ou parcial deste trabalho, por qualquer meio convencional ou eletrônico, para fins de estudo e pesquisa, desde que citada a fonte.

\section{CATALOGAÇÃO-NA-PUBLICAÇÃO}

Biblioteca

Escola de Artes, Ciências e Humanidades da Universidade de São Paulo

\section{Santos, Fernanda Fernandes dos}

Escola de Samba em São Paulo : identidade e engajamento /

Fernanda Fernandes dos Santos; orientador, Dennis de Oliveira. - São Paulo, 2013.

$114 \mathrm{f}$.

Dissertação (Mestrado em Ciências) - Programa de PósGraduação em Mudança Social e Participação Política, Escola de Artes, Ciências e Humanidades, Universidade de São Paulo.

Versão corrigida.

1. Escolas de samba - São Paulo. 2. Carnaval - São Paulo. 3. Identidade cultural. 4. Relações étnicas e raciais. 5. Interação social (Sociologia). 6. Afro-descendentes. I. Oliveira, Dennis de, orient. II. Título. 
SANTOS, Fernanda Fernandes dos

Escola de Samba em São Paulo: Identidade e Engajamento

Dissertação apresentada ao Programa de PósGraduação em Mudança Social e Participação Política, da Escola de Artes, Ciências e Humanidades, da Universidade de São Paulo, para obtenção do título de Mestre em Ciências. Orientador: Prof. Dr. Dennis de Oliveira

Aprovada em:

\section{BANCA EXAMINADORA}

Prof. Dr. Dennis de Oliveira (orientador)

Instituição: Escola de Artes, Ciências e Humanidades (EACH/USP)

Programa de Pós-Graduação em Mudança Social e Participação Política (Promuspp)

Assinatura:

Prof. Dr. Alessandro Silva Soares

Instituição: Escola de Artes, Ciências e Humanidades (EACH/USP)

Programa de Pós-Graduação em Mudança Social e Participação Política (Promuspp)

Assinatura:

Prof. Dr. Silas Nogueira

Instituição: Centro Universitário Moura Lacerda/ Ribeirão Preto

Assinatura: 


\section{DEDICATÓRIA}

Dedico esta dissertação a meus pais José Fernandes dos Santos Filho (Seu Zequinha) e Maria Salva Carvalho dos Santos (dona Salvinha). Eles me deram vida, me fizeram crescer. Sempre alimentando meu corpo e minha mente. Quando minha mente ultrapassou os muros de casa, encorajaram minha ousadia e ampararam minha busca pelo conhecimento. São exemplos a serem seguidos.... Benção minha mãe, benção meu pai.... 


\section{AGRADECIMENTOS}

Agradeço a meu orientador professor doutor Dennis de Oliveira pela mão estendida quando houve o escorregão, pela tranquilidade no meu desespero, pela bronca nos meus momentos de desvio, pelo sorriso e pelo carinho. Sem você, professor Dennis, eu não teria conseguido.

Aos demais professores do Programa de Pós-Graduação em Mudança Social e Participação Política. Ao todos os companheiros do mestrado, citar alguns seria injusto com os demais.

Ao meu amigo e jornalista Dalton Luís Ferreira que ensinando sobre o carnaval da capital paulistana, despertou em mim o interesse em fazer dessa festa meu campo de pesquisa.

Aos meus irmãos, cunhados, sobrinhos e demais familiares por entenderem que muitas vezes me ausentei do convívio para me dedicar aos estudos.

Para meus amigos mais chegados, por terem secado as tantas lágrimas que derramei no doloroso processo que é escrever uma dissertação. Em especial para Rachel Tavares Ancelevicz e Leonardo Pimentel Paulino pela leitura do texto.

Para minha família religiosa (de santo) que me deu energia e equilíbrio nas horas em que tudo parecia fugir de controle.

Aos presidentes Angelina Basílio, da Rosas de Ouro, Darly Silva, o Neguitão, da Vai-Vai e Edilson Carlos Casal, o Nego, da Pérola Negra, pelo carinho e pela confiança. 


\title{
RESUMO
}

Esta pesquisa tem por objetivo estudar os processos de construção de identidade desenvolvidos nas escolas de samba de São Paulo e verificar como esses processos motivam o engajamento dos sujeitos em atividades não remuneradas, durante a preparação dos desfiles das agremiações. Para tanto, utilizou-se os referenciais conceituais de identidade e reconhecimento de Axel Honneth e Nancy Fraser, os conceitos de cultura negro-brasileira de Muniz Sodré e Nei Lopes, articulando-os com os movimentos de inserção de afrodescendentes na sociedade brasileira e paulista, marcados pela tensão entre a opressão racista e as resistências antirracistas. Além disso, foi realizada uma pesquisa de campo utilizando a metodologia da etnografia, análise de conteúdo e entrevistas semiestruturadas com participantes da harmonia e da bateria de três escolas de samba do Grupo Especial de São Paulo: Vai-Vai, Rosas de Ouro e Pérola Negra. Esta pesquisa propõe que os processos identitários dos negros nas escolas de samba inserem-se na perspectiva de resistência aos mecanismos de opressão.

Palavras-chave: reconhecimento; identidade; engajamento; resistência; escola de samba.

\begin{abstract}
This research discusses the processes of identity construction within samba schools in São Paulo, Brazil, and how such processes fosters the commitment of individuals towards nonpaid activities during the preparations for the schools' parades. Axel Honneth's and Nancy Fraser's framework of identity and acknowledgement were used, as well as Muniz Sodré's and Nei Lopes' concepts of African Brazilian culture, linking them with movements for the inclusion of African descendants in the Brazilian and the paulista communities, which are marked by tensions between racist oppression and anti-racist resistances. One of the guidelines of this research is that the processes of identity building for black people in samba schools are inserted in the resistance to the mechanisms of oppression. A field research was conducted using the ethnography methodology combined with content analysis and semisctructured interviews with members of two sectors (namely, the harmonia and the bateria) of Vai-Vai, Rosas de Ouro and Pérola Negra - three samba schools from the Grupo Especial, the main group of samba schools in the city.
\end{abstract}

Keywords: identity; commitment; samba school. 


\section{SUMÁRIO}

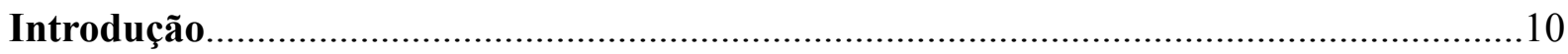

Capítulo 1: O samba de São Paulo e as escolas de samba paulistanas..............................14

1.1 Festa dos santos católicos: o prenúncio do samba paulistano................................14

1.2 Bom Jesus de Pirapora, Nossa Senhora do Rosário, Igreja dos Enforcados: reuniões do povo negro e locais de apresentação do samba paulistano.

1.2.1 Os caiapós

1.3 A imigração e seus os efeitos sobre as comunidades negras e sobre o samba.

1.4 Procissões, paradas militares e Carnaval: origens dos cordões e das escolas de samba de São Paulo.

1.5 Cordões carnavalescos e escolas de samba .33

1.5.1 Barra Funda, Bela Vista e Glicério. 33

1.5.2 A rivalidade entre os cordões: quando a brincadeira era vencida por quem roubava a bandeira da outra agremiação.

1.5.3 As partes de uma escola de samba

1.6 Cenário da pesquisa.

Capítulo 2: Identidade e escola de samba.

2.1 Os tipos de reconhecimento. 44

$2.2 \mathrm{O}$ reconhecimento do novo ente pela família.

2.3 O reconhecimento da escola de samba no espaço jurídico. 50

2.4 O reconhecimento do ser como parte do todo........

2.5 Quando a cultura dominante absorve a cultura subalterna: a entrada de contingentes brancos nas escolas de samba paulistanas.

$2.6 \mathrm{O}$ vínculo, o compromisso e o engajamento nas agremiações carnavalescas 65 
Capítulo 3: Metodologia, descrição densa da vivência em campo e análise dos dados

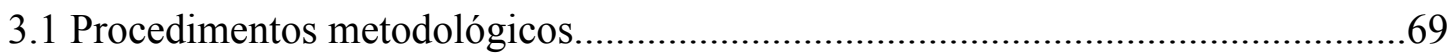

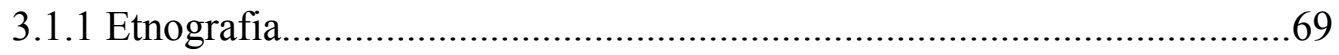

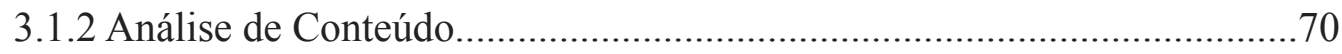

3.2 Descrição densa do trabalho de campo etnográfico e análise dos dados.................71

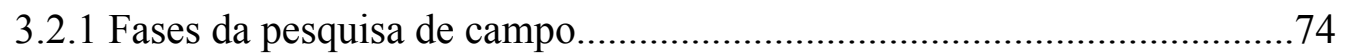

3.2.2 A observação não participante e motivação de pesquisa..........................75

3.3 A escolha do método de pesquisa e de análise dos dados....................................77

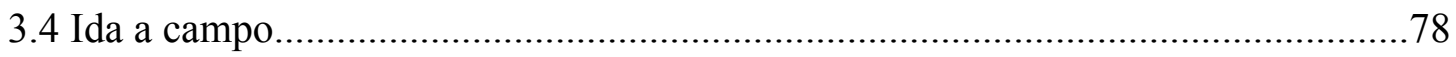

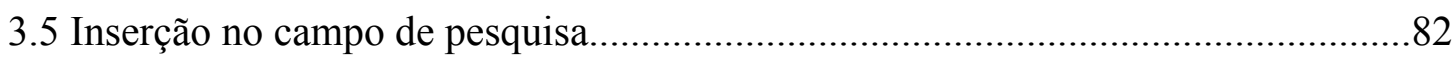

3.5.1 Dificuldades da observação não participante...........................................83

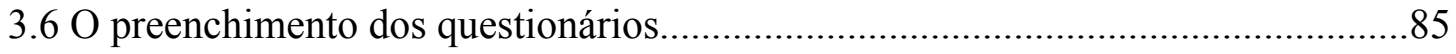

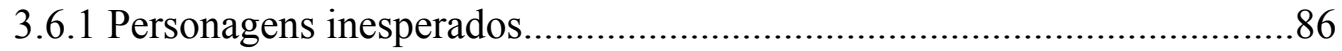

3.6.2 A alegria disciplinada dos ritmistas e a disciplina ritmada dos harmonias. .87

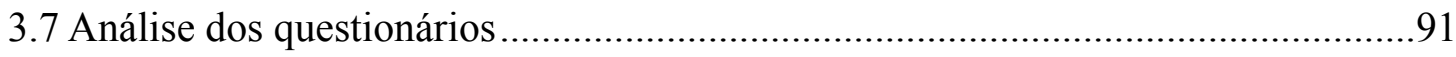

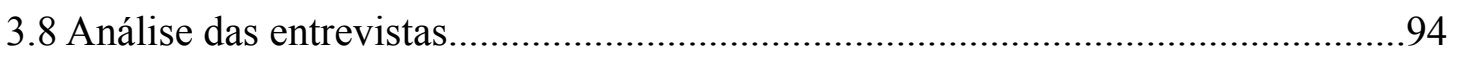

3.8.1 Situando as entrevistas e os entrevistados...........................................94

3.8.2 Como foram analisadas as entrevistas..............................................95

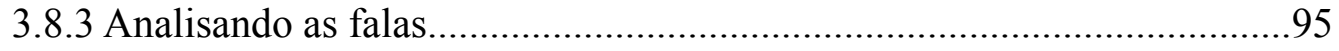

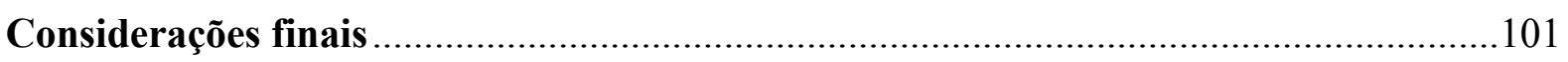

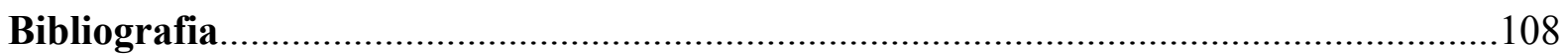

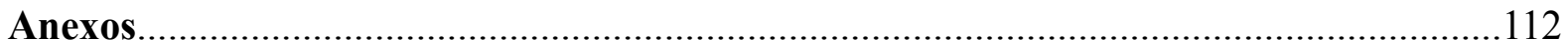

Anexo A - Notas atribuídas às escolas de samba.....................................................112

Anexo B - Modelo do Termo de Consentimento Livre Esclarecido............................113

Anexo C - Roteiro semiestruturado de entrevistas...................................................114 


\section{Introdução}

Em 2010, a disputa pelo título de melhor escola de samba do Grupo Especial do Carnaval da Cidade de São Paulo, foi vencida pela Sociedade Rosas de Ouro. A agremiação não obtinha a vitória do concurso havia 16 anos e o título foi disputado quarto de centésimo por quarto de centésimo com a Mocidade Alegre, vencedora do Carnaval de 2009. A decisão ocorreu na última nota do último quesito: comissão de frente. A escola sagrou-se vitoriosa porque duas das notas atribuídas para a Mocidade Alegre foram menores que as da Rosas de Ouro. A diferença de 25 centésimos conduziu o título para a ponte da Freguesia do Ó e não para o Limão, bairros da zona norte da capital paulista (Cf. Anexo A).

A acirrada disputa fez com que a imprensa, que cobria o evento, deixasse a mesa da Mocidade Alegre, que fora campeã no ano anterior e recebia boas notas e se direcionasse para a da Rosas de Ouro, que também recebia boas notas, mas não vencia havia anos o certame.

Enquanto a escola acolhia o troféu, comemorava a vitória e recebia os cumprimentos, o presidente da escola de samba Pérola Negra correu em direção à torcida que assistia à apuração. A atitude inesperada fez com que olhares desconfiados aguardassem possíveis brigas, uma vez que os ânimos durante a apuração ficaram exaltados. Ao contrário do imaginado, não ocorreu contenda. Os poucos torcedores que acompanhavam a apuração no sambódromo do Anhembi, cumprimentaram e aclamaram o presidente.

Este ato isolado chamou a atenção de quem havia acompanhado a preparação e o desfile da Pérola Negra, no Carnaval de 2010, quando a agremiação encerrou o desfile das escolas de samba do Grupo Especial do Carnaval de São Paulo, com uma apresentação colorida, descontraída e que emocionou o público das arquibancadas do sambódromo, ao retratar a história de vida do ator, cantor e apresentador Rolando Boldrin - artista que prima pela valorização da música, da dança, das histórias e das expressões artísticas representantes da variedade de sotaques, cores, sabores e festejos do povo brasileiro.

Em virtude da reação do público do sambódromo, os integrantes da escola estavam acreditavam que a Pérola Negra, escola que desfilava pela quarta vez consecutiva no grupo especial, conseguiria obter uma classificação melhor que a dos anos anteriores: ela era a décima primeira colocada no primeiro desfile de retorno ao grupo especial, em 2007, décima colocada no segundo ano e nona no desfile de 2009. A Pérola Negra estava em ascensão. 
Nos primeiros cinco quesitos (mestre-sala e porta-bandeira, alegoria, samba-enredo, fantasia e enredo) a escola estava empatada com a Rosas de Ouro, com a Mocidade Alegre e com a Unidos de Vila Maria, escolas que ficaram com as três primeiras colocações na disputa de 2010. A partir do quesito bateria, sexto item do julgamento, a escola não manteve o padrão das notas e a cada pontuação anunciada perdia posições.

Ao final da apuração, a Pérola Negra ficou em penúltima colocação, dentre as escolas que participaram da disputa. Classificação oposta às escolas Rosas de Ouro, Mocidade Alegre e Unidos de Vila Maria com as quais empatara no início da disputa e que obtiveram, respectivamente, as três primeiras colocações.

As notas baixas atribuídas à escola de samba Pérola Negra, durante a apuração, deslocaram a agremiação da primeira colocação para o rebaixamento. Porém, as altas notas atribuídas à comissão de frente, ao final da apuração, mantiveram a escola no grupo especial. As notas atribuídas aos quesitos harmonia, bateria e evolução foram as menores da escola, naquele ano.

A harmonia e a bateria, dois dos quesitos que obtiveram as piores avaliações no conjunto de notas da escola, ficam sob a responsabilidade de um grupo de pessoas que atua na escola de samba durante o ano todo, no caso do primeiro quesito e da ala musical da escola que também participa da agremiação durante um longo período do ano, no caso do segundo quesito.

A Pérola Negra recebeu excelentes notas em quesitos plásticos (alegoria, fantasia, enredo): itens pensados pelo carnavalesco e desenvolvidos por artistas e profissionais, pagos para a execução da tarefa. Nos itens cuja participação popular foi julgada por meio do canto, da dança e do ritmo, as notas ficaram abaixo do esperado. A diferença entre as notas recebidas pela escola em quesitos plásticos e nos que primaram pela participação humana conduziu a uma reflexão mais ampla sobre os responsáveis pela bateria, evolução e harmonia nas escolas de samba em geral.

Tanto os responsáveis pelos quesitos plásticos como os incumbidos da participação humana, integram ativamente as atividades da agremiação durante todo o ano carnavalesco, que se inicia pouco depois da divulgação da escola de samba campeã do Carnaval anterior e termina no dia do desfile (BLASS, 2007). O comportamento destes dois tipos de profissionais difere, porém, quanto ao vínculo que estabelecem com as escolas de samba, as 
responsabilidades, os encargos e os benefícios que as atividades podem ou não trazer para seus executores.

Este estudo enfocou os responsáveis pelos quesitos cuja avaliação está relacionada ao desempenho das atividades dos elementos humanos: cantar e dançar, e tocar os instrumentos musicais, ações do desfile balizadas pelo regulamento. Esses responsáveis têm funções diferentes dentro da agremiação. Nas escolas de samba, "os harmonias"1 são os responsáveis por dois quesitos: eles incentivam o canto dos foliões, (julgado no quesito harmonia) e organizam e estimulam a dança e a progressão dos foliões (julgados no quesito evolução). $\mathrm{O}$ outro grupo que despertou a atenção, por ter causado tantos problemas para a Pérola Negra, foi o da bateria, composta por ritmistas. Eles que são responsáveis por tocar os instrumentos e manter o ritmo da escola durante todo o desfile.

A pergunta que direcionou as pesquisas desenvolvidas nesse estudo relaciona-se aos dois grupos descritos: por que esses grandes grupos trabalham sem remuneração? Para respondê-la, ao longo de três anos foram observadas as atividades dessas pessoas durante a cobertura jornalística dos eventos do carnaval paulistano que desenvolvemos. O levantamento bibliográfico prévio, sobre carnaval e escolas de samba, evidenciou a inexistência de discussões sobre o assunto proposto. Observou-se que não existiam livros ou pesquisas sobre o carnaval paulistano que contemplassem esses grupos que despertaram nosso interesse. Decidiu-se, a partir desta constatação, pesquisar e retratar a importância das atividades de os "harmonias" e ritmistas, nas escolas de samba.

No primeiro capítulo dessa pesquisa foi realizado um levantamento histórico sobre a origem do samba e dos desfiles carnavalescos, tendo como base as obras de Olga Von Simson, Maria Aparecida Urbano, Edson Roberto de Jesus e José Geraldo Vinci de Moraes. As propostas desenvolvidas por Nei Lopes e Muniz Sodré auxiliaram a apresentação dos fundamentos da cultura de origem africana, presente nas escolas de samba da capital. Além disso, a obra de Roberto Damatta auxiliou a compreensão do perfil de organização do Carnaval.

No segundo capítulo, as teorias de Axel Honneth, Nancy Fraser e Antonio da Costa Ciampa, que tratam da identidade e do reconhecimento, foram utilizadas para evidenciar as formas pelas quais o componente integra-se à escola de samba. A contextualização de um dos

\footnotetext{
${ }^{1}$ O quesito "harmonia" é diferenciado do responsável, "o harmonia", por meio de diferentes utilizações do artigo definido: feminino no primeiro caso, e masculino no segundo.
} 
conceitos de Honneth, para a sociedade brasileira de origem africana, foi realizada por meio das pesquisas de Robert W. Slenes sobre o compadrio - relações iniciadas no período escravista da História do Brasil. Além disso, os estudos de Dennis de Oliveira e Muniz Sodré indicaram a maneira pela qual os componentes das culturas subalternas relacionam-se com a cultura hegemônica e com se dá a relação dessas pessoas com a realidade circundante. Durante o processo de autorreconhecimento que leva o folião a se identificar com a escola, é estabelecido um vínculo que leva ao comprometimento com a agremiação. Os escritos de Pichon-Rivière e Gilberto Freire auxiliaram a discussão dessa temática.

O terceiro capítulo apresenta a metodologia do trabalho de campo, a Etnografia, a partir das ideias de Clifford Geertz e Telmo Caria, e a análise de conteúdo, balizada pelos conceitos de Laurence Bardin, que serviu para o estudo dos dados obtidos. Nesse mesmo tópico, o material obtido durante o trabalho de campo foi analisado: desde a descrição densa do que foi vivenciado em campo, passando pela análise quantitativa das respostas do questionário aplicados aos integrantes de três escolas de samba escolhidas, terminando com a análise qualitativa das entrevistas feitas com cinco integrantes das escolas pesquisadas.

O último capítulo apresenta a conclusão da pesquisa, em que as respostas dos entrevistados foram analisadas conforme a teoria apresentada nos capítulos anteriores.

A presente dissertação foi estimulada pela curiosidade que os desfiles de escola de samba suscitou: não aquele desfile que recebe cobertura jornalística televisiva, impressa, radiofônica ou pela internet, mas sim o desfile que marca a presença do elemento humano, responsável por tornar vivaz e emocionante a apresentação da escola de samba. 


\section{Capítulo 1: O samba de São Paulo e as escolas de samba paulistanas}

Pode chegar que a festa vai é começar agora E é prá chegar quem quiser, deixe a tristeza prá lá E traga o seu coração, sua presença de irmão Nós precisamos de você nesse cordão Gonzaguinha, $\mathrm{O}$ homem falou

Este capítulo tem por objetivo contextualizar o cenário da pesquisa: o carnaval paulistano desenvolvido entre o final da primeira e início da segunda década do século XXI. Porém, para o estudo do carnaval paulistano, que tem origem e desenvolvimento diferentes do carioca, foi necessário retroceder ao final do século XIX, período da abolição da escravidão e quando os recém-libertos passaram a ter acesso à rua. Objetivando facilitar a leitura e contextualização, o capítulo foi dividido em tópicos, que vão desde o período escravista - em que grupos de origem africana apresentavam-se para os donos das fazendas - até a primeira década do século XXI.

\subsection{Festa dos santos católicos: o prenúncio do samba paulistano}

O samba paulistano foi criado, desenvolveu-se e adquiriu as características que the deram corpo, a partir da metade do século XIX (MORAES, 1989; JESUS, 2004; SIMSON, 2007). Neste período, o estado de São Paulo deixava de ser uma pequena e regional província e tornava-se a mais próspera do país. Assim como o Nordeste, durante o ciclo da cana de açúcar e Minas Gerais, no período da mineração, São Paulo era o estado financeiramente mais abastado, no final do século XIX. O café foi amplamente cultivado no oeste paulista depois de esgotar a terra na região do Vale do Paraíba. Como nos ciclos produtivos anteriores, a economia dependia quase que exclusivamente da mão de obra dos afrodescendentes escravizados.

O ciclo do café, período comandado pela aristocracia, atravessava dificuldades para aquisição de mão de obra escrava, pois o tráfico era combatido pelos abolicionistas, que buscavam melhores condições de vida para os negros, e também pelos ingleses, credores do Brasil, que objetivavam ampliar os mercados consumidores dos seus bens manufaturados produzidos depois da Revolução Industrial.

Com a dificuldade para a aquisição de novos escravos, principalmente devido à pressão inglesa, muitos fazendeiros passaram a comprá-los de outros proprietários, o que levou a migração de escravos dentro do Brasil. Muitos saíram do Nordeste, cuja produção 
estava em decadência, para trabalhar no Sudeste. Além da dificuldade de aquisição mencionada, a mudança do governo, de monarquista para republicano, e a imigração estrangeira, foram fatores que diferenciaram o ciclo do café dos anteriores.

Durante o ciclo do café a capital da província de São Paulo assumiu importância semelhante à da capital do Império: se o Rio de Janeiro era a capital política, São Paulo era a capital financeira. Nos ciclos anteriores, os proprietários de terras viajavam à corte (Salvador ou Rio de Janeiro) para fechar negócios, para vender ou comprar escravos. No ciclo do café, o fazendeiro vinha à capital da província de São Paulo com os mesmos objetivos (JESUS, 2004). Pouco depois, ainda no século XIX, o Rio de Janeiro transformou-se em capital federal. A capital da província São Paulo passou a ser um ponto de negócios, adquirindo uma importância até então não imaginada para a região. A mudança das características da mão de obra e do sistema de governo ocorreu nos anos subsequentes: em 1888, houve a assinatura da lei Áurea e em 1889, a Proclamação da República.

Com alterações tão profundas no panorama nacional, a aristocracia buscava se adaptar aos novos modelos, mas não abandonou antigos conceitos. Dentre eles, o da inferioridade intelectual da população negra. O preconceito contra o afrodescendente foi perpetuado quando ele passou da condição de escravo para a de liberto: a alforria não conduziu à emancipação porque ao liberto foi negada a manutenção do trabalho que realizava ou a obtenção de outro emprego (FERNANDES, 2008). Depois da Abolição, a experiência na atividade que o afrodescendente exerceu por toda a vida foi descartada e não foi recrutada para o trabalho assalariado.

Por que substituir os recém-libertos, que realizaram o trabalho por mais de 300 anos,pelos imigrantes? Fernandes (2008) propõe que a imigração europeia foi estimulada em virtude de uma política governamental de branqueamento da população, sendo a necessidade de mão de obra especializada um argumento de menor importância.

A argumentação dos políticos desse momento histórico, que recusavam o uso da mão de obra afrodescendente, estava calcada no preconceito quanto a origem africana dessas pessoas e não na baixa produção resultante das condições da escravização, da falta de tratamento humanizado e da condição sub-humana a qual essas pessoas estavam submetidas (GUIMARÃES, 2004).

O novo modelo do governo brasileiro baseava-se na crença de que o branqueamento da população brasileira levaria ao rápido desenvolvimento do país. O novo paradigma político 
do país pregoava que o trabalho realizado pelo povo negro, em três séculos de escravidão, durante o período monárquico, não era o ideal para a nova fase republicana. $\mathrm{O}$ trabalho do escravo, com a dependência total do servo ao senhor, destoava dos preceitos republicanos. Em contrapartida, o trabalho assalariado, conhecido e praticado pelos europeus, tornara-se o objetivo do novo modelo de governo (FERNANDES, 2008). O imigrante não era visto como invasor -diferentemente do ocorrido com os holandeses, no Nordeste, entre 1624 e 1654 . Ele era considerado uma espécie de salvador, uma vez que tomaria o lugar dos afrodescendentes escravizados (FERNANDES, 2008).

A abolição da escravidão possibilitou aos afrodescendentes o livre acesso às ruas, demonstrando que a escravidão, como modelo de dominação dos afrodescendentes tinha sido extinto. Mas, a liberdade de sair à rua contrastava com falta de oportunidades do mercado de trabalho, no final do século XIX.

Nas idas e vindas em busca de empregos ou, no caminho percorrido para chegar até eles, os afrodescendentes paravam, conversavam e debatiam ideias e ideais. Às vezes, o período em que o grupo de afrodescendentes ficava reunido lhe permitia entoar cantos, cantigas, resultando cantorias que afloravam desses encontros.

O povo africano, principalmente o de origem banta que compôs a maioria dos escravizados trazidos ao Brasil, considerava o "cantar" como uma forma de se alcançar o divino, o sagrado. O costume veio da África e desembarcou no Brasil (LOPES, 1992). Não foram poucos os relatos dos cantos entoados pelos escravizados nas lavouras de cana de açúcar, no nordeste do Brasil ou em Minas Gerais, durante o período da mineração. O uso do canto, como forma de reverência ao sagrado, tornou-se ainda mais visível, durante o período de exploração da cana de açúcar, em São Paulo, com a participação dos escravizados nas festas religiosas católicas.

Esse costume rural, originado nas festas africanas e adaptado nos ciclos exploratórios do Brasil, foi trazido para a capital paulista antes da província tornar-se importante. Os festejos católicos, até o início do ciclo do café, eram praticamente os únicos meios de diversão na capital paulista: tanto para ricos como para pobres, para negros ou para brancos. Era um dos poucos momentos, no cotidiano repleto de estratificações e segregações da capital paulista, em que todos conviviam - apesar da diferença social ser percebida, entre outras formas, pelos trajes (JESUS, 2004). 
Havia a crescente presença de negros libertos, devido às leis que alforriavam os maiores de sessenta anos (Lei do Sexagenário) e os que nascessem depois de um determinado período (Lei do Ventre Livre). Essas não eram as únicas formas da conquista da liberdade antes da abolição da escravatura: havia também a compra da alforria pelo escravo ou por irmandades católicas. Outra possibilidade era a alforria obtida pela livre vontade do dono do escravo. Na condição de liberto, independentemente de como a liberdade tenha sido adquirida, o escravo poderia deixar a fazenda ou permanecer realizando ou não o mesmo trabalho que fizera ao longo dos anos, com um diferencial: recebendo remuneração pela atividade exercida (RIBEIRO, 2010). Se o escravo deixasse a fazenda, poderia buscar trabalho na cidade, ocupando o ofício aprendido: carpinteiro, pedreiro, alfaiate etc. Apesar de difíceis, as negociações com a sociedade estavam se desenvolvendo e os negros libertos estabeleciam-se e mantinham-se com a remuneração recebida pelo trabalho realizado (JESUS, 2004).

Desde o período escravocrata, em que o senhor da fazenda era responsável pela manutenção dos escravos, a apresentação dos cantos e danças negros era tolerada pelos brancos que organizavam as festas dos santos. Considerada exótica e divertida, a arte do povo negro também era vista como algo simplório e inferior, mas mantida na festividade para que os escravos não se revoltassem contra os senhores de engenho. Esse era um dos poucos momentos em que os negros eram vistos na sala de visitas da casa grande, não como servis, diretamente, mas como atração. (JESUS, 2004).

Ao longo do tempo, os cantos negros que antecediam a festa dos senhores avolumaram-se e o momento da apresentação na festa católica foi modificado. Se antes os cantos abriam as comemorações na fazenda, na cidade passou a fechá-las, ocupando a frente ou os fundos da Igreja do santo homenageado. No festejo negro, a dança e o ritmo eram muito próximos daquilo que os africanos e seus descendentes realizavam nas fazendas: o ritmo era ditado pelo tambu, ou pelo bumbo, as danças eram variadas - na maioria delas havia a umbigada, considerada sensual e até ofensiva pelos mais conservadores, uma vez que, durante a dança, o ventre de homens e mulheres era usado como ponto de contato (JESUS, 2004).

De acordo com Ulhôa (2007), a música brasileira tem suas origens no lundu, ritmo trazido ao Brasil junto aos escravos angolanos. O samba parece ser o resultado da união do lundu com ritmos europeus. Os outros ritmos brasileiros seriam resultados do encontro dessas matrizes: africana e europeia. Segundo Marcílio (2009), o lundu era acompanhado de uma 
dança executada por pares cujos corpos encontravam-se, entrelaçavam-se e a umbigada era um dos elementos da coreografia sensual e lasciva.

Um dos ritmos que originou o samba não foi criado ou desenvolvido nas festas católicas: ele foi trazido pelos povos africanos, nos porões dos navios negreiros, diretamente da África e foi mantido pelos descendentes africanos na senzala. Esse ritmo era apresentado para o público durante as festas católicas, nas fazendas do interior ou no átrio das igrejas nas cidades (LOPES, 2006: JESUS, 2004).

Não foi possível precisar a origem do samba, mas supõe-se que o surgimento e o desenvolvimento do ritmo teria acontecido durante o período escravista. O ritmo que passou a ser conhecido como samba foi forjado da mistura de ritmos africanos, europeus e indígenas. $\mathrm{O}$ primeiro resultado desta mistura seria o lundu (ULHÔA, 2007). A palavra samba, no dialeto dos quiocos de Angola (um dos povos que compõem a etnia bantu), era um verbo que exprimia uma forma de dança, em que os praticantes batem uns nos outros com o peito (LOPES, 2003).

O desenvolvimento do samba ocorreu desde a chegada dos africanos escravizados, que mantiveram costumes de suas tribos, mesmo presos em senzalas. A musicalidade afrodescendente ultrapassou as paredes da senzala durante o período escravista. Os donos das fazendas, que consideravam o ritmo e a dança extravagantes, permitiam a apresentação dos grupos de escravizados, para evitar descontentamentos e possíveis levantes. (SODRÉ, 1998). O samba, depois que se consolidou como ritmo, teve o ambiente urbano como cenário.

As apresentações dos grupos de afrodescendentes em festas da Igreja Católica começaram ainda no período escravista (JESUS, 2004). A participação negra nas festas religiosas era um atrativo para os fiéis que iam às igrejas reverenciar o santo. A festa negra, que muitos consideram profana, atraía grande público. Em muitas festas, um exemplo é Bom Jesus de Pirapora, apresentado a seguir, a festança era mais lembrada que a reverência ao próprio santo. Quando as manifestações dos negros foram proibidas, a festa católica perdeu admiradores. Em São Paulo, no período anterior ao ciclo do café, as festas dos santos católicos eram, muitas vezes, divertimento especial para os moradores da província e tiveram importância na vi da social e econômico-comercial da população paulistana (JESUS, 2004).

No início do ciclo cafeeiro, a capital paulista ganhou importância como lugar de negociações entre fazendeiros e compradores e passou por um processo de capitalização. As 
negociações realizadas na casa grande da fazenda passaram a ser realizadas na sala do sobrado da burguesia emergente (MOTA, 2003).

O comportamento rural, que acompanhou a população paulistana no início da colonização até o ciclo cafeeiro, deixou de ser reproduzido pelos moradores da capital, que expandia seus limites territoriais e econômicos com a ampliação da entrada de capitais e a chegada de povos provenientes de outras partes do país e do mundo. Esses fatores enfraqueceram as festas católicas, levando-as quase ao desaparecimento (JESUS, 2004).

\subsection{Bom Jesus de Pirapora, Nossa Senhora do Rosário, Igreja dos Enforcados: reuniões do povo negro e locais de apresentação do samba paulistano}

A capital paulista foi criada e desenvolvida por jesuítas, ordem da igreja católica. A cidade se formou em torno de uma sede eclesiástica. Desde o início da colonização do país, até o final do ciclo da mineração, São Paulo passou de povoado para vila e depois tornou-se uma cidade. Apesar dos adensamentos, manteve as características de vila reveladas no modo de agir das pessoas e nos costumes condicionados pelos dogmas e representantes da Igreja. As festas realizadas em comemoração aos santos nas capelas e nas igrejas da cidade eram fontes de diversão dos paulistanos (MOTA, 2003).

Nessas comemorações, a parte divina cabia às celebrações religiosas nas capelas e igrejas. Nos arredores da festa, eram montadas barracas que comercializavam produtos e serviços pelos comerciários e pelas irmandades católicas, que aproveitavam o evento para obter dinheiro para suas obras. As irmandades católicas eram reconhecidas, desde o período escravista, como organizações filantrópicas. Além das irmandades católicas criadas e mantidas por brancos, havia as que eram formadas por negros ou por pardos (BARBOSA, 2010). Esses grupos organizados utilizavam os festejos católicos para arrecadar fundos para comprar a alforria das pessoas escravizadas. Além disso, os fundos arrecadados pela irmandade também auxiliavam o pagamento da moradia onde o liberto e a família dele iriam residir até que fossem encontradas formas de sustento. (JESUS, 2004). No ciclo do café, com o movimento abolicionista e com o aumento do número de libertos, essas irmandades ajudavam as comunidades e tiveram papel importante na manutenção das famílias negras (LOPES, 2005).

Segundo Nei Lopes (2005), o sistema de divisão dos lucros obtidos pelas irmandades era idêntico ao da caçada tribal nos dias de outrora. O resultado da caçada, e no caso da 
arrecadação com a festa, deveria beneficiar todos os membros do grupo, sendo tudo dividido e consumido. Tanto os caçadores, como os não caçadores, recebiam o alimento nada restando para o dia seguinte. Apesar de seguirem as regras da religião católica, essa atitude sugere que a forma de pensar a comunidade, vinda da África ainda não havia se perdido.

Nas festas católicas, além da arrecadação de dinheiro, o espaço físico e temporal era usado como ponto de encontro, de congraçamento e de reunião do povo negro. Esses eram os poucos momentos em que o participante (componente ou não da irmandade) estava livre do olhar do dono da fazenda, podendo se expressar por sua arte, por seu canto, por sua dança (JESUS, 2004).

No ambiente urbano, nos eventos religiosos, os afrodescendentes apresentavam para os demais sua arte, seu canto, sua dança, não apenas para divertir o público, mas como demonstração de que eram dotados de inteligência, que não eram animais, como grande parte da sociedade escravista pensava. Buscavam a aceitação como pessoas com capacidade intelectual e que agiam por vontade própria. Procuravam ser compreendidos como indivíduos, como famílias, como grupos que apesar dos costumes diferentes e da condição a que foram submetidos, eram indivíduos (FERNANDES, 2008).

As artes negras paulistas foram mantidas pelos escravizados nas fazendas de café no interior do Estado de São Paulo. As danças e os cânticos eram acompanhados pelo tambu (instrumento feito com a casca oca de árvore e com couro esticado em uma das extremidades). O ritmo, antes mesmo da palavra, era o que ditava a dança e o canto. A fala, em forma de canto, seguia o ritmo das batidas do tambu e os corpos movimentavam-se obedecendo às batidas (SIMSON, 2007).

Durante o período escravista, muitas festas para santos católicos aconteciam na capital paulista. As festas que tinham maior participação de afrodescendentes eram as realizadas para Nossa Senhora do Rosário, no centro da cidade (hoje no Largo do Paiçandu) e também na igreja dos Enforcados, no bairro da Liberdade. Depois da procissão e da missa, o quintal ou a frente da igreja eram ocupados por afrodescendentes vindos de diferentes locais da cidade, onde se reuniam para rezar, seguindo a tradição católica e depois para divertirem-se com muita dança e canto usados para reverenciar ao sagrado, segundo a tradição africana.Depois que a festa acabava, todos os fiéis voltavam para suas casas (JESUS, 2004).

Uma dessas festas apresentava uma conformação diferente: ela acontecia em uma cidade vizinha à capital paulista, de difícil acesso e durava uma semana. A imagem de Bom 
Jesus de Pirapora foi encontrada por africanos escravizados às margens do rio que mais tarde ficou conhecido como Tietê, ainda no período escravista. A cidade desenvolveu-se como tantas outras cidades do Brasil, a partir de uma capela construída em homenagem ao santo, cuja imagem voltava ao local de encontro, mesmo quando tinha sido levada para a cidade vizinha, Parnaíba. A fama do santo atravessou o Estado e, no mês de agosto, muitos senhores vinham com os familiares e com os escravos que os serviam durante a estada para os festejos. Como a festa durava uma semana, os devotos precisavam ficar hospedados na localidade, menos desenvolvida que a capital da província. Enquanto os senhores das fazendas alugavam casas, os brancos pobres e os sertanejos hospedavam-se às margens do rio Tietê em cabanas improvisadas. Os negros ocupavam dois barracões abandonados, onde tinha havido uma hospedaria para clérigos (MORAES, 1989).

Consoante Olga Von Simson, uma cantiga de Geraldo Filme descreve o depoimento da mãe dele, que para pagar uma promessa, queria que o filho participasse da procissão e fosse batizado na igreja de Pirapora, na festa de Bom Jesus. Geraldo, ainda criança, vestiu-se de anjo, mas não pode participar da festividade porque era negro. A mãe deixou a procissão e encaminhou-se para o barracão onde acontecia a festa negra, com muito canto e dança. A música do cantor e compositor Geraldo Filme intitula-se Batuque de Pirapora:

\footnotetext{
Eu era menino

Mamãe disse: vamos embora

Você vai ser batizado

No samba de Pirapora

Mamãe fez uma promessa

Para me vestir de anjo

Me vestiu de azul-celeste

$\mathrm{Na}$ cabeça um arranjo

Ouviu-se a voz do festeiro

No meio da multidão

Menino preto não sai

Aqui nessa procissão

Mamãe, mulher decidida

Ao santo pediu pediu perdão

Jogou minha asa fora

Me levou pro barracão

Lá no barraco

Tudo era alegria

Nego batia na zabumba

E o boi gemia

Iniciado o neguinho

Num batuque de terreiro

Samba de Piracicaba

Tietê e campineiro

Os bambas da Pauliceia

Não consigo esquecer

Fredericão na zabumba
} 


\author{
Fazia a terra tremer \\ Cresci na roda de bamba \\ No meio da alegria \\ Eunice puxava o ponto \\ Dona Olímpia respondia \\ Sinhá caía na roda \\ Gastando a sua sandália \\ E a poeira levantava \\ Com o vento das sete saias \\ Lá no terreiro \\ Tudo era alegria \\ Nego batia na zabumba \\ E o boi gemia \\ Lá no terreiro \\ Tudo era alegria \\ Nego batia na zabumba \\ E o boi gemia.
}

$\mathrm{Na}$ canção fica claro que o negro participava mas não era integrado ao festejo católico. Mantinha-se à margem da sociedade, mesmo em um momento de "liberdade de expressão". O ideal de branqueamento da sociedade paulista e brasileira parece estar contido nessa canção (FERNANDES, 2008). Na letra, Geraldo Filme nomeia os sambistas moradores da capital que iam até Pirapora do Bom Jesus, reverenciar o santo e fazer samba (MORAES, 1989).

Os barracões de Pirapora de Bom Jesus foram os locais onde se viu a transformação do ritmo africano mantido pelos escravizados no samba paulista e depois no samba paulistano, manifestados nas disputas de versos, danças e cantos, entre os grupos do interior paulista e da capital. No início do século XX, o tambu havia sido substituído pelo bumbo e as evoluções e as cantorias seguiam as batidas do mestre que comandava o grupo. As danças receberam nomes diversos e apresentavam diversidade de coreografias: samba lenço ou samba de lenço, samba de roda, jongo, entre outros. Todos eram derivações e adaptações dos "batuques": nome genérico do conjunto de canto, dança e música produzidos pelos afrodescendentes em que o tambu era o instrumento principal (MORAES, 1989).

Esses sambas apresentados nas festas católicas, não eram reproduções da sonoridade africana. Eram a mistura da sonoridade original com ritmos e sons das bandas militares e das bandas europeias, uma vez que muitos dos tocadores aprenderam a ler partitura com mestres italianos, principalmente (MORAES, 1989). O samba paulista difere do samba carioca. Enquanto o primeiro tem menor número de influências, o segundo foi exposto a mais ritmos.

O som era acompanhado por danças, em que se reproduzia a maneira original de sambar: as evoluções eram feitas aos pares ou em fileiras. Por fim, batia-se ventre contra ventre, peito contra peito, perna contra perna, desafiava-se ou convidava-se o parceiro ou a 
parceira para a dança (SODRÉ, 1998). A palavra "samba", em dialeto quioco, também significa "brincar como um cabrito, aos pulos, terminando com a umbigada".

Cada uma das formas de se cantar e dançar samba apresentadas nos barracões de Pirapora tinha um organizador, que tocava o bumbo, puxava o verso e mantinha a ritmo durante a apresentação. Essa pessoa, geralmente, tinha nascido durante os tempos de escravidão na fazenda, quando o dono dos escravos, aproveitando a habilidade discursiva de algum escravizado, apostava nele em disputas de versos contra escravizados de outras fazendas - algo que se assemelhava às apostas nos galos de briga (JESUS, 2004).

Após o final do período escravista, grandes concentrações do povo negro seguiam para a festa de Pirapora do Bom Jesus, mantendo a tradição de dançar e cantar, cultivada desde a África. As trupes, formadas principalmente por afrodescendentes, partiam de cidades do interior de São Paulo, como Campinas e Itu. O principal grupo da capital, que partia da Barra Funda, era organizado por Dionísio Barbosa (SIMSON, 2007).

Essas cidades reuniam muitos libertos porque eram próximas às antigas e prósperas fazendas escravistas, onde existiam oportunidades de trabalho. Nesses lugares, os negros buscavam sustento com ganhos obtidos no trabalho para os fazendeiros ou em atividades das estradas de ferro, dos serviços domésticos ou no comércio ambulante de alimentos (SIMSON, 2007).

A principal característica do samba paulistano é ter nascido nos grupos do interior do Estado, onde o costume e a tradição de reunir-se e fazer batuque era mais constante que na capital da província e o número de negros escravizados era pequeno em relação à população da cidade. As comunidades negras no interior do Estado eram maiores porque grande quantidade de escravizados foi para as diversas fazendas em cidades pequenas ou recémfundadas para trabalhar nas lavouras de café. O batuque feito em dias de festa era uma das formas das comunidades negras manterem-se unidas e de não deixarem suas tradições e costumes perderem-se (FERNANDES, 2008).

Edson Roberto de Jesus (2004), citando Geraldo Filme, compositor e cantor de sambas na Vai-Vai, na Lavapés e no Paulistano da Glória, comenta que a origem do samba paulistano não é tão relacionado à religião africana, mas às festas religiosas católicas. Esse comentário revela a importância dos festejos católicos como espaços de apresentação do produto cultural dos afrodescendentes. O espaço onde os afrodescendentes buscavam a aceitação foi tão 
importante para o samba, quanto a origem rítmica africana, colocada à margem nas palavras de Geraldo Filme.

No final do século XIX e início do século XX, as festas para os santos católicos, desenvolvidas na capital e no interior do Estado, seguiam o calendário religioso católico das datas fixas das comemorações em homenagem aos santos e das datas não fixas como, por exemplo, a Páscoa (MORAES, 1989). Nesse momento, a capital paulista vivia a novidade do desenvolvimento econômico trazido pelo ciclo do café, mas ainda possuía o ritmo de vida de cidades pequenas do interior (FERNANDES, 2008). As festas católicas eram grandes acontecimentos na capital e, assim como no interior, eram palco de manifestações artísticas, entre elas, os ritmos e danças dos povos negros (MORAES, 1989).

Durante as festas católicas, os afrodescendentes tinham a possibilidade de manifestar suas danças e cânticos em reverência ao santo padroeiro homenageado. Nestas festas, as diversas formas de batuque ensaiadas eram apresentadas. Com o passar do tempo, o bumbo substituiu o tambu como marcador dos passos e dos versos. As comunidades negras do interior do Estado, principalmente, adaptaram e desenvolveram, pouco a pouco, o samba paulistano, que tem característica diferente do samba carioca (JESUS, 2004).

O samba da capital fluminense tem maior influência das religiões de matriz africana, trazidas ao Rio de Janeiro pelas pessoas expulsas da Bahia em virtude das revoluções e rebeliões do século XVIII (LOPES, 2006). Os adeptos das religiões de origem africana, como o candomblé, reuniam-se em afoxés e saiam às ruas, nos dias da folia de Momo. O cortejo seguia o ritmo ditado pelos instrumentos rituais (atabaques, agogôs, entre outros) das religiões, de acordo com o orixá regente de cada afoxé (LODY, 1976).

Esses elementos e as festas de Bom Jesus de Pirapora parecem reforçar os comentários de Geraldo Filme sobre a importância das festas católicas no desenvolvimento do samba, dos cordões e, posteriormente, das escolas de samba. A festa do santo era um espaço livre utilizado por quem quisesse manifestar sua arte.

\subsubsection{Os caiapós}

Tanto Olga Von Simson (2007) como Edson Roberto de Jesus (2005) relembram uma manifestação realizada pelos negros que homenageava os índios: os caiapós. Originalmente a dança, que representava o trabalho do pajé para ressuscitar um pequeno índio que havia sido morto por um homem branco, era encenada nos dias de festa dos santos católicos. Para as 
apresentações, os grupos negros vestiam uma malha grossa de algodão que lhes cobria o corpo e enfeitavam-se com penas. Não havia música, apenas uma marcação rudimentar feita com pés e mãos.

A origem dessa apresentação não foi definida pelos autores Simson e Jesus. Porém, ambos indicaram o grupo indígena caiapó como um dos que mais resistiu à dominação portuguesa. Esse grupo sofreu agruras semelhantes àquelas vividas pelos afrodescendentes e, por esse motivo, os negros homenageavam os primeiros moradores da terra, os primeiros a serem escravizados pelos portugueses. Durante a narrativa dançada, o português, opressor de indígenas e de negros, era vencido depois de intensa batalha. Nessa dramatização, o negro apresentava para a população o sofrimento produzido aos indígenas e aos próprios negros. A dominação sofrida pelos indígenas no Brasil ficava evidente nessas apresentações, já a dominação sofrida pelos negros não era tão explícita, uma vez que as roupas e a narrativa tinham o indígena como ator principal (SIMSON, 2007).

Uma explicação sobre a ausência de representação da história de sofrimento e dominação dos negros foi fornecida por Lopes (2005): entre os negros, havia o costume de reverenciar e cultuar os ancestrais, responsáveis por um legado que deveria ser preservado e rememorado. A dramatização em que o indígena era o principal personagem transformou-se numa forma de reverenciá-lo como ancestral, por serem os primeiros habitantes do Brasil. Os caiapós que resistiram às investidas dos portugueses eram considerados os mais bravos guerreiros das terras paulistanas e deixaram uma história de resistência e luta contra a opressão. Esses indígenas, guerreiros como os negros africanos, eram homenageados pelos afrodescendentes (SIMSON, 2007).

Depois do sofrimento na senzala e das mazelas enfrentadas depois da Abolição, representar a saga dos caiapós era uma maneira dos negros exporem as injustiças sofridas pelos mais fracos, sem ocuparem a posição vítima. Afinal, a elite da sociedade paulistana não entenderia o porquê dos negros apresentarem-se na condição de oprimidos, pois a abolição os tornariam iguais (FERNANDES, 2008).

O samba e a representação dos caiapós foram proibidos. Essas manifestações passaram a acontecer nos dias de Carnaval, quando diferentes formas de festejo eram permitidas em virtude do caráter anárquico da festa, conforme indicado por Damatta (1999). A organização da encenação dava-se como uma procissão-cortejo em que os cordões e, posteriormente, as 
escolas de samba, passaram a seguir. O caiapó, diferentemente do entrudo ${ }^{2}$ ou do desfile dos mascarados $^{3}$, apresentava um tema que era acompanhado. Todos os anos, havia um fio condutor no qual a história era apresentada. O caiapó também parece ter contribuído para o desenvolvimento de uma narrativa, mesmo no interior da anarquia e da liberalidade carnavalescas (JESUS, 2004).

O samba, de forma geral, era dançado em roda com as pessoas olhando para o centro, onde um dos dançarinos demonstrava suas habilidades. Quando cansado ou disposto a dividir a apresentação com alguém, o dançarino aproximava-se de outra pessoa da roda e chamava-a para o centro da roda. A dança na roda se assemelhava à dança do candomblé - uma roda, que gira no sentido anti-horário, serve de espaço para que os orixás, divindades de várias origens étnicas africanas, se manifestassem nos iniciados. As divindades possuíam nomes diferentes, dependendo da origem do grupo: se fosse ketu era chamado orixá, angola era chamado de inquice, e se fosse jeje era nomeado de vodun. A roda demonstrava a unidade da comunidade: não possuía começo nem fim e todos podiam se observar, fossem anciãos ou novatos (SILVA, 1994).

Dentre as especializações do samba, as mais comuns eram: samba de roda, samba de lenço, samba rural e batuque. No samba de roda as pessoas dançaram com as mãos apoiadas na cintura ou nos ombros, os homens formavam a roda e depois, as mulheres se intercalavam entre eles. No samba de lenço, ou samba-lenço, as pessoas dançaram com um lenço nas mãos e o usaram para chamar o parceiro com quem queriam dançar. Nesse tipo de samba, formaram-se filas que ficaram frente a frente: os componentes de uma das fileiras dirigiam-se até a outra fila, convidando-os para a dança. No samba rural, também formavam-se duas fileiras: uma com os homens que tocavam instrumentos e outra com os dançarinos (LOPES, 2003). Quando os primeiros avançavam, a segunda fila recuava. Quando a segunda fila avançava, a primeira recuava. O jongo era dançado ao redor dos tocadores que ficavam no centro da roda. No batuque, que nomeava um ritmo e também uma dança, a umbigada era o destaque. Ela era elaborada em um terreno com declive, para que a batida fosse realizada com

\footnotetext{
${ }^{2} \mathrm{O}$ entrudo foi a primeira manifestação carnavalesca vivenciada em terras brasileiras. Tratava-se de um grupo de pessoas que saia às ruas, com ou sem acompanhamento musical, com ou sem fantasias e cuja diversão principal era sujar ou molhar as demais pessoas (JESUS, 2004).

3 O baile de mascarados era um festejo carnavalesco importado da Europa pela alta sociedade brasileira, começando pela carioca. O baile de mascarados realizado pelas grandes sociedades carnavalescas, distinguia ricos e pobres no período carnavalesco (FERREIRA, 2004).
} 
maior precisão e os dançantes lançavam as costas para trás para que o ventre ficasse livre e a batida fosse certeira (JESUS, 2004).

O caráter sensual das danças apresentada pelos negros passou a incomodar os responsáveis pelas festas católicas, o que acarretou a proibição das manifestações da comunidade negra. Em muitas festas católicas, a saída dos negros levou à extinção da festividade, tendo em vista que, mais do que o santo, os romeiros iam buscar de diversão. A proibição dos eventos pagãos acarretou a perda de fiéis nos eventos religiosos e, no caso de Pirapora do Bom Jesus, a festa foi esvaziou-se a partir da década de 1930 (JESUS, 2004).

\subsection{A imigração e os seus efeitos sobre as comunidades negras e sobre o samba}

Pouco antes da abolição do regime escravista, no final do século XIX, iniciou-se o período de imigração de europeus para o Brasil. Fosse por meio da iniciativa privada, como na fazenda Vergueiro, na região onde hoje fica a cidade de Limeira, no interior paulista, fosse pelo governo da província e depois do Estado, milhares de imigrantes chegaram ao Brasil e ocuparam o lugar dos negros escravizados nas lavouras. Depois da abolição, os fazendeiros não queriam negociar com os negros libertos (MENDES, 2009) e, em vez de lhes dar um salário pelo trabalho que faziam, passaram a pagar para os imigrantes (FERNANDES, 2008).

A chegada dos imigrantes tirou o poder de negociação que os libertos tinham conquistado nos momentos iniciais após o fim da escravidão, quando não havia imigrantes europeus para auxiliar a colheita do café. Durante um curto período, os libertos viveram como assalariados (JESUS, 2004).

Florestan Fernandes (2008) e Guerreiro Ramos (1957) pesquisaram o motivo que levou a iniciativa privada e as esferas do governo a trazer da Europa grupos de imigrantes. Os dois autores indicam que a aristocracia do país, no final do século XIX, acreditava que o branqueamento da população auxiliaria o desenvolvimento do país. Essas crenças consideravam que os europeus, cuja cultura e a forma de viver eram exemplos hegemônicos a serem seguidos, permitiriam um desenvolvimento econômico do Brasil sem precedentes. Nessa proposta, não se considerava que parte da responsabilidade da ausência de desenvolvimento no país era advinda da estruturação econômica, baseada na monocultura.

A chegada dos europeus nas lavouras de cafés fez com que os possíveis postos de trabalho criados durante o fim da escravidão, bem como as moradias, fossem preenchidos pelos imigrantes. Nesse sentido, a liberdade retirou os poucos cuidados fornecidos pelos 
senhores de engenho (FERNANDES, 2008). Além disso, a imigração restringiu a possibilidade do negro atuar como vendedor ambulante ou em pequenas quitandas, fosse como marceneiro, alfaiate ou ferreiro, nas pequenas cidades. Então, a ausência de trabalho fez com que os negros se deslocassem para as cidades maiores e, por fim, para a capital paulista (FERNANDES, 2008).

Aos poucos, os imigrantes que foram enviados às fazendas, dirigiram-se à capital do Estado, em virtude do final dos contratos ou pela inaptidão ao trabalho pesado oferecido para eles. Dessa maneira, os imigrantes ocuparam mais uma vez o espaço dos escravos libertos banidos das fazendas após o fim do período escravista, restando ao negro os serviços domésticos, os trabalhos pesados e os subempregos (JESUS, 2004).

Até as casas ocupadas pelos negros, pouco valorizadas no princípio, passaram a ser valorizadas com o aumento da procura pelos imigrantes. Os aluguéis foram aumentados e a tarefa de pagá-los tornou-se quase impossível para quem não tinha emprego, ou recebia pouco e de maneira inconstante. Os negros foram expulsos das regiões valorizadas, encaminhandose para regiões desvalorizadas da capital, onde podiam pagar os aluguéis: lugares alagadiços, terrenos inclinados e sem infraestrutura, próximos ao centro da cidade. Nesses bairros, formaram-se grandes redutos negros na capital paulista (JESUS, 2004). Até o início do século $\mathrm{XX}$, as regiões da cidade que eram ocupadas pelos negros eram a Barra Funda, a Bela Vista e a Liberdade. Em todas elas, o valor dos aluguéis inferior àqueles da região central da cidade. Nas cercanias das três regiões, havia casarões que eram fonte de renda da população negra (SIMSON, 2007).

A expressão cultural, em especial a musical, também era desigual. Os intérpretes de músicas internacionais eram valorizados frente aos cantores de música brasileira, principalmente, em relação àqueles que cantavam samba. As músicas italianas eram as mais ouvidas e valorizadas em virtude do grande número de imigrantes italianos na capital paulista. O estudo feito por Moraes (1989) sobre as sonoridades paulistanas, propôs que a música italiana influenciou o samba paulistano. Moraes sugere que o tom usado no samba paulistano, no final do século XIX e início do século XX, corresponde ao tom mais alto das músicas italianas, diferente do tom das músicas de origem africana, que apresentava um tom mais baixo. Essa característica fez com que o samba paulistano se tornasse mais animado.

Outra influência sobre o samba paulistano - e sobre carnaval paulistano em especial foi o das bandas. A banda da Força Pública era a mais requisitada da cidade. Ela tocava em 
espaços públicos para a apreciação de toda a população. Nessas apresentações, abertas e em locais públicos, via-se a estratificação da sociedade: os menos abastados cediam seus lugares para os mais abastados. Mas, não era só a banda de origem militar que se apresentava: muitos italianos eram músicos e formaram bandas que alcançaram sucesso junto à população da cidade de São Paulo. A banda militar e as bandas de origem italiana eram convidadas a tocar em festas católicas, onde também aconteciam as apresentações dos cânticos e danças negras. A música italiana, dentro e fora das festas religiosas, trouxe novos elementos que foram incorporados na música negra, constituindo uma sonoridade diferenciada daquela dos grupos negros originais. Esses elementos foram responsáveis pela constituição do som apresentado pelos cordões carnavalescos e depois, pelas escolas de samba paulistanas, que perdura até a atualidade (MORAES, 1994).

O carnaval de rua em São Paulo, segundo Simson (2007), começou muito antes da apresentação do cordão Barra Funda, aproximadamente em 1914. O entrudo, trazido pelos portugueses, tomava as ruas da capital paulista e era brincado por senhores e escravos: enquanto estes usavam seringas com água, aqueles jogavam limões de cheiro.

O crescimento dos rendimentos obtidos com o café, fez com que as classes sociais se distanciassem. Os métodos trazidos pelos portugueses seguiram nas camadas mais pobres e os novos métodos de divertimento, importados da Europa, em especial de Veneza, eram o divertimento dos mais abastados. Enquanto a camada mais empobrecida seguia brincando o carnaval jogando água uns nos outros, os mais abastados divertiam-se em bailes de máscaras ou no desfile do corso (SIMSON, 2007).

Com o final da escravidão e o grande número de negros libertos na capital paulista, uma nova forma de brincar o carnaval foi criada pela população negra: o desfile do cordão carnavalesco. A primeira apresentação ocorreu em 1914, no bairro da Barra Funda, um dos redutos negros da capital paulistana (SIMSON, 2007).

Simson (2007) diz que no início do século XX, o carnaval branco, divertimento das camadas mais abastadas, perdia força e aos poucos foi desaparecendo.

\subsection{Procissões, paradas militares e Carnaval: origens dos cordões e escolas de samba de}

\section{São Paulo}

Os cordões e, posteriormente, as escolas de samba paulistanas, foram gestados e nasceram da união de elementos do samba desenvolvido no interior do Estado, onde ficavam 
as fazendas de café que abrigaram os escravos e eram realizadas as festas religiosas e as apresentações das bandas militares. O samba era reduto da dança, da maneira como o corpo se movimentava. A organização era proveniente das festas religiosas, que organizavam as pessoas em filas para a condução do andor do santo. As bandas militares contribuíram com a rigidez da obediência e o comando dos mais velhos e hierarquicamente mais importantes. $\mathrm{Na}$ formação do carnaval paulistano uniram-se os elementos dos três grupos, aparentemente, desconectados e diferentes (MORAES, 1989) e (JESUS, 2004).

A diferença entre essas três formas de manifestação pública, a procissão, a parada militar e o Carnaval, é apresentada nos estudos de Damatta (1999). A pesquisa feita pelo autor foi desenvolvida com base em dados da cidade do Rio de Janeiro.

A partir das relações estabelecidas na capital do Império e depois da República, Damatta analisou a procissão, a parada militar e o Carnaval. Na comparação feita por ele, cada uma dessas manifestações ocorria em datas especiais - a procissão acontecia nos dias santos, a parada, em datas cívicas e a mesma especificidade se aplicava ao Carnaval - e acontecia por razões diversas. Cada uma delas homenageava um fato importante: na procissão, a vida e as realizações do santo eram lembradas e reverenciadas, na parada militar, recordavam-se as batalhas bem sucedidas e as vitórias dos mártires e heróis e, no Carnaval, comemorava-se a alegria, a troca de papéis e a redução da repressão. O ponto comum apresentado pelo autor era o fato dessas manifestações ocorrerem na rua. Porém, enquanto nas procissões e no Carnaval todos participavam, na parada o acesso era restrito e apenas o elemento militar era o centro das atenções a ser observado pelo público..A parada militar era a manifestação mais rígida e uniforme, acontecia em apenas um sentido e obedecia a padrões e regras preestabelecidas. Todos usavam fardas iguais e ostentavam patentes, de acordo com o grupo a que pertenciam: as posições ocupadas revelavam a estratificação da estrutura. Símbolos, medalhas, faixas e fardas, eram usados para diferenciar os militares. Percebe-se que as posições eram fortemente marcadas.

Na procissão, as posições também eram marcadas, no entanto, o destaque era do santo. Abaixo dele, seguia o líder religioso responsável por conduzir a procissão: padre, bispo etc. Depois, estavam os demais integrantes da igreja, outros padres e freiras e pessoas que eram consagradas, mas não ordenadas, que não passaram pelo convento ou pelo seminário (aqueles que auxiliavam a realização dos eventos da Igreja). As roupas diferenciavam as pessoas: os componentes do clero usavam roupas de cerimônia, assim como os ajudantes. O público, que 
participava da cerimônia pública e ao ar livre respondendo às cantigas, às ladainhas e às rezas, vestia-se de anjo ou conforme a classe que pertenciam. Rumavam em apenas uma direção, ponto de partida e de chegada preestabelecidos (DAMATTA, 1989).

No Carnaval, analisado por Damatta, não havia uma ordem a ser seguida. O público tornava-se integrante da festa e fazia com que ela acontecesse. As inversões eram conscientemente permitidas e desejadas. Não havia ordenamento no espaço e as pessoas podiam se vestir como quisessem e ser o que quisessem. O pobre poderia se tornar rico e o rico fingir-se de pobre. Era um período em que as regras de conduta da sociedade eram afrouxadas ou até suprimidas (DAMATTA, 1989).

Não se sabe a origem dessa festa. A versão mais aceita propõe que a palavra Carnaval significaria "festa da carne" e ocorria antes do mais extenso período de penitência dentro do calendário católico: a Quaresma. Além de determinar o período de acontecimento do Carnaval, a Quaresma prescrevia o que deveria ocorrer antes dela: o excesso e o exagero. Em Moraes (2009), o autor aponta que, de maneira semelhante às celebrações do deus grego Baco (ou sua versão romanizada, Dionísio) - em que os devotos cultuavam e festejavam o deus, entregavam-se ao excesso da bebida, da comida, do sexo - os excessos e as inversões faziam parte do cortejo do Carnaval. A penitência exigida durante a Quaresma era em relação ao sexo. Dessa maneira, no período carnavalesco, os excessos e exageros, como os festejos a Dionísio, eram permitidos e aceitos, uma vez que depois viria um longo período de limitações e penitências (FERREIRA, 2004). Diferentemente dos cristãos, que consideram o prazer como um pecado, os romanos e, anteriormente, os gregos, o consideravam uma maneira de alcançar o divino: deuses eram reverenciados em festas em que o prazer era buscado e obtido por meio de comida, bebida, de discursos, de conversas, de cânticos, de danças e de sexo (MORAES, 2009).

Datas, hábitos e costumes de religiões ditas pagãs foram incorporados durante o desenvolvimento das regras da Igreja Católica para que ocorresse a identificação e permanência dos fiéis. Um exemplo dessa ocorrência é o festejo da Páscoa, que imprimiu o estabelecimento do período do Carnaval, mantendo o princípio do judaísmo da vitória sobre a morte dos que creem em Deus. A data de comemoração, porém, não seguiu o calendário judaico: as datas das celebrações da Páscoa e de Pessach não coincidem. Os cristãos seguiram o calendário de religiões pagãs para determinar a sua Páscoa: a primeira lua cheia depois do 
solstício de verão no hemisfério Norte corresponde à sexta-feira santa; no domingo comemora-se a Páscoa.

No caso de São Paulo as paradas militares, as procissões e o Carnaval contribuíram para a formação dos cordões e posteriormente das escolas de samba. Das procissões e das paradas foi herdada a forma do desfile: sempre em frente, em progressão. Da procissão e da parada vieram o canto e a sonoridade, cuja base era o samba e os elementos agregados eram os cantos católicos e o ritmo da marcha. Do carnaval de rua foi herdado o improviso, a liberdade, a permissão, a comemoração. Do carnaval de salão, os bailes da alta sociedade e as exibições dos mascarados foram herdados o modo de brincar o carnaval importado da Itália uma tentativa de civilizar o povo que gostava do entrudo, em que farinha, água e outros elementos eram atirados pelas pessoas umas nas outras - e as fantasias elaboradas (FERREIRA, 2004).

Mais comuns no interior do país e no nordeste, os elementos do maracatu, como o rei e a rainha, encontrados na formação dos primeiros cordões, também auxiliaram a formação dos cordões carnavalescos paulistanos. Sodré (1998) e Ferreira (2004) sugerem que o maracatu e o afoxé são formadores do carnaval carioca, mas nas pesquisas desenvolvidas por Moraes (1989), Jesus (2004), Simson (2007), que enfocaram o Carnaval da capital paulista, essas manifestações não foram citadas. Assim, ainda restam dúvidas sobre o fato de tais manifestações terem fornecido elementos para o desenvolvimento do carnaval negro de São Paulo. Sabe-se que tanto o maracatu como o afoxé eram expressões da religiosidade do povo negro (LODY, 1976; PRAZERES, 2012). Apesar de não serem citados claramente pelos pesquisadores do carnaval paulistano, alguns dos fundadores dos cordões carnavalescos de São Paulo tinham forte ligação com as religiões de matriz africana. Deolinda Madre, a Madrinha Eunice, fundadora da escola de samba Lavapés, foi sacerdotisa no culto aos orixás (ARAÚJO, 2012). Os elementos de sopro, afinados com a musicalidade europeia, em especial a italiana, eram permitidos nos cordões carnavalescos. Assim como no afoxé, o som dos instrumentos de percussão constituía a base do desfile carnavalesco (MORAES, 1989).

$\mathrm{Na}$ análise feita por Damatta (1989), o carnaval de blocos que acontece até hoje por toda a capital fluminense foi utilizado como fonte de pesquisa. Nessa modalidade carnavalesca, era o folião quem determinava o limite. O desfile do bloco carnavalesco não segue regras, diferentemente do desfile da escola de samba. Não havia competição entre os blocos, apenas a folia e o festejo. Essa era a diferença marcante entre o que Damatta (1989) 
analisou e o que acontecia durante o período de Momo em São Paulo. Enquanto nos blocos, cada um usava da própria criatividade para fantasiar-se, no desfile das escolas de samba, havia um enredo a ser seguido. As fantasias, os carros alegóricos, o samba, as alas, tudo convergia para o estabelecimento de uma narrativa com começo, meio e fim, seguindo o regulamento do desfile das escolas de samba de São Paulo, distribuído pela Ligasp ${ }^{4}$. A obrigação de desenvolver uma história e a rigidez da apresentação da narração, fosse ela verídica ou não, faz com que o desfile da escola de samba, como era vista em São Paulo, se aproximasse da procissão e da parada militar (DAMATTA, 1989).

\subsection{Cordões carnavalescos e escolas de samba}

O crescimento da cidade de São Paulo fez com que os locais pouco valorizados e que se localizavam próximos à região central fossem ocupados pelos imigrantes, cuja remuneração permitia o pagamento de aluguéis mais caros que os negros - desempregados e sem espaço para desenvolver as atividades que lhes geravam renda. Com isso, os casarões das ruas mais próximas ao centro da cidade, que antes abrigavam os negros, passaram a abrigar imigrantes.

\subsubsection{Barra Funda, Bela Vista e Glicério: à margem do centro, berço dos cordões e das escolas de samba paulistanas}

Impedidos de permanecer no centro da capital, os negros deslocaram-se para locais mais afastados e desvalorizados: terrenos desnivelados e próximos aos rios com alagamentos constantes. Esses locais também eram de difícil acesso, exigiam longas caminhadas e transposição de rios e córregos até às ruas centrais (SIMSON, 2007).

Grande parte dos negros que viviam na capital, além daqueles que vinham do interior, mudou-se para esses locais. Apesar de tais locais fazerem parte do centro da cidade atualmente, à época esses bairros estavam à margem da cidade, em virtude da presença de rios ou da falta de infraestrutura. Porém, muitos dos afrodescendentes tinham experimentado vivências sub-humanas e viver nesses bairros era igual ou melhor do que nas senzalas das fazendas. Apesar das dificuldades, havia a liberdade de ir e vir (SIMSON, 2007).

\footnotetext{
${ }^{4}$ Dados disponíveis em: <www.ligasp.com.br/>. Acesso em: 2 nov. 2013.
} 
Esses bairros estavam longe do centro - possível fonte de renda - mas, estavam perto de casarões de ricos fazendeiros, onde as mulheres podiam realizar afazeres domésticos, atividade que as imigrantes não aceitavam exercer. Outra atividade que gerava empregos aos homens era a estrada de ferro (JESUS, 2004).

Barra Funda, Bexiga (Bela Vista) e Glicério foram os bairros que receberam as populações negras. As afrodescendentes trabalhavam nos casarões do bairro da Liberdade, nos casarões da Avenida Paulista e nos casarões dos Campos Elíseos. Os homens trabalhavam como carregadores na estrada de ferro, que possuía no largo da Banana, um importante entreposto (SIMSON, 2007).

Tendo uma fonte de renda, mesmo que por meio de um subemprego, as famílias negras conseguiram permanecer nesses bairros e neles constituíam forte presença. Mesmo no bairro da Bela Vista, que fora um quilombo e depois da Abolição recebeu muitos imigrantes, a presença negra era marcante.

Nesses três bairros nasceram as primeiras manifestações carnavalescas paulistas, tendo o samba como base. Em 1914, saiu às ruas o Cordão Barra Funda, cujos componentes vestiam calças brancas e camisas verdes. O criador e mentor do grupo era o marceneiro Dionísio Barboza, que aprendera o ofício com o pai. Em virtude da profissão, Dionísio foi trabalhar no Rio de Janeiro. Na capital da República, ele teve contato com sambistas cariocas, participou de ensaios e desfiles dos ranchos e das primeiras escolas de samba e assistiu aos desfiles militares. Além desta vivência, Dionísio era frequentador contumaz das festas de Bom Jesus da Pirapora, onde o samba paulista dava os primeiros passos. Essa bagagem e a ajuda de amigos e familiares permitiu a criação do cordão da Barra Funda. Devido à pequena quantidade de pessoas, o grupo saiu basicamente tocando pandeiros e chocalhos confeccionados com tampinhas de garrafas. Aos poucos, recebeu novos integrantes até o desfile de 1920, quando desfilou com 70 pessoas. Nesse ano, o número de instrumentos tocados era maior e pertenciam aos participantes, não ao cordão (SIMSON, 2007).

Desde o início, o grupo apresentava-se cantando músicas de própria autoria, tendo como ritmo a marcha-sambada, que juntava o toque das bandas militares e o suingue do samba paulistano - forjado no interior do estado onde a maioria dos negros vivia. O cordão contava com um grupo que tocava instrumentos de sopro que, durante as pausas do grupo da percussão parava de tocar. Os instrumentos de sopro eram tocados por integrantes que liam partituras e tocavam em bandas, militares ou de origem italiana. Para fazer parte dos grupos 
musicais dos cordões carnavalescos era necessário passar por testes que avaliavam a leitura de partituras e a boa performance com o instrumento. Os dirigentes preferiam ter menos componentes no grupo em vez de ensinar novos integrantes a tocar (SIMSON, 2007).

O grupo do bairro não se reunia apenas para desfilar no Carnaval. Na Barra Funda do início do século $\mathrm{XX}$, o cordão proporcionava diversão para a população negra durante o ano todo. A sede do grupo era a casa de Dionísio Barboza, na rua Vitorino Camilo, mas, uma vez por mês, eram realizados bailes em espaços alugados. Os bailes eram animados pela banda de instrumentos de sopro que tocava sem remuneração e auxiliava a obtenção de fundos para o desfile, trazendo diversão para os moradores do bairro. Nestes bailes, não era autorizada a entrada de pessoas descalças. O cumprimento dessa regra era realizado por um grupo de seguranças formado pelos homens mais fortes e corajosos do bairro, trabalhadores da estiva no largo da Banana.

O grupo Barra Funda era um centro de diversão para a população negra e pobre que vivia nas redondezas, um centro de manutenção cultural e social que, mesmo sem interesse ou consciência, assumiu essa responsabilidade. O cordão Barra Funda integrou a comunidade por meio da preservação dos costumes e tradições negras, valorizando as formas de viver e vivenciar o mundo das famílias negras (SIMSON, 2007).

Em 1918, surgiu outro cordão carnavalesco na Barra Funda: o Campos Elíseos. Ele era formado por negros um pouco mais abastados e que se apresentavam com melhores trajes. Em pouco tempo, o Campos Elíseos tornou-se o principal adversário do cordão da Barra Funda. Além dos elementos que compunham o Barra Funda, o Campos Elíseos introduziu a bandeira e o porta-bandeira no desfile, mesmo que ela não viesse acompanhada de um mestresala. Eles apresentavam-se tocando marcha, diferentemente da marcha-sambada do cordão da Barra Funda. O cordão criado por Dionísio Barboza desapareceu na década de 1940, mas ressurgiu em 1953, e perdura até os dias atuais, tendo como criador Inocêncio Mulata. Seu apogeu como escola de samba ocorreu nas décadas de 1970 e 1980, sob a direção administrativa do filho de Inocêncio Mulata, Carlos Tobias. Neste período ganhou 11 títulos na disputa entre as escolas de samba no carnaval paulistano ${ }^{5}$.

Na Bela Vista, também conhecida como Bexiga, outro cordão fez parte da história do início do samba paulistano. No bairro, antes do desenvolvimento promovido pelo ciclo do

\footnotetext{
${ }^{5}$ Dados disponíveis em: <www.ligasp.com.br/>. Acesso em: 2 nov. 2013.
} 
café, existiu um quilombo, lugar de refúgio para escravos da capital e arredores. Apesar de ficar perto da região central da cidade, o acesso era dificultado pelo córrego da Saracura, que isolava a Bela Vista do restante da cidade. Com o fim do período escravista e a chegada dos imigrantes, principalmente dos italianos, a Bela Vista foi tomada por estrangeiros, mesmo assim, os negros ainda permaneceram no local. Enquanto os imigrantes, que possuíam melhores condições financeiras, ocuparam as boas casas, os afrodescendentes ficaram com as moradias mais precárias, em locais desnivelados e com menos infraestrutura. (MORAES, 1989).

Entre o final da década de 1920 e o início de 1930, surgiu o cordão Vai-Vai. Especulase sobre a origem e o nome do cordão. A versão mais aceita era que um grupo de penetras foi expulso de uma festa promovida pelo time de futebol Cai-Cai, aos gritos de "vai, vai embora". O grupo expulso criou logo depois um cordão carnavalesco para provocar os integrantes do Cai-Cai, utilizando as cores branca e preta, enquanto as cores do Vai-Vai eram o preto e o branco. O Vai-Vai organizava-se como um cordão, mas apresentou uma novidade: uma mulher conduzia o estandarte da escola. Até então, a atividade era exclusivamente masculina (JESUS, 2004).

A história do desenho da bandeira da escola foi fornecida por Fernando Penteado, filho de Frederico Penteado - um dos fundadores do cordão e idealizador do desenho, durante entrevista concedida no trabalho de campo: a coroa representava a realeza dos negros e o ramo de café homenageava os barões do café, que eram os patrões dos afrodescendentes que moravam na Bela Vista. Mais uma vez, e talvez de maneira inconsciente, a valorização do negro e de seus costumes estava presente no cordão Vai-Vai, exposta no símbolo maior da agremiação.

O entrevistado Fernando Penteado fez apenas uma proposta sobre a representação da coroa como símbolo de realeza. Mas, na congada e no maracatu, dois folguedos de origem negra, que se organizam em forma de cortejo como o desfile de uma escola de samba, existem a figura do rei e da rainha. Tais expressões culturais eram facilmente encontradas: a congada no interior do Estado e o maracatu no nordeste. Como grande parte dos negros que estavam na capital paulista no início do século XX veio do interior do Estado, muitos eram descendentes ou migrantes vindos do Nordeste. É possível supor que a realeza atribuída aos negros da Vai-Vai venha de alguma destas expressões culturais (CEZAR, 2012). 
A Vai-Vai foi a escola de samba que obteve o maior número de vitórias do carnaval paulistano. Desde que deixou de ser cordão carnavalesco para tornar-se escola de samba, em 1972, a Vai-Vai conquistou, até 2012, 14 títulos na disputa entre as escolas de samba paulistanas $^{6}$.

Em 1937, no bairro do Glicério, surgiu a escola de samba Lavapés, cuja origem foi um bloco de mulheres e homens que desfilavam fantasiados com roupas de baianas. A escola foi a primeira a apresentar-se tocando samba (ARAÚJO, 2012). Outra inovação foi ter sido fundada e presidida por muitos anos por uma mulher, Deolinda Madre, conhecida como Madrinha Eunice. Sugere-se que a primazia da mulher nessa agremiação pode ser entendida em virtude da importância da mulher no bairro do Glicério, que ficava perto das mansões do bairro da Liberdade (SIMSON, 2007). Eram as mulheres que sustentavam o lar porque nessa localidade elas tinham mais facilidade de encontrar trabalho como empregas domésticas. $\mathrm{Na}$ Barra Funda e Bexiga, as possibilidades de trabalho eram semelhantes: as mulheres dedicavam-se aos afazeres domésticos e os homens trabalhavam como estivadores na Barra Funda ou para os italianos, na Bela Vista. Entre as escolas citadas, Lavapés é a agremiação que possui a pior classificação atualmente. Desde 1975 ela não desfila entre as grandes do carnaval paulistano. Em 2012, fazia parte do grupo quatro da Uesp e continua existindo devido ao comprometimento dos familiares de Madrinha Eunice, que conseguiram mantê-la em atividade (ARAÚJO, 2012).

Os cordões começaram a perder força com a instituição, em 1968, do primeiro concurso de escolas de samba da capital paulista. O concurso foi solicitado pela Federação de Entidades Carnavalescas, que agregava as maiores escolas de samba e cordões da época e tinha o jornalista Morais Sarmento, como presidente. Essa entidade foi criada durante encontros entre os presidentes de escolas, como a Nenê de Vila Matilde e Lavapés, e de cordões carnavalescos, como Vai-Vai e Camisa Verde (SIMSON, 2007).

O objetivo principal dessa união era obter subvenção da prefeitura para a produção do desfile carnavalesco. O prefeito da cidade, o carioca Faria Lima, gostava de Carnaval e aceitou a proposta. Ele exigiu a realização de uma disputa com regras comuns a todos. Com isso, foi trazido do Rio de Janeiro um regulamento que passou a balizar o carnaval paulista. Havia diferenças entre os dois carnavais e com isso, a hegemonia dos cordões foi perdendo

\footnotetext{
${ }^{6}$ Dados disponíveis em: <www.camisaverde.net/index.html>. Acesso em: 2 nov. 2013.
} 
força, uma vez que o regulamento era feito para escolas de samba. A necessidade de se adequarem às regras levou os dois mais importantes cordões da capital a tornarem-se escolas de samba, em 1972. Com o domínio sobre as regras e com a capacidade de realizar bons desfiles, a Camisa Verde e a Vai-Vai destacaram-se no cenário do carnaval paulistano (SIMSON, 2007).

\subsubsection{A rivalidade entre os cordões: quando a brincadeira era vencida por quem roubava a bandeira da outra agremiação}

A bandeira (ou pavilhão, como era conhecido no carnaval paulista) era o símbolo mais importante da escola de samba. Segundo Fernando Penteado, em entrevista concedida para essa pesquisa, a escola era reconhecida pelo pavilhão. Penteado comentou que o pavilhão de uma escola de samba era o símbolo que identificava e conduzia uma nação, no caso, a nação de admiradores, torcedores e participantes da escola de samba. Ele afirmou que ter um pano como identificador foi uma prática usada pelos africanos escravizados, no período escravista. A avó dele teria lhe dito, que no momento da separação das famílias vendidas aos fazendeiros, vários pedaços das vestes eram rasgados e desenhos simples eram feitos. Cada um os membros ficava com um pedaço, como símbolo da própria origem. Com a abolição, os afrodescendentes libertos saíram em busca de seus familiares usando como referência os desenhos feitos nas vestes e guardados por anos. O pavilhão de uma escola de samba, segundo Penteado, pode ser comparado a tais desenhos, ao agregar pessoas vindas de vários lugares da cidade e de várias classes sociais.

A bandeira foi introduzida nos cordões carnavalescos pelo grupo Campos Elíseos. Ela era trazida por um porta-bandeira, sem a companhia de um mestre-sala. Com o tempo, a rivalidade entre os grupos cresceu e o encontro entre dois cordões tornou-se um evento com forte tensão emocional. A princípio, os pavilhões eram trocados e eram girados no espaço do outro cordão carnavalesco. Com a devolução dos pavilhões aos donos, os integrantes enfrentavam-se para tentar pegar o pavilhão e demonstrar quem era melhor ${ }^{7}$.

Para minimizar a possibilidade de ter o símbolo "tomado" foi criada a figura do mestre-sala. Ele deveria ser o mais ágil, forte e briguento entre os componentes da escola. Deveria girar em torno da porta-bandeira, sempre atento para que ninguém chegasse perto da

\footnotetext{
${ }^{7}$ Dados disponíveis em: <http://www.ligasp.com.br/>. Acesso em: 2 nov. 2013.
} 
bandeira. Caso isso acontecesse, deveria atracar-se com o integrante de outra escola e defender o pavilhão. Com o aumento da violência para defender o pavilhão, os primeiros mestres-salas desfilavam com leques que escondiam navalhas e bastões usados para golpear quem se atrevesse a chegar perto do pavilhão. Aqueles que tentavam levar ou danificar o pavilhão, também vinham armados e eram bons de briga (SIMSON, 2007).

Outro elemento que ajudava a defesa do pavilhão e das mulheres que passaram a integrar os cordões eram os homens que se vestiam de baiana ou de mulher na ala dos esfarrapados. Inocêncio Tobias, fundador da Camisa Verde e Branco, ficou conhecido como Inocêncio Mulata ao ser confundido com uma bela mulher por um dos assistentes de um desfile de bloco dos esfarrapados (SIMSON, 2007).

A rivalidade entre os cordões era grande e as brigas constantes. Durante um período do século XX, os blocos de esfarrapados aguardavam que os confrontos acontecessem nos diversos concursos organizados na cidade, sem que o cordão fosse prejudicado. Os confrontos eram violentos e os integrantes sempre voltavam para casa com algum ferimento em decorrência das pancadas dadas e recebidas. Expurgada a violência, os cordões desfilavam tranquilamente, sem brigas com os integrantes dos outros grupos e sem terem instrumentos e fantasias destruídos (SIMSON, 2007).

Tanta agressividade, comum nas décadas de 1940 e 1950, fez do pavilhão o objeto mais cuidado e cultuado dentro da escola de samba. Os instrumentos, por mais caros que fossem, podiam ser comprados novamente, mas se o pavilhão fosse danificado ou levado, a apresentação do cordão não ocorria. Ter o pavilhão levado era o mesmo que ter a identidade retirada (SIMSON, 2007). O pavilhão esteve sempre à mostra na quadra das escolas e era reverenciado pela comunidade da escola de samba como um símbolo místico, de identidade e identificação.

\subsubsection{As partes de uma escola de samba}

No Carnaval de 2012, as escolas de samba foram avaliadas durante o desfile carnavalesco, em nove quesitos, segundo o regulamento discutido, votado e aprovado pelos presidentes das escolas que faziam parte da Liga Independente das Escolas de Samba de São Paulo. Segundo o regulamento usado para o Carnaval de 2012, os quesitos julgados foram: 
comissão de frente, mestre-sala e porta-bandeira, alegoria, fantasia, enredo, samba enredo, bateria, harmonia e evolução ${ }^{8}$.

Tendo em vista que julgamento era feito por setores, as escolas de sambas dividiramse em departamentos para que funções específicas fossem realizadas seguindo as regras estabelecidas pelos critérios de julgamento, também votados e aceitos pelos presidentes das escolas de samba. A setorização da escola foi verificada durante o trabalho de campo dessa pesquisa. Essa divisão também foi descrita por Tureta (2011), que acompanhou a organização do setor da harmonia da escola de samba Vai-Vai.

A especialização permitiu que a atividade fosse aprimorada: em vez de treinar todos os componentes da escola de samba para todas as atividades desenvolvidas na escola, treinava-se para a ação em setores determinados. Assim, a escola ensinava ritmistas para atuar na bateria e não para dançar como passistas, mestres-salas ou porta-bandeiras. $\mathrm{O}$ integrante que tinha a função definida dirigia sua atenção para uma única atividade (TURETA, 2011).

Os ritmistas eram responsáveis pela bateria. A fantasia era de responsabilidade das costureiras que se baseavam nos desenhos feitos pelo carnavalesco. As alegorias eram construídas pelos marceneiros, serralheiros, escultores, pintores que se fundamentavam nos desenhos desenvolvidos pelo carnavalesco. O puxador e os compositores eram responsáveis pelo quesito samba-enredo, julgado de acordo com a adequação da música ao enredo contado pela escola. O enredo, do carnavalesco, na determinação da ordem do desfile e de organização na montagem da escola. A harmonia e evolução, dos harmonias, mestre-sala e porta-bandeira, do primeiro casal da escola. E a comissão de frente era responsabilidade do grupo que a compõe.

\subsection{Cenário da pesquisa}

A delimitação da pesquisa foi elaborada a partir da contextualização histórica desenvolvida nas seções anteriores. Verificou-se que os elementos das escolas de samba paulistanas têm origem na cultura afro-brasileira, preservada nas fazendas de monocultura, durante o período escravista. Em São Paulo, essas manifestações concentravam-se nas cidades do interior, uma vez que a capital paulista, até o ciclo do café, era uma província acanhada, com reduzida população e pouca incidência de escravos. O samba paulistano era apresentado

\footnotetext{
${ }^{8}$ Dados disponíveis em: <www.ligasp.com.br/>. Acesso em: 2 nov. 2013.
} 
durante eventos religiosos e que, sofreu influências dos imigrantes, principalmente os italianos.

O fim do período escravista levou a população negra a viver em condições muito próximas da vida cativa, uma vez que as vagas de trabalho foram assumidas pelos imigrantes, permanecendo os libertos em situação marginal. Foi necessário o apadrinhamento de um homem público, para que a primeira entidade representativa dos cordões e das escolas de sambas fosse aceita pelo poder público. Depois de aceita e reconhecida, as agremiações carnavalescas tiveram que se adequar à norma do poder público que fez desaparecer a mais tradicional manifestação carnavalesca paulistana, o cordão, dando espaço ao crescimento das escolas de samba paulistanas. 


\title{
Capítulo 2: Identidade e escola de samba
}

\author{
E é prá chegar sabendo que a gente tem o sol na mão \\ E o brilho das pessoas é bem maior, irá iluminar nossas manhãs \\ Vamos levar o samba com união, no pique de uma escola campeã \\ Não vamos deixar ninguém atrapalhar a nossa passagem \\ Não vamos deixar ninguém chegar com sacanagem \\ Vão'bora que a hora é essa e vamos ganhar \\ Não vamos deixar uns e outros melar \\ Gonzaguinha, O homem falou
}

Neste capítulo, serão discutidas: a identidade, suas formas e como ela age sobre o indivíduo. Segundo os estudos efetuados por Axel Honneth e de Nancy Fraser sobre o reconhecimento, serão discutidos os itens que levaram à formação da identidade da pessoa no grupo no interior das escolas de samba do Carnaval da cidade de São Paulo.

Honneth (2003) expõe que a consciência de integração a um grupo é percebido quando se tem a manifestação de um desrespeito. Combater a ofensa sofrida por um participante é uma forma de desenvolver os laços de identificação entre o sujeito e o grupo e vice-versa, o grupo com o mundo e o sujeito com ele mesmo, dentro do grupo. Ele divide as formas de reconhecimento em três: familiar, jurídica e autorreconhecimento.

Fraser (2011) ampliou as considerações de Honetth propondo que o autorreconhecimento do ser humano não é uma questão de mérito, mas uma questão de justiça social. A autora expõe que o reconhecimento e a redistribuição monetária andam juntos e indica que o ser humano pode ser identificado por mais de um aspecto e que ele pode ser reconhecido em mais de um grupo.

Os estudos dos dois teóricos citados foi aplicado aos eventos históricos do final do século XIX, quando o afrodescendente, apesar de liberto, era considerado um ser inferior pelas elites brasileiras. O final da escravidão, porém, permitiu que o afrodescendente fosse inserido em outros grupos da sociedade, além do grupo formado nos tempos da senzala (FERNANDES, 2008).

As ações, conflitos e reflexões sobre a vida em grupo pelos afrodescendentes que anteriormente não poderiam ser manifestados ou expressados permitiram uma vivência inédita para quem teve os laços familiares perdidos: a possibilidade de ser reconhecido e de reconhecer a si mesmo (HONNETH, 2003).

O movimento das escolas de samba na capital paulista surgiu no início do século XX, com o êxodo de libertos das fazendas cafeeiras, devido à entrega dos postos de trabalho que ocupavam para os imigrantes estrangeiros (MENDES, 2009). 
Fernandes (2008), pesquisador das Ciências Sociais e Ramos (1957), estudioso da Psicanálise, propõem uma explicação para o desrespeito sofrido pela população negra que, por mais de 300 anos sob a escravidão, exerceu as funções designadas pelos vários ciclos de monocultura no Brasil. Os autores expuseram que a população negra foi vítima de teorias iniciadas por Nina Rodrigues, do final do século XIX, que desvalorizavam a figura do negro escravizado, acentuando os caracteres negativos da personalidade e do comportamento e reforçando que o trabalho da população negra escravizada não era necessário para o desenvolvimento buscado pelo Brasil (RAMOS, 1957).

No início da colonização do Brasil foi possível observar que a escravidão africana substituiu a indígena, que não se adaptara ao trabalho pesado e recebia castigos decorrentes da realização insatisfatória (ou da não realização) das atividades determinadas (FERNANDES, 2008).

O africano escravizado vivia sob as mesmas regras rígidas impostas aos silvícolas. Enquanto os indígenas, moradores e conhecedores das terras ao redor das fazendas fugiam com êxito, os africanos, mesmo sofrendo castigos, não tinham para onde fugir (FERNANDES, 2008).

A igreja católica dizia que o ser humano tinha alma. A escravidão, tanto de indígenas, quanto de africanos, era aceita porque acreditava-se que nenhum dos dois grupos possuísse alma. Não tendo, passando-se à condição de coisa, podia ser escravizado (FERNANDES, 2008). A coisificação do negro perdurou no discurso dos donos das fazendas por todo o período escravista. Esse discurso foi mantido inclusive depois do fim do período escravista, como indicam os estudos realizados por Nina Rodrigues no final do século XIX. O autor realizou estudos sobre os pacientes de manicômios da época e verificou que havia um grande número de afrodescendentes internados. Os conceitos desenvolvidos por Nina Rodrigues, carregados dos preconceitos da época, serviram de base para que os fazendeiros desqualificassem ainda mais a presença afrodescendente nas fazendas (RAMOS, 1957; MENDES, 2009).

Embasados nas ideias de Nina Rodrigues, os fazendeiros passaram a incorporar o movimento abolicionista objetivando livrar-se de um grupo que ficou cada vez oneroso e totalmente dependente do seu dono (FERNANDES, 2008). 
O fim do período escravista também foi um desrespeito ao povo negro: a liberdade lhe foi concedida, mas não foi desenvolvido nenhum plano de integração dos libertos aos postos de trabalho, à educação ou à moradia (FERNANDES, 2008).

A teoria do branqueamento, citada tanto por Fernandes (2008) como por Ramos (1957), desqualificava o afrodescendente para o exercício de qualquer tipo de atividade, mesmo que anteriormente a ação tivesse sido realizada pelo negro escravizado.

Esta substituição compulsiva, incentivada por governantes e seguida pelos donos das fazendas de café, poderia ser entendida como mais um desrespeito ao modo de vida que as populações negras escravizadas possuíam. Mesmo vivendo sobre a mão forte dos senhores de escravos, sob toda sorte de castigos, as populações negras escravizadas trabalhavam e, subsidiadas pelo fazendeiro, tinham o alimento e a moradia (MENDES, 2009).

Com a chegada dos imigrantes e a retirada (ou saída) dos libertos das fazendas, nem mesmo a alimentação estava assegurada. Foi neste ambiente de incertezas que surgiram os primeiros cordões carnavalescos de São Paulo (SIMSON, 2007).

\subsection{Os tipos de reconhecimento}

Axel Honneth (2003) discutiu, criticou e aprofundou os estudos de Hegel e Mead sobre os modelos de reconhecimento. Honneth expõe que esses autores sugeriram, mas não esclareceram ou aprofundaram, os modelos que formularam. Por meio da crítica feita aos escritos hegelianos e de Mead, Honneth desenvolveu seus modelos de reconhecimento.

Consoante Honneth (2003), a vivência em sociedade, em uma relação de intersubjetividade, leva ao reconhecimento. O reconhecer-se como ser social vem, comumente, pelos conflitos, que podem ser privados ou públicos. Os conflitos atingem cada um dos sujeitos de modo particular, assim como o reconhecimento de cada indivíduo é particular para ele e para quem o reconhece.

O autor propõe que o primeiro tipo de reconhecimento ocorre no seio familiar: o reconhecimento pelo amor e pelo afeto. Honneth exemplifica o primeiro tipo de reconhecimento a partir do novo membro da família, o bebê, que se reconhece e é reconhecido quando estabelece o primeiro conflito da sua vida: separar-se da mãe, sem dela distanciar-se. Estabece-se uma relação de autoconfiança em que ambos são reconhecidos como autodependentes: ele das ações dela e ela do amor dele. Segundo Honneth, esse reconhecimento é privado e não público (HONNETH, 2003). 
O segundo tipo de reconhecimento é o jurídico, em que as leis são a base para a identificação do sujeito. Por meio das leis, as regras e limites da sociedade definem o que o sujeito pode ou não fazer. Tendo leis claramente definidas, o sujeito pode ou não segui-las. As atitudes do sujeito com relação às leis podem defini-lo no sistema social e as relações estabelecidas por meio das leis geram as relações de autorrespeito. Os direitos e os deveres são comuns a todos os sujeitos que, seguindo as regras sociais, demonstram respeito às leis e aos semelhantes (HONNETH, 2003).

No terceiro modelo apontado por Honneth, o reconhecimento é entre o sujeito e a sociedade que o integrava. $\mathrm{O}$ autor expõe:

para poderem chegar a uma auto-relação infrangível, os sujeitos humanos precisam, além da experiência da dedicação afetiva e do reconhecimento jurídico, de uma estima social que lhes permita referir-se positivamente a suas propriedades e capacidades concretas. (HONNETH, 2003, p. 198).

Para o autor, o terceiro modelo de reconhecimento ocorre em uma sociedade de valores, em que o acolhimento sentido pelo sujeito lhe permite expor suas qualidades e seus defeitos, sendo merecedor da solidariedade dos demais integrantes do grupo em que convive (HONNETH, 2003). Esse terceiro tipo de reconhecimento da teoria de Honneth foi complementada pela crítica e discussão de Nancy Fraser, que propõe que o reconhecimento não é questão de mérito, mas de justiça (FRASER, 2006).

Na análise de Fraser (2006), Honneth não observou o sujeito que poderia integrar vários grupos da sociedade e que seria reconhecido em sua multiplicidade. A autora propôs a dualidade para tornar mais fácil a compreensão sobre as possibilidades do sujeito a participar da sociedade.

Fraser também explicitou que o reconhecimento acontece depois de injúrias sofridas, mas difere de Honneth quando propõe que um mesmo sujeito pode sofrer injúrias advindas do vários grupos a que possa pertencer (FRASER, 2006).

Aprofundando as questões e os conflitos que levaram os sujeitos à luta por reconhecimento, Fraser diz que há mudança nas conquistas dos movimentos sociais. No período anterior à queda do Muro de Berlim, a queda do "socialismo real", e a crescente globalização, o reconhecimento das diferenças estava atrelado às recompensas financeiras. A autora, porém, pontua que a recompensa monetária não substitui o reconhecimento (FRASER, 2006). Nos próximos itens dessa pesquisa, buscar-se-á aplicar as propostas dos modelos de reconhecimento de Fraser e Honneth. 


\subsection{O reconhecimento do novo ente pela família}

No primeiro dos modelos, Honneth diz que a família é a que primeiro reconhece o ser humano. $\mathrm{O}$ autor sugere que a família é a primeira a aceitar o ente, seja ele adulto ou criança - adultos, por ocasião de casamentos, e crianças, em virtude do nascimento. A base de pesquisa de Honneth foram famílias europeias (HONNETH, 2003). O tratamento desse tipo de reconhecimento, nessa pesquisa, partirá da contextualização da família negra, quando ainda vivia na África.

Os estudos realizados por Lopes (2006) e Sodré (1998) apresentam a vida familiar africana como uma convivência coletiva. Em muitos povoados e aldeias da África Subsaariana, um homem desposava mais de uma mulher, convivendo com elas muitas vezes sob o mesmo teto ou, ao menos, existia uma intensa convivência entre os filhos das diferentes relações conjugais. Havia também o costume dos avós, pais, filhos, sobrinhos e escravos conviverem no mesmo espaço antes no século XVI, na África, as tribos vencidas tornavam-se escravas (LOPES, 2006).

O ente morto também tinha lugar na família africana, que não o esquecia. Dele vinha o legado e a propriedade que a família possuía, por isso, era obrigação dos familiares louvar e agradar o morto. Esse costume acompanhou o povo escravizado e traficado da África até o Brasil (SODRÉ, 1998).

A partir disso, percebe-se que o núcleo familiar africano era formado por mais pessoas que a família europeia nuclear no século XX, quando Honneth faz o estudo sobre o reconhecimento. A família extensa, com vários entes convivendo sob o mesmo teto, foi observada por Slenes (2011), ao estudar as famílias negras em Campinas, no interior do Estado de São Paulo.

Quando o africano escravizado desembarcou e foi posto à venda, no período colonial brasileiro os laços familiares e afetivos não eram considerados. A compra era feita de acordo com a necessidade do dono da fazenda. A família africana era desfeita, os laços afetivos eram desfeitos, sendo cada membro levado para um local distante (ALBUQUERQUE, 2006).

Essa separação não permitia que os africanos recém-chegados mantivessem a unidade familiar e a identidade de suas tribos ou de suas nações. Segundo Fernandes (2008), o negro era considerado uma mercadoria e, por isso, poderia ser vendido: considerado uma "coisa", não criaria laços afetivos nem desenvolveria unidade familiar. Muitos estudos propunham que as senzalas eram lugares de promiscuidade, uma vez que, para os donos das fazendas, os 
escravizados não estabeleciam novos laços familiares, desfrutando de relações sexuais livres e eventuais (SLENES, 2011). Muitos acreditavam que os africanos escravizados eram desprovidos de alma, praticamente animais e, como animais, o instinto prevaleceria.

Os africanos escravizados criaram novas famílias em uniões, muitas vezes com pessoas vindas de regiões diferentes do continente africano, buscando preencher o lugar da família original, separada no momento da venda. No Brasil, os africanos escravizados criaram laços afetivos e, consequentemente, sanguíneos e sobreviveram ao cativeiro nos diversos ciclos produtivos baseados em trabalho escravo. Nas senzalas, novas famílias eram formadas pelas uniões estáveis de casais, gerando filhos que, quando não eram vendidos, conviviam com os pais (SLENES, 2011). Ainda assim, no período escravista, todos faziam parte do espólio do dono da fazenda, eram considerados mercadoria, como cita Fernandes (2008).

Os fazendeiros tinham que registrar as mercadorias compradas. O meio mais fácil, rápido e mais utilizado era o batismo do escravizado pelos proprietários da fazenda, como cita Netto (2011). No início da colonização e durante todo o período escravista, o batismo era usado como forma de reconhecimento de propriedade e todas as igrejas possuíam livros em que os batismos, casamentos e mortes eram registrados. No Brasil, país em construção, extenso e católico, o registro na igreja possuía uma função que se assemelha àquela de um documento registrado em cartório. Mesmo que, a princípio, a justificativa fosse a de redenção dos negros escravizados, na prática tornava-se uma forma de certificação do objeto possuído.

O batismo, sacramento da religião católica, permaneceu nas famílias criadas pelos africanos escravizados. Em alguns casos, era usado em busca de benefícios e em outros, por simpatia entre os envolvidos. No caso do benefício, o pai pretendia que, por meio do filho, ele e a família conseguissem algum tipo de vantagem social ou financeira. Nem sempre essa opção surtia o efeito tencionado pelos pais (NETTO, 2011).

O compadrio, relações entre os pais da criança batizada e os padrinhos, aumentava a rede de relacionamentos sociais das famílias negras. A rede intersubjetiva criada da relação de compadrio, se formava em torno do batismo da criança, em casos especiais e ao ato do batismo no geral (NETTO, 2011). O compadrio permitiu que as restritas relações dos libertos fossem ampliadas ao longo do tempo, com o aumento do número de pessoas que participavam dos núcleos familiares, no interior paulista ou na capital (SLENES, 2011).

No compadrio, os novos membros fossem crianças, jovens ou adultos eram reconhecidos como parte da família extensa, sendo ela uma referência de pertencimento a um 
determinado grupo escravo, uma referência à família cativa ou à família liberta, constituída ou não por laços sanguíneos (BRÜGGER, 2004).

Durante o último ciclo de monocultura (cafeeiro) as relações de compadrio tiveram mais importância para a população negra (FERNANDES, 2008). Segundo Sodré (1998), para não perecer diante do quadro de abandono à própria sorte, os libertos apoiaram-se em valores sociais vindos da África e mantidos durante o período escravista, em que a família era a base do ser e era composta por muitos membros.

Consoante Ribeiro (2010), no ambiente hostil do período pós-abolição, a população negra, no geral, e o indivíduo, no particular, apoiaram-se nas redes sociais estabelecidas por meio do compadrio. Outra forma de associação, citada no Capítulo 1, foram irmandades religiosas, que também tiveram papel importante na transição da escravidão para o pósescravidão.

Além da falta de políticas públicas no período pós-abolição, outro fator fez do final do século XIX uma época difícil para a população negra: a vinda de imigrantes para trabalhar nas lavouras de café. Esse fato dificultou ainda mais o acesso aos postos de trabalho, à educação e à moradia (MENDES, 2009).

O afrodescendente passou, da condição de escravizado, de mercadoria, de elemento marginal na sociedade escravista, para a condição de desempregado, quando liberto, mantendo a posição marginal na republicana sociedade paulista e na brasileira (FERNANDES, 2008; JESUS, 2004).

Netto (2011) propõe que a liberdade conquistada com a abolição da escravidão, e a possibilidade de sair sem as restrições anteriores fez com que a população negra buscasse na rua atividades em que pudesse obter alguma remuneração. A população negra ampliou as redes sociais quando esperava pequenos serviços ou quando transitava pelos mesmos locais com outros libertos. Essa circulação permitiu o aumento dos vínculos e a manutenção dos indivíduos e das famílias na capital paulista.

Jesus (2004) e Simson (2007) sugerem que as redes estabelecidas, além de ajudarem na busca por postos de trabalho, incentivavam a aproximação entre os libertos, incitavam a formação de grupos familiares cujos laços sanguíneos não eram o ponto central e, seguindo os costumes trazidos da África, estimulavam as reuniões para festejar datas importantes ao som do tambu e depois do bumbo, nos fundos dos quintais. 
Quanto mais pessoas reuniam-se nessas festas, mais pessoas se conheciam e se reconheciam como entes das famílias formadas por vários membros, do ancião até o mais jovem. Esses encontros - comuns nas famílias de origem africana, que tinham por costume louvar os deuses, festejar a vida e chorar a morte com danças e comidas - eram preparados para receber muita gente e para durar bastante tempo (SIMSON, 2007; JESUS, 2004).

O primeiro reconhecimento do indivíduo, citado por Honneth, que se dá pelo afeto, pode ser identificado na situação descrita anteriormente: a criança é reconhecida pelos entes próximos. Esse reconhecimento também pode manifestar-se na relação entre padrinhos e afilhados, na relação entre os compadres e por meio de familiares e amigos (SLENES, 2011).

Esses núcleos familiares, que não eram formados somente por pais e por filhos, foram a origem dos primeiros cordões carnavalescos de São Paulo (SIMSON, 2007). Os primeiros grupos de afrodescendentes dedicados à folia de momo foram formados por familiares, compadres e amigos de seus fundadores (SIMSON, 2007), de maneira semelhante aos afoxés - que saiam às ruas ao som do toque dos orixás, buscando festejar a família de santo, grupo formados por pessoas de famílias diferentes, mas ligadas fortemente pela devoção religiosa (LODY, 1976).

De maneira similar à identificação entre as famílias de santo, que se vislumbravam durante a apresentação do afoxé, as famílias do samba reconheciam-se durante o cortejo do cordão carnavalesco. Nos dois casos, a batida rítmica determinava a identidade dos grupos que se apresentavam e nos dois casos, um símbolo era usado para facilitar a identificação: no afoxé era um boneco ritualístico. No caso do cordão carnavalesco (e depois, da escola de samba) a bandeira, que é conhecida como pavilhão (LODY, 1976), (SIMSON, 2007).

$\mathrm{O}$ vínculo entre os integrantes dos primeiros cordões carnavalescos se assemelhava àquele existente entre os entes familiares. Os integrantes dos primeiros cordões eram originários de famílias extensas, além disso, os integrantes se reconheciam nos cordões carnavalescos e, posteriormente, nas escolas de samba que se tornaram espaços de encontros profissionais e afetivos, de troca de conhecimentos, de socialização, como cita João Roberto Dias, entrevistado durante essa pesquisa: “a minha esposa é originária da Bela Vista [...] ela cresceu na Bela Vista e agora acabou abraçando o Rosas de Ouro.” (02.06.2012) 


\subsection{O reconhecimento da escola de samba no espaço jurídico}

O primeiro, talvez o único, registro dos africanos foi o batismo, como indicado anteriormente. $\mathrm{O}$ registro relacionou-se com a aceitação dos fundamentos e sacramentos católicos (SILVA, 2005) e, principalmente, serviu como atestação de propriedade ao fazendeiro que o comprou (FERNANDES, 2008).

Diferentemente dos imigrantes que chegaram ao Brasil a partir do final do século XIX, que ao desembarcarem no porto, principalmente o de Santos, tinham os dados sobre o país, a cidade, o número de familiares e o destino, registrados em livros da imigração brasileira, como pode ser verificado no registro de matrícula do acervo digital do Museu do Imigrante do Estado de São Paulo9. Os africanos escravizados não eram registrados no desembarque por serem considerados e tratados como carga e não seres humanos (FERNANDES, 2008).

Os demais possíveis registros (registro profissional, registro de casamento etc.) não lhes eram fornecidos, porque durante o período escravista, os escravizados eram considerados parte do espólio. O dono necessitava saber quantos e quem eles eram, mas aos africanos e descendentes era negado o direito de ter representação legal devido à condição de escravizado (FERNANDES, 2008).

O registro do batismo no livro da paróquia servia também como registro de nascimento, sendo que os mais velhos isso não podia ocorrer. O trabalho escravo, em virtude de sua natureza, não gerava registro de trabalho ou qualquer contrato. $\mathrm{O}$ afrodescendente escravizado também não tinha registro de casamento, porque o procedimento era caro e os escravos não tinham recursos. Esta situação perdurou no período escravista, época em que o afrodescendente era considerado um ser marginal na sociedade brasileira (FERNANDES, 2008).

A marginalização em que a população negra manteve-se, mesmo com a abolição da escravidão, pois os afrodescendentes continuaram sem acesso às políticas públicas que lhes colocassem em situação de igualdade com os imigrantes. Nesta condição, tudo o que partia dos libertos era recebido pela sociedade como marginal, vindo de uma população marginal, tida desde o período escravista como inferior (FERNANDES, 2008).

As culturas negras trazidas da África e mantidas, total ou parcialmente, desde o tempo da senzala, eram consideradas exóticas pelos donos das fazendas. As festas organizadas pelos

\footnotetext{
${ }^{9}$ Disponível em: <www.museudaimigracao.org.br/acervodigital/sobre.php>. Acesso em: 2 nov. 2013.
} 
escravizados eram permitidas para evitar revoltas e não em respeito às crenças, aos valores ou aos costumes das populações negras (FERNANDES, 2008; JESUS, 2004). A crença das populações negras em divindades ligadas à natureza eram vistas, pelos senhores de escravos, como adorações ao diabo. Eles desconheciam o fato de que nas culturas africanas não existe essa figura, originária da fé cristã (SILVA, 1994). Essa condição não foi alterada com o fim do período escravocrata, uma vez que muitos sacerdotes das religiões de matriz africana foram presos no exercício de sua fé.

Outro exemplo do desrespeito à cultura negra aconteceu com a capoeira: a arte marcial de origem negra foi proibida pelo código penal de 1890, pois era vista como geradora de brigas e confusões ${ }^{10}$. Mais tarde, no final do século XX, a capoeira foi declarada patrimônio histórico do país.

A primeira forma de manifestação carnavalesca encenada pela população negra foi vaiada e ridicularizada durante as apresentações nas festas católicas, que deixou de existir na capital paulista (JESUS, 2004). A apresentação dos primeiros cordões carnavalescos na capital paulista aconteceram sob os olhos ciosos dos órgãos policiais e do olhar preconceituoso da sociedade paulistana (SIMSON, 2007).

Depois do primeiro desfile, que surpreendeu os moradores da região da Barra Funda, não sofrendo repressão explícita, nos anos seguintes, o cordão da Barra Funda (ou Camisa Verde, como ficou conhecido) parava o cortejo em frente à delegacia central da cidade e apresentava-se para conquistar a simpatia da autoridade policial, buscando minimizar ou evitar possíveis agressões por parte de policiais. Entre os anos de 1930 e 1960, os representantes das escolas tiveram que ir às delegacias de polícia pedir autorização para que o desfile acontecesse (SIMSON, 2007; JESUS, 2004). Em outras ocasiões, foi necessário registrar o cordão carnavalesco na delegacia de ordem pública e no dia do desfile carimbar o pavilhão, para que o folguedo pudesse desfilar nas ruas (SIMSON, 2007).

Além do desrespeito aos costumes e às culturas negras, apresentado pelos órgãos públicos, a captação de recursos financeiros era outro problema enfrentado pelos primeiros cordões carnavalescos. A ajuda financeira era fornecida pelos próprios componentes das agremiações, cuja maioria ganhava pouco, o suficiente para a subsistência, não podendo colaborar com quantias elevadas. A criação do "Livro de Ouro" objetivava a resolução da

10 Disponível em: <http://pt.scribd.com/doc/55636995/Codigo-Penal-de-1890-Completo>. Acesso em: 2 nov, 2013. 
questão financeira. Os primeiros cordões carnavalescos levavam o Livro aos comerciantes da região onde o cordão ensaiava e anotavam os dados do doador. Cada escola tinha seu próprio livro e recolhia as arrecadações no bairro de origem (SIMSON, 2007).

O dinheiro obtido por meio das doações tornou-se insuficiente para a confecção das fantasias e das alegorias dos componentes, que aumentavam ao longo do tempo. Então, os responsáveis pelos desfiles criaram uma entidade que agregasse os cordões carnavalescos e buscaram a ajuda do poder público (JESUS, 2004).

A negociação com o poder público, porém, não foi realizada pelos representantes dos cordões ou das escolas de samba, mas sim, por um jornalista. Por que isso teria acontecido?

Segundo Fernando Penteado, um dos entrevistados dessa pesquisa (em 30/05/2012), Moraes Sarmento, natural do interior de São Paulo e filho de italianos, foi escolhido por ser um defensor da cultura popular brasileira, ser contra a invasão de ritmos e elementos internacionais à música brasileira ${ }^{11} \mathrm{e}$ também, por ser jornalista e radialista.

No final dos anos 1960, os representantes das escolas de samba sabiam a importância da existência de um porta-voz junto ao poder público e à imprensa, acostumada a noticiar apenas os vencedores dos desfiles de Carnaval e os problemas enfrentados pelas escolas (SIMSON, 2007).

Além disso, ainda pode-se sugerir que restava na memória um expediente usado durante o período escravista: a escolha de um homem branco para apadrinhar o filho. $\mathrm{O}$ apadrinhamento gerava benefícios ao afilhado e, em extensão, à família do apadrinhado (GRÜBBER, 2004). Pode-se sugerir que o filho a ser batizado, nesse caso, era a entidade que reunia as escolas e os cordões e a escolha de Moraes Sarmento como padrinho buscava a legitimação da entidade.

O papel de presidente (ou do padrinho) desempenhado por Moraes Sarmento foi importante para as intenções do grupo, que, além de aproximar-se do poder público, conquistou espaço junto à imprensa (SIMSON, 2007).

No início do século $\mathrm{XX}$, primeiros anos dos cordões carnavalescos, a imprensa noticiava com ênfase e destaque apenas o carnaval branco: o desfile do corso na avenida Paulista. Os carnavais que ocorriam em outras localidades da cidade - como o desfile do Brás que atraía muita gente - recebiam pouca ou nenhuma atenção. O carnaval negro dos cordões

\footnotetext{
${ }^{11}$ Disponível em: <www.netsaber.com.br/biografias/ver_biografia_c_4566.html>. Acesso em: 2 nov. 2013.
} 
carnavalescos era noticiado não como folguedo, mas como baderna, quando havia brigas ou confusões (SIMSON, 2007).

Os dados apresentados por Simson sugerem que depois de 30 anos da abolição, as páginas de jornal da sociedade paulista ainda apresentavam os afrodescendentes como grupos de arruaceiros, noticiando os eventos negativos do carnaval negro. Apesar de identificados com a imagem negativa que a sociedade paulistana construiu a seu respeito, os cordões carnavalescos seguiram ocupando as ruas e fazendo a alegria de afrodescendentes e pessoas de outras etnias que apreciavam as evoluções dos grupos (SIMSON, 2007).

Tendo em vista a redução do carnaval branco, a imprensa voltou-se ao crescimento do desfile dos cordões carnavalescos. A TV Paulista televisionou um desfile de cordões carnavalescos no bairro da Lapa, aproveitando a infraestrutura que havia sido montada pela associação comercial da região. Com o passar dos anos, segundo Simson (2007), os jornais, as emissoras de rádio e de televisão passaram a noticiar o carnaval negro, uma vez que o corso e os bailes de carnaval foram abandonados por falta de local de realização.

Em meados do século XX, com o apoio de associações comerciais de bairros que outrora organizavam os desfiles dos blocos carnavalescos brancos (geralmente originários de grupos imigrantes), o carnaval de rua, com desfiles de cordões carnavalescos e ranchos, ganhou força na capital (SIMSON, 2007). Os eventos organizados pelas associações comerciais levavam bastante público às ruas para ver os desfiles. Mesmo assim, o carnaval negro ainda refletia o que era vivenciado pelos afrodescendentes: preconceito, desprezo e desconfiança (SIMSON, 2007).

No final da década de 1960, os dirigentes dos cordões e das escolas de samba decidiram criar uma associação que os representasse,para reverter a situação desconfortável descrita anteriormente. Os afrodescendentes, que eram maioria no comando dos cordões carnavalescos e escolas de samba, ainda tinham pouca representatividade junto à mídia (FERRARA, 1986). Quanto ao poder público, ainda na década de 1960, quando os concursos e os desfiles eram organizados por associações comerciais e emissoras de rádio ou jornais, os afrodescendentes quase não tinham acesso (SIMSON, 2007; JESUS, 2004),

A escolha de Moraes Sarmento permitiu que a agremiação se estabelecesse como entidade representativa de cordões carnavalescos e escolas de samba, conseguindo inserir os desfiles no calendário da capital paulista e recebendo verbas do poder público (SIMSON, 2007). 
Apesar de os cordões e escolas de samba terem 20 anos ou mais de fundação e de apresentações sem interrupções, foi a partir da fundação da entidade Federação das Escolas de Samba, segundo Fernando Penteado, que o carnaval paulistano de ascendência negra passou a ser reconhecido: "enquanto é ilícito é coisa de negro [...] passou a ser lícito, o branco pega para ele", completou o autor.

O surgimento, o desenvolvimento e a apresentação pública dos cordões carnavalescos e das escolas de samba na sociedade capitalista em que a crescente necessidade de dinheiro para a confecção de fantasias, para a compra e reforma de instrumentos e para construção das alegorias é uma constante fez com que os representantes se organizassem em uma única entidade representativa junto ao poder público. O poder público, que aceitou subvencionar os desfiles paulistanos, não conhecia o carnaval negro da capital, assim, estabeleceu o regulamento do concurso paulistano com base nas regras determinadas no carnaval carioca (SIMSON, 2007). Com base nesse regulamento, que unificou o desfile carnavalesco, as entidades passaram a remodelar-se plasticamente. Além disso, todas as entidades que auxiliaram a fundação da primeira, bem como aquelas que surgiram depois, passaram a ter uma identificação jurídica junto à sociedade paulistana (SIMSON, 2007).

Segundo a Liga Independente das Escolas de Samba de São Paulo (Liga) e a União das Escolas de Samba Paulistanas (Uesp) todas as escolas de samba que participaram dos desfiles carnavalescos na cidade de São Paulo, entre os anos de 2010 e 2013, possuíam Cadastro Nacional de Pessoa Jurídica (CNPJ) e registro em cartório ${ }^{12}$.

\subsection{O reconhecimento do ser como parte do todo}

O terceiro tipo de reconhecimento discutido por Honneth (2003), em que o autor analisa e aprofunda os estudos produzidos por Hegel e Mead, é a autorrealização e a autoestima. Para o autor, trata-se de um reconhecimento que o sujeito faz dele mesmo, dentro da sociedade em que vive. Segundo Honneth, parece ser o tipo mais difícil de reconhecimento: aquele em que o ser humano reconhece-se como parte de algo maior, a sociedade (HONNETH, 2003). Esse reconhecimento é buscado pelo indivíduo depois que ele passa por algum episódio desrespeitoso, imposto a ele ou a outro sujeito, mas que o ofenda. $\mathrm{O}$

12 Disponível em: <www.ligasp.com.br> e <www.spturis.com/carnaval/2012/escolas.php>. Acesso em: 2 nov. 2013. 
terceiro tipo de reconhecimento proposto por Honneth está presente na matéria dessa pesquisa.

Nancy Fraser (2006) expande o campo de estudo do reconhecimento do indivíduo frente à sociedade proposto por Honneth e apresenta um novo parâmetro de observação. Diferentemente de Honneth, a autora propõe que o reconhecimento não é uma questão de autorrealização do sujeito ou de mérito pessoal, mas o sujeito é integrante de partes sociais. A autora expõe que a sociedade não é formada por um bloco único, mas por vários grupos menores que coexistem. O sujeito pode integrar mais de um grupo social ao mesmo tempo. Diferentemente da proposta de Honneth, Fraser questiona se o reconhecimento seria um mérito para o indivíduo ou uma questão de justiça frente às diferenças sociais e econômicas da sociedade capitalista, principalmente após o final do século XX (FRASER, 2006).

As propostas do estudo de Fraser permitiram analisar a postura dos atuais integrantes das escolas de samba paulistas e dos participantes que fizeram parte de manifestações carnavalescas anteriores. Fraser indica que o reconhecimento é buscado por quem não tem poder econômico ou social, pois os poderosos são reconhecidos e valorizados (FRASER, 2006). Na sociedade brasileira, o grupo menos valorizado é o formado por afrodescendentes condição que pouco ou nada se alterou desde o fim do período escravista (FERNANDES, 2008).

Segundo Fernandes (2008) e Guerreiro Ramos (1957), as entidades carnavalescas paulistas de origem afrodescendente foram fundadas e desenvolveram-se dentro de um parâmetro social que possuía as seguintes características: composta de afrodescendentes recém-libertados das senzalas que viviam à margem da sociedade; as manifestações dos negros eram consideradas como menores e atrasadas; as relações familiares, quando existiam, eram frágeis e muitos acreditavam que eles não poderiam dirigir ou manter entidades organizadas pois eram intelectualmente incapazes. Foi em meio a este cenário preconceituoso que os cordões carnavalescos e depois as escolas de samba desenvolveram-se, cresceram e agregaram componentes.

O aumento no número de participantes foi lento nos primeiros anos. Em 1914, havia um pouco mais de 10 pessoas que participaram da primeira apresentação do cordão Barra Funda, conhecido como Camisa Verde. A partir de 1967, após a regulamentação e a regularização, o aumento foi acelerado. Em 1980, as agremiações apresentavam-se com cerca 
de 300 pessoas, no Carnaval de 2013, a Vai-Vai desfilou com aproximadamente 4 mil integrantes.

Após a discussão do quadro em que se desenvolveram os cordões, pode-se questionar: por que, mesmo diante de todas as adversidades, as agremiações carnavalescas não foram esvaziadas? Por que as pessoas continuam integrando-se a elas? Uma possível resposta para esta questão pode estar relacionada à presença de elementos da cultura afrodescendente nas escolas de samba: os primeiros cordões carnavalescos surgiram no seio de família de origem africana. Além disso, o samba, ritmo que embalou os ensaios, os desfiles e a dança executada pelos foliões, derivado do batuque, tinha origem africana (JESUS, 2004).

A origem africana não se restringiu ao som do batuque, aos componentes lúdicos do desfile e à diversão carnavalesca. Segundo Muniz Sodré, o africano reverenciava seus ancestrais cantando e dançando. Parte dos costumes trazidos pelos primeiros africanos escravizados que chegaram no século XVI no país se perpetuaram e permanecem vigentes no século XIX (SODRÉ, 1998).

O envolvimento e o engajamento dos afrodescendentes com seus costumes culturais permaneceram, como o legado da reverência e do culto deixado pelo ancestral. Manter e cuidar do cordão carnavalesco e, posteriormente, da escola de samba, seria como reverenciar e cultuar o legado deixado pelo ancestral, mesmo que ele estivesse morto. A família de origem negra mantinha viva a memória em relação àquele que faleceu. Essa família extensa, formada por integrantes consanguíneos ou não, assemelhava-se a uma tribo ou a uma nação (LOPES, 2006).

Em entrevista concedida para este trabalho, Fernando Penteado indicou que o pavilhão de uma escola de samba identifica uma nação. Mas o que seria essa identificação? Qual seria essa nação? Honneth (2003) sugere, como apresentado anteriormente, que o desrespeito sofrido por uma pessoa faz com que ela lute por reconhecimento, levando essa pessoa a se identificar como parte da sociedade. Pode-se propor que o desrespeito sofrido pelos africanos e por seus descendentes em todo o mundo, e em especial no Brasil, foi a escravidão. Nesta fase da História, os africanos eram colocados na condição de animalidade.

A nação, referida pelo entrevistado, seria formada por afrodescendentes que sofreram, até o início do século XXI, momento desta pesquisa, os efeitos da escravidão vivenciados por seus ancestrais. Os afrodescendentes foram vítimas de julgamentos, como aqueles realizados por Nina Rodrigues e Oliveira Viana, sobre a incapacidade intelectual da população negra. As 
conclusões dos estudos de Nina Rodrigues e Oliveira Viana serviram de base científica para a política do branqueamento do povo brasileiro empenhada pelos governantes e impostas à sociedade brasileira (RAMOS, 1957).

Transcorrido mais de um século entre o final da escravidão e o início do século XXI, não se extinguiram as diferenças de tratamento, de oportunidades e de condição social existente entre afrodescendentes e os demais. Para reduzir tais distâncias, no início do século XXI, o governo federal do Brasil criou e colocou em funcionamento leis que deveriam estar presentes no século XIX, junto com o fim da escravidão (FERNANDES, 2008).

Essas ações não estiveram presentes durante grande parte do século XX, fazendo com que e as populações negras sobrevivessem e se mantivessem como foi possível: vivendo de subempregos (ou de empregos eventuais e temporários), morando nos piores locais, frequentando por poucos anos os bancos escolares e morrendo cedo. Durante o século XX, o afrodescendente permaneceu marginalizado na sociedade brasileira e, especialmente, na paulistana (FERNANDES, 2008). Nesta pesquisa não será aprofundada a discussão sobre a implantação das ações afirmativas pelo governo federal.

O pequeno espaço de congraçamento e de liberdade dos afrodescendentes na sociedade capitalista paulistana do século XX foi o cordão carnavalesco e depois a escola de samba. Liberdade e congraçamento porque, na agremiação carnavalesca de origem negra, o afrodescendente podia dançar suas danças, cantar seus sambas e conviver com seus iguais (SIMSON, 2007), além disso, ele podia aumentar sua rede de relacionamentos sociais, buscar ajuda material, financeira e amparo emocional.

As agremiações carnavalescas também eram locais de conscientização do afrodescendente, participante na sociedade paulistana do século XX. A escravidão fora extinta, mas a "condição de escravidão", o desrespeito e o "cativeiro" perduravam (SIMSON, 2007).

A busca da realização do desfile das agremiações carnavalescas fez com que os componentes argumentassem com comerciantes na rua, em busca de recursos financeiros, e com o poder público, em busca de autorização do desfile carnavalesco nas ruas. A interação entre o grupo elitizado branco e o grupo subalternizado negro fez com que os afrodescendentes criassem mecanismos de defesa, desenvolvessem seus argumentos e demonstrassem a capacidade intelectual colocada em questão pela política do branqueamento (FERNANDES, 2008). 
Durante muito tempo, depois dos primeiros desfiles carnavalescos, as agremiações tiveram que pedir autorização policial para sair às ruas. A escravidão fora extinta, mas a condição escrava permanecia: o afrodescendente ainda precisava pedir para a autoridade policial, equivalente à figura do dono da fazenda no período escravista, o direito de utilizar as ruas. No caso das agremiações carnavalescas, o carimbo da autoridade policial no pavilhão era a atestação de que a agremiação poderia desfilar na rua (JESUS, 2004).

Apesar da legalização dos desfiles carnavalescos, cientes da condição desfavorável do povo afrodescendente, os representantes das escolas de samba escolheram Moraes Sarmento um branco para representá-los (SIMSON, 2007). Agindo assim, obtiveram a aceitação do poder público, valendo-se do apadrinhamento (SLENES, 2011).

Os integrantes e representantes das agremiações carnavalescas formavam um grupo heterogêneo na sociedade paulista, mas compartilhavam a experiência do preconceito sofrido por afirmarem-se componentes dos cordões carnavalescos, inicialmente, e depois das escolas de samba. Onde há preconceito, existe a necessidade de reconhecimento (FRASER, 2006).

Fraser (2006), que aprofundou e expandiu as ideias de Honneth, expôs que o reconhecimento não é um mérito conquistado, mas a necessidade de justiça social. Os integrantes das agremiações carnavalescas foram e continuam sendo vítimas de injustiças sociais, assim como a população negra.

Uma derivação dessas injustiças e do preconceito presente na sociedade paulistana, é que a assunção oficial da produção cultural das classes subalternas ocorreu apenas no último quartel do século $\mathrm{XX}$, a partir de um representante branco que deu visibilidade à nação dos sambistas, vista como produtora cultural (SIMSON, 2007).

Porém, o reconhecimento foi parcial porque, para criar o concurso entre as agremiações paulistanas, utilizou-se o regulamento carioca que não contemplava os cordões carnavalescos. Com as novas regras, os principais cordões carnavalescos paulistanos não ganharam os primeiros concursos disputados e, para não serem extintos, alteraram suas características conforme o regulamento. A nova regra criada levou à extinção dos cordões que eram a principal manifestação carnavalesca paulistana (SIMSON, 2007).

O regulamento trouxe mudanças na forma de apresentação das agremiações em virtude da nova maneira que eram avaliada durante os desfiles. Os instrumentos de sopro, a figura do rei e da rainha das escolas, com suas fantasias muito semelhantes aos dos reis das congadas e do maracatu, foram suprimidos (MORAES, 1989). A mudança na estrutura do 
folguedo, porém, não fez com que os seguidores se afastassem. Os componentes das escolas de samba interessaram-se mais pelo conteúdo que pela forma.

Durante as pesquisas de campo dessa dissertação verificou-se que o título não é a principal preocupação do componente da escola de samba; se ele vier, melhor. O componente se interessa em construir um belo espetáculo, em entreter e extasiar o público. A luta do componente da escola era para que o espetáculo elaborado por ele, depois de ter sido pensado pelo carnavalesco, fosse motivo de admiração das pessoas que iriam ao sambódromo do Anhembi. Era um trabalho feito em grupo, para o grupo (BLASS, 2007).

As pessoas que compõem o grupo engajado nas agremiações carnavalescas participam das atividades desenvolvidas pela escola de samba durante o ano e não fazem parte do grupo que compra a fantasia pouco tempo antes do Carnaval, aprende a cantar o samba ouvindo o $\mathrm{CD}$ e comparece a apenas alguns ensaios. Os componentes do grupo engajado são indivíduos, cuja identidade foi cunhada junto à escola de samba, comprometidos e engajados e fazem com que a agremiação não seja apenas divertimento, como fez o folião comum, mas uma obrigação da vida, como trabalhar e estudar. Foi este grupo que, ano após ano, transmitiu as características da escola de samba para os novatos, ao preservar, conforme preconiza a cultura negra, o legado deixado pelos ancestrais (LOPES, 2006). Essas pessoas lutaram, cotidianamente, pelo fim do preconceito contra os integrantes de escolas de samba e pelo reconhecimento do grupo como produtor de grandes eventos, como responsável por manter viva parte da cultura popular paulistana.

\subsection{Quando a cultura dominante absorve a cultura subalterna: a entrada de contingentes de brancos nas escolas de samba paulistanas}

Durante apresentação no programa "Invenção do Contemporâneo", Muniz Sodré disse que reconhecer a diversidade do outro ${ }^{13}$ é a mais importante manifestação de respeito. Sodré propôs também que a cultura negra considerada por alguns como primitiva e atrasada em relação à cultura eurocêntrica - é diversa e formada pela união de várias culturas de diferentes povos africanos. A expressão da cultura de origem africana dá-se a partir do falar, do cantar,

\footnotetext{
13 Disponível em: <www.cpflcultura.com.br/2011/04/05/a-ignorancia-da-diversidade-\%E2\%80\%93-muniz-
} sodre/>. Acesso em: 2 nov. 2013. 
do dançar e do agir, enquanto a hegemônica europeia é centrada na racionalização. A primeira viveu e vivenciou o saber, a segunda abstraiu o conhecimento ${ }^{14}$.

Segundo Oliveira (2009), a cultura hegemônica eurocêntrica que se manifesta unificada, foi desenvolvida em vários países. Ela foi produzida no nível intelectual e o consumidor dela não a vivenciava. Advinda do Iluminismo, cujo pensamento lógico foi conduzido aos extremos, a cultura europeia que domina o mundo atualmente, mesmo com a ascensão dos Estados Unidos, foi produzida pela cabeça e não pelo corpo. Durante a Idade Média europeia, os conhecimentos eram adquiridos por meio do esforço e da ação do corpo, modelo distante daquele vivenciado nos dias atuais.

A cultura subalterna, por outro lado, foi produzida e vivenciada tanto pelo artista quanto pelo admirador. As obras eram produzidas de acordo com as ideias, os raciocínios e os objetivos de cada um dos artistas e sentidas no corpo do artista e do usuário. Nesta cultura ancestral, em que a obra de arte participava do dia a dia e era desfrutada, o objetivo de sua produção não era a exposição (OLIVEIRA, 2009).

Os africanos não perpetuavam suas artes, suas lendas, suas técnicas de cultivo e de criação, enfim, sua cultura, por meio da escrita. O conhecimento era transmitido oralmente para seus descendentes. Desta forma, a informação era vivenciada tanto por quem a propagava como por quem a ouvia, assim o aprendizado era vivido pelo aprendiz (LOPES, 2006).

Quando os europeus depararam-se com os africanos, acharam que eles eram seres primitivos, em virtude da falta da escrita. A oralidade não era reconhecida como uma forma de transmissão de conhecimento. A falta de entendimento e de reconhecimento da diversidade cultural na África fez com que os europeus a classificassem como menor ou inferior. Nas relações de poder (CORRÊA, 2012) que foram estabelecidas com os africanos, os europeus desconsideraram ou reduziram muito a importância dos saberes transmitidos oralmente, porque para eles, a escrita era a única forma de perpetuação e preservação do conhecimento. Assim, para eles, os africanos eram desprovidos de conhecimento, não tinham saberes. Junto com a dominação dos povos africanos por meio das armas e da força, os europeus tentaram dominar intelectualmente os africanos. Para isso, desqualificaram seus saberes. $\mathrm{O}$ africano foi

14 Disponível em: <www.cpflcultura.com.br/2011/04/05/a-ignorancia-da-diversidade-\%E2\%80\%93-munizsodre/>. Acesso em: 2 nov. 2013. 
subjugado pela força física, mas manteve as próprias formas de conhecimento, que chegaram e foram mantidas no Brasil.

A diversidade cultural vivenciada pelos povos africanos foi a referência para a necessidade de se entender, aceitar e reconhecer o outro, na chegada ao Brasil.

Antes de terem sido escravizadas pelos europeus, as populações negras mantinham relações de poder umas com as outras, agregavam saberes, valores e costumes de outras etnias negras e de outros povos. No Brasil, durante o período escravista, esse comportamento de agregação perdurou. Parte da cultura original dos afrodescendentes no século XIX foi preservada e outra parte foi adquirida de outros povos (SODRÉ, 1998). Da invasão da África aos dias atuais, as culturas negras foram expostas à cultura hegemônica mas, mesmo assim, conseguiram manter muitas de suas características. (OLIVEIRA, 2009).

A capacidade de agregar e adaptar saberes é comum às culturas subalternas, em especial à cultura negra que mesmo segregada pela sociedade paulistana, reconheceu a diversidade do outro ${ }^{15}$.

Inicialmente, a maioria dos dirigentes das agremiações carnavalescas eram pessoas de origem africana. Depois que o folguedo foi oficializado, o número de não afrodescendentes aumentou paulatinamente, principalmente em cargos de comando das agremiações (SIMSON, 2007).

Simson relata que nas primeiras décadas do século $\mathrm{XX}$, os brancos acompanhavam os desfiles das calçadas. Muitos ajudavam financeiramente, mas não integravam às atividades dos primeiros cordões. Posteriormente, entre as décadas de 1920 e 1930, com a fundação do cordão carnavalesco Vai-Vai e da escola de samba Lavapés, alguns não afrodescendentes venceram a barreira do preconceito e integraram os quadros das agremiações (SIMSON, 2007).

A dificuldade na entrada de não afrodescendentes nas agremiações não vinha da negação dos afrodescendentes, mas sim, da falta de interesse dos grupos. Vencer a barreira da hegemonia cultural e participar de um folguedo considerado inferior pode ter sido um dos motivos que levaram os não afrodescendentes a integrarem-se nas agremiações carnavalescas depois que um órgão oficial reconheceu o festejo de origem negra (SIMSON, 2007).O poder

15 Disponível em: <www.cpflcultura.com.br/2011/04/05/a-ignorancia-da-diversidade-\%E2\%80\%93-munizsodre/>. Acesso em: 2 nov. 2013. 
público fez com que a integração entre os representantes da cultura hegemônica e os da cultura subalterna fosse reconhecida e valorizada (OLIVEIRA, 2009).

No início do século XX, tanto os afrodescendentes como as mulheres eram ainda mais segregados do que nos dias atuais. As mulheres não afrodescendentes também eram segregadas e fazer parte de um folguedo negro poderia trazer-lhes mais motivos para ampliar a segregação. Desde os primeiros anos de apresentações, as mulheres negras, familiares dos fundadores das agremiações carnavalescas, participavam dos folguedos(SIMSON, 2007). Mesmo sendo vítimas de preconceitos, as mulheres não afrodescendentes, após, aproximadamente, cinco décadas, integraram-se às escolas de samba (FRASER, 2006).

A oficialização dos desfiles carnavalescos fez com que os folguedos de origem negra, na capital paulista apresentassem novas características. No final da década de 1989, limite do estudo de Simson, o número de afrodescendentes nos quadros das escolas e entre os dirigentes havia diminuído (SIMSON, 2007).

Fernando Penteado, entrevistado e filho de um dos fundadores do cordão carnavalesco Vai-Vai, sintetizou com clareza o fenômeno: "enquanto é ilícito é coisa de negro... passou a ser lícito, o branco pega para ele."

O reconhecimento do folguedo negro pelo poder público levou dinheiro às agremiações, o que permitiu a melhoria do visual das escolas, fazendo com que o espetáculo ficasse mais atraente para quem o assistia (SIMSON, 2007).

Outra vantagem trazida com a oficialização e com o apadrinhamento de Moraes Sarmento foi a exposição das escolas de samba nos meios de comunicação da época. Anteriormente, alguns jornais, emissoras de rádio e de televisão se interessavam pelos concursos das associações comerciais dos bairros, mas a oficialização fez com que a cobertura se tornasse obrigatória, fazendo parte do calendário de eventos da cidade. Nos primeiros anos dos desfiles carnavalescos de origem negra na capital, os jornais noticiavam apenas as confusões e as brigas que ocorriam (SIMSON, 2007).

Não foram apenas vantagens que vieram com o reconhecimento da agregação promovida pelas entidades carnavalescas da capital paulista. A primeira desvantagem a utilização do regulamento trazido do Rio de Janeiro, em vez da adoção de um regulamento criado após discussões em São Paulo. Tal atitude fez com que os cordões carnavalescos se extinguissem, uma vez que os elementos que os compunham e que os caracterizavam, como 
os instrumentos de sopro, não eram contemplados pelo novo regulamento (SIMSON, 2007: JESUS, 2004).

Diante das novas regras, os mais importantes cordões carnavalescos de São Paulo que não obtiveram boas colocações na disputa, transformaram-se em escolas de samba (SIMSON, 2007).

O exemplo de adaptação das populações negras às novas regras, respeitando e agregando novos conhecimentos e formas de pensar, pode ser verificada nas mudanças na forma de apresentação dos antigos cordões carnavalescos, que além de não se desestruturarem, ainda tornaram-se escolas de samba. Os dois principais cordões carnavalescos, no momento da oficialização dos desfiles, foram as agremiações vencedoras do carnaval paulistano ${ }^{16}$.

A mudança de cordão carnavalesco para escola de samba deu-se pela exigência das novas regras. Ela foi executada por componentes engajados dos antigos modelos de agremiação, que adaptaram o modelo anterior ao novo modelo imposto. Fernando Penteado e Edson Paulino, entrevistados durante essa pesquisa, vivenciaram a transição descrita. Além de componentes da escola de samba, eles tinham outras identidades sociais: religião, orientação sexual, profissão e estado civil (FRASER, 2006).

As formas de identificação e reconhecimento podem deixar de existir, uma vez que são vivas e construídas dia após dia. A perda de uma dessas formas de identificação foi observada em 2011 na escola de samba Pérola Negra. O carnavalesco André Machado e o diretor de harmonia, Ednaldo Santos comentaram, (não foram entrevistas formais como as que me baseei p/ esta dissertação. Foram conversas mesmo) durante entrevistas da pesquisa de campo desse estudo, realizadas nos preparatórios dos desfiles de 2012, que a ala das baianas vinha de outra cidade, porque as baianas da escola não eram suficientes para cumprir a regra do regulamento,

O desligamento dos componentes foi citado na reportagem, publicada em 2 de fevereiro de 2013, de Luiz Antonio Simas, no jornal $O G l o b o^{17}$. O autor indicou um fato que ocorreu Rio de Janeiro e foi observado durante esta pesquisa: o esvaziamento da ala das

\footnotetext{
${ }^{16}$ Disponível em: <www.ligasp.com.br>. Acesso em: 2 nov. 2013.

17 Disponível em: <http://oglobo.globo.com/opiniao/as-velhas-baianas-somem-da-passarela-7455921>. Acesso em: 2 nov. 2013.
} 
baianas. As escolas de samba tiveram que formar baianas mais novas para obter o número mínimo determinado pelo regulamento. Por que estaria acontecendo este êxodo?

Luiz Simas propõe que o motivo desta saída seria o fato de grande parte das senhoras que compunham tal ala terem deixado o catolicismo, o espiritismo, a umbanda e o candomblé e abraçado a religião pentecostal. A ala das baianas tinha ligação direta com as mães de santo e eram homenageadas nas escolas de samba. Elas mantiveram acesa a chama do samba de origem baiana em terras cariocas desde o final do período escravista. Tendo em vista que as igrejas pentecostais eram avessas às religiões de matriz africana, as escolas de samba tinham perdido muitas baianas (LOPES, 2003; SILVA, 2007).

Em contrapartida, algumas escolas de samba buscaram pessoas em grupos de terceira idade ou em grupos culturais vindos de cidades do interior para desfilar na ala das baianas. Elas aceitavam participar nessa ala que possuía uma presença religiosa tão marcada. Mulheres, e alguns homens que também se vestiam de baiana, foram expostos a uma nova atividade, muitas vezes muito diferente daquelas que estão acostumados e identificavam-se, mas cunharam uma nova identidade.

A perda da identidade daqueles que abandonaram o ambiente das escolas de samba e a constituição de novas identidades, permite-nos observar o quanto é dinâmico o processo de reconhecimento e identificação do indivíduo com o meio ao qual foi exposto.

Além disso, verificou-se que a recompensa monetária, como diz Fraser (2006), nem sempre, representa o reconhecimento buscado pelo componente na escola de samba. $\mathrm{O}$ modelo da autora, elaborado após a queda do Muro de Berlim, explicita uma informação que Honneth não apresenta em seus estudos: a recompensa monetária não seria a única forma de reconhecimento que o indivíduo busca. Por vezes, a recompensa monetária sequer é aceita. No terceiro modelo de reconhecimento, o autorreconhecimento, a recompensa monetária nem sempre é vislumbrada, diferentemente do reconhecimento jurídico, em que uma ofensa pode gerar um processo que leva à correção do erro, ao pagamento monetário e ao reconhecimento do acerto do pleiteante na questão que foi julgada.

Apesar de Fraser e Honneth pertencerem à mesma geração, eles observaram os modelos de reconhecimento por ângulos diversos: ela é uma mulher nascida nos Estados Unidos, enquanto ele é um homem de origem alemã. Os resultados obtidos, diversos e complementares, demonstram que o autorreconhecimento ocorre em todos os círculos aos 
quais o sujeito pertence. Segundo Fraser (2006), a diversidade da vida de cada indivíduo lhe permite ser reconhecido em diversas esferas nas quais ele circula.

Nas escolas de samba, observou-se, durante o trabalho de campo, a diversidade de pessoas, com perfis e meio de vivência diferentes, em que o primeiro e o segundo modelos de reconhecimento eram facilmente observados: todos os componentes tinham família ou faziam parte de algum grupo familiar e todos tinham nome, o primeiro dos reconhecimentos jurídicos, além da identificação que a própria escola de samba lhes tinha dado. $\mathrm{O}$ autorreconhecimento, terceiro tipo de reconhecimendo que leva o sujeito a se identificar como parte da sociedade, também foi verificado: mesmo não sendo consciente, manifestava-se claramente por meio do orgulho de fazer parte desta ou daquela agremiação carnavalesca.

\subsection{O vínculo, o compromisso e o engajamento nas agremiações carnavalescas}

Os conceitos anteriormente apresentados auxiliaram a compreensão sobre os motivos que levam o folião a dedicar-se e entregar-se de forma tão intensa para as escolas de samba, sabendo que a remuneração não era o motivo principal. O que levaria os não afrodescendentes a acompanhar as escolas de samba? Que transformações pessoais levaram os afrodescendentes e outros grupos étnicos às agremiações carnavalescas?

Os estudos de Pichon-Rivière (2000), realizados na área da Psiquiatria, podem esclarecer as questões apresentadas, motivadoras desse estudo: o que leva uma pessoa a dedicar-se a uma escola de samba? Pichon-Rivière (2000) observou que as patologias dos pacientes estavam relacionadas aos vínculos que estabeleciam com os objetos e com os sujeitos com os quais relacionavam-se. Para chegar à motivação do estabelecimento de vínculos, investigou-se a vida do paciente no ambiente em que ele convivia:

Uma psiquiatria concebida a partir das relações interpessoais, da relação do indivíduo com o grupo e/ou com a sociedade, nos dará dados para construir uma psiquiatria que podemos denominar Psiquiatria do Vínculo, quer dizer, a psiquiatria das relações interpessoais. Uma psiquiatria concebida deste modo é uma psiquiatria dinâmica construída com os postulados da psicanálise. [...]Isso nos leva a tomar como material de trabalho e observação permanente a maneira particular pela qual cada indivíduo se relaciona com outro ou outros, criando uma estrutura particular a cada caso e a cada momento, que chamamos de vínculo (PICHON-RIVIÈRE: 2000, pp. 2-3). 
A proposta de Pichon-Rivière pode ser estendida à presente pesquisa: como as pessoas relacionaram-se umas com as outras e com a agremiação? O autor auxilia a reflexão com a seguinte definição:

O vínculo é algo diferente que inclui a conduta. Podemos definir o vínculo como uma relação particular com o objeto. Essa relação particular tem como consequência uma conduta mais ou menos fixa com esse objeto, formando um pattern, uma pauta de conduta que tende a ser repetir automaticamente, tanto na relação interna quanto na relação externa com o objeto [...] do ponto de vista da psiquiatria e da psicanálise, aquilo que mais nos interessa é o vínculo interno, isto é, a forma particular que o eu tem de se relacionar com a imagem do objeto colocado dentro do sujeito (PICHON-RIVIÈRE: 2000, p.18).

Pichon-Rivière (2000) postula que o vínculo expõe o consciente e o inconsciente do sujeito. $\mathrm{O}$ autor indicou as patologias que o vínculo poderia trazer para o sujeito em desequilíbrio, quando o objeto interno ou o objeto externo não era alcançado com o equilíbrio esperado. A delimitação dos tipos de desequilíbrio do sujeito foi feita por meio de uma pesquisa sobre a vida do paciente determinando qual fator social (externo) levou ao desequilíbrio interno.

As relações interpessoais estudadas por Pichon-Rivière são as mesmas observadas por Honneth e Fraser. Enquanto o primeiro as compreende como possíveis geradoras de patologias, por enxergá-las pelos olhos da Psiquiatria, os dois últimos compreendem as relações interpessoais como geradoras de soluções para conflitos estabelecidos no meio de vivência.

Neste estudo buscamos entender o que faz com que os indivíduos se vinculem a algo ou a alguém e obtenham benefícios diferentes do monetário. As patologias geradas pelo vínculo quando o sujeito está em desequilíbrio não são objeto de estudo desta pesquisa.

O vínculo não patológico existe quando a relação entre o sujeito e o objeto ocorreram de forma saudável. O estabelecimento do vínculo entre o sujeito e o objeto externo, pode levar o primeiro a comprometer-se com o segundo (Pichon-Rivière 2000).

Somente o ser humano tem a capacidade de interagir com o objeto a que se vincula e de pensar sobre a relação estabelecida. Freire (1981) propõe que apenas o ser humano tem a capacidade de comprometer-se, porque o único ser do reino animal que apresenta capacidade de pensar, de mudar-se e de mudar o que está ao seu redor. 
O autor disse também que o compromisso é uma forma de ser solidário com uma causa e com aquelas que a integram. Quando o homem possui a consciência do compromisso assumido, ele se torna um ser histórico, uma vez que pode mudar a própria história e a história do grupo em que vive (FREIRE, 1981).

O homem exerce seu compromisso e cria vínculos estando e fazendo parte de um grupo, compondo um campo social, onde são estabelecidas as relações sociais. Nesse campo social, o engajamento individual ou coletivo procura manter-se, mas sofre ameaças, incluindo alterações que o tornam mais eficiente ou eficaz (SANTOS, 2005). O indivíduo tem a possibilidade de estabelecer vários vínculos durante a vida.

Ao estabelecer os vínculos, o indivíduo se compromete com objetos e com outros indivíduos relacionados a eles, podendo mudar a si e aos outros. O vínculo e o comprometimento assumidos podem alterar a concepção de vida do indivíduo.

A mudança e a transformação, segundo Ciampa (1987), demonstram que a identidade do sujeito não é limitada, que ela sofre transformações ao longo de toda vida, seja pelo contato com outros indivíduos, por situações as quais o sujeito está exposto, pelo momento da vida do sujeito, pelo sentimento que tem por objetos ou por outras pessoas. A infinidade de possibilidades de comprometimento, de participação e de engajamento demonstram a não finitude do sujeito.

A identidade se forma e se transforma, como diz Ciampa (1987), pelo vínculo e pelo comprometimento do indivíduo com os objetos aos quais ele se relaciona. A escolha dos vínculos e comprometimentos depende do próprio sujeito, ele quem faz as escolhas e sofre as consequências.

De acordo com os conceitos de Pichón-Rivière (2000), o campo social onde os vínculos acontecem é a sociedade capitalista em que vivemos e, neste estudo, o campo social foi a escola de samba, que também foi o objeto externo aos sujeitos (ritmistas e harmonias). Os valores transmitidos nas relações sociais, herdados dos ancestrais de origem negra das agremiações carnavalescas, são os objetos internos nos mesmos sujeitos.

A relação estabelecida entre cada um dos integrantes, os valores e a agremiação causaram transformações que mantiveram cada indivíduo conectado a ela. Os valores absorvidos pelos indivíduos transformaram suas vidas, fazendo com que eles se identificassem com as agremiações. Esses valores foram transmitidos para outros sujeitos e puderam ou não os transformar. A transformação, segundo Ciampa (1987), não é algo radical, 
ou seja, quando a pessoa deixa de ser o que era e passa a ser outro ser, mas sim, algo que ocorreu paulatinamente. A transformação variou de sujeito para sujeito, mas deu-se em todos os que foram expostos a valores diferentes daqueles que possuíam. Essa mudança, nos componentes da bateria e da harmonia, foi intensa, uma vez que o vínculo, a participação e o engajamento mostraram-se visíveis e claros nestes dos grupos. 
Capítulo 3: A ida ao campo de pesquisa - metodologia, descrição densa da vivência em campo e análise dos dados

\subsection{Procedimentos metodológicos}

Entre as diferentes possibilidades metodológicas para a realização de um estudo acadêmico, optou-se pela Etnografia. Os dados foram obtidos em ambiente urbano e foram estudados por meio da Análise de Conteúdo, aplicada quantitativamente nos questionários e qualitativamente nas entrevistas.

\subsubsection{A Etnografia}

O método de pesquisa utilizado nesta pesquisa foi a Etnografia. As teorias de Telmo Caria (2002) e Clifford Geertz (2011) foram empregadas no estudo da relação entre as pessoas e as escolas de samba. Depois, aplicou-se um questionário aos componentes da harmonia e da bateria de três escolas de samba da capital paulistana, pertencentes ao Grupo Especial aquele que recebe mais verbas governamentais, tem o maior número de foliões e apresenta-se no sambódromo do Anhembi. Por fim, foram entrevistados cinco componentes dessas escolas: três da harmonia da Vai-Vai, um da harmonia da Rosas de Ouro e um da bateria da Pérola Negra.

A observação livre dos eventos carnavalescos auxiliou a definição do campo de pesquisa das escolas de samba, permitindo a escolha dos grupos a serem estudados. $\mathrm{O}$ trabalho voluntário era uma questão motivadora a ser respondida desde o início da observação livre, até o desenvolvimento do estudo teórico. A leitura da bibliografia sobre as culturas negras causou um deslocamento no foco inicialmente determinado, após essas leituras, as questões do campo de pesquisa foram reformuladas.

Parte do corpus desse estudo constitui-se a partir de conversas informais com vários interlocutores. A pesquisa foi redirecionada após estas conversas e leituras sobre as culturas negras feitas por Muniz Sodré e Nei Lopes, quando pudemos analisar as observações a respeito dos preparativos do desfile do carnaval de 2012 e 2013.

A primeira ida a campo foi durante os preparativos para o carnaval de 2012. Nesse momento, aplicou-se o questionário aos integrantes da bateria e da harmonia. Ao longo da observação livre realizou-se a sistematização da pesquisa, visualizando-se quais eram os componentes engajados e comprometidos com as funções exercidas. 
Nos preparativos para o carnaval de 2012, foram realizadas quatro das cinco entrevistas da pesquisa. Elas foram desenvolvidas com base em um roteiro semiestruturado, mas também permitiram que os entrevistados falassem de suas histórias. Os entrevistados foram indagados sobre as motivações que os levavam a estabelecer a relação com a escola de samba. A quinta entrevista foi feita com o novo foco de pesquisa, a partir do estabelecimento do eixo "trabalho voluntário".

$\mathrm{Na}$ Etnografia, as observações sobre o objeto de estudo são registradas no diário de campo (GEERTZ, 2011). Esse diário permitiu a análise dos dados obtidos durante o período de 2011 até 2013 e esteve focado no que motivava as pessoas a se engajarem em atividades que não lhes traziam remuneração, nas escolas de samba paulistanas.

\subsubsection{Análise de Conteúdo}

A primeira atividade desenvolvida nas idas ao campo foi o preenchimento de questionários por participantes das escolas de samba, durante a preparação para o carnaval de 2012. Porém, do questionário original que foi preenchido, quatro perguntas puderam ser utilizadas na análise das respostas dadas pelos pesquisados. As demais perguntas estavam diretamente ligadas ao tema que foi modificado ao longo da pesquisa.

Os dados obtidos foram: 159 questionários preenchidos, entre os quais 98 foram respondidos pelos representantes da bateria e 51 pelos componentes da harmonia. Todos foram preenchidos em 2011, no período preparatório para o desfile carnavalesco de 2012.

A base teórica para análise dos resultados adveio de Laurence Bardin (1977), que admite a existência de duas possibilidades de Análise de Conteúdo (AC): a quantitativa e a qualitativa e, algumas vezes, o mesmo conteúdo pode ser analisado das duas formas.

Para a análise das respostas dos entrevistados, outro item constante foi questionado: o tempo de participação na atividade que exerce na escola de samba. Esses questionários foram analisados quantitativamente.

Após o preenchimento dos questionários e a realização da observação livre, optou-se pela realização de entrevistas a fim de conhecer alguns integrantes das agremiações carnavalescas. Foram realizadas cinco entrevistas, a Análise de Conteúdo (AC) foi o método escolhido para a análise. Enquanto nos questionários o aspecto quantitativo foi avaliado, nos questionários, desenvolveu-se a análise qualitativa. 
A partir da articulação entre a Etnografia e Análise de Conteúdo, buscou-se revelar o que leva milhares de pessoas, ano a ano, a engajar-se às agremiações carnavalescas a fim de produzir, ensaiar e atuar do desfile carnavalesco.

\subsection{Descrição densa do trabalho de campo etnográfico e análise dos dados}

O interesse em estudar o carnaval paulistano surgiu em 2004, durante a atividade profissional: naquele ano, consegui um emprego em uma emissora de televisão e fui designada a fazer parte de um grupo direcionado à transmissão do desfile carnavalesco paulistano, do ano de 2005.

Porém desde a infância, os preparativos dos desfiles carnavalescos eram acompanhados, em companhia da mãe e dos irmãos, no período em que eles ocorriam na avenida Tiradentes. Antes da inauguração do sambódromo do Anhembi, cujo nome oficial era Polo Cultural Grande Otelo, todas as escolas do grupo principal desfilavam no domingo e na terça-feira. No domingo, as escolas de samba eram avaliadas. Na terça-feira, o desfile era chamado de apoteose, tratava-se de um desfile descontraído, sem a obrigação de seguir as regras. Atualmente, o desfile também acontece em dois dias: sexta-feira e sábado. Metade das agremiações desfila num dia e a outra metade, no dia seguinte. Durante os dois dias as escolas são avaliadas pelos mesmos jurados, buscando maior coerência na avaliação.

O que era chamado de apoteose, nos tempos da avenida Tiradentes, hoje é conhecido como desfile das campeãs. Essa apresentação acontece na sexta-feira após o feriado de carnaval - que, segundo o calendário católico, acontece sempre na terça-feira. Neste dia, as escolas de samba classificadas entre o primeiro e o quinto lugar no Grupo Especial e as duas primeiras colocadas do grupo de acesso voltam ao sambódromo.

Como foi citado nos Capítulos 1 e 2, o número de componentes das escolas de samba cresceu ao longo do tempo. Segundo conversas informais - ocorridas no período entre 2004 e 2008, com integrantes da escola como José Luiz Oliveira (Zelão), que participava da direção de harmonia da Camisa Verde e Branco na década de 1980 e Raimundo Pereira da Silva (Zulu) - nas décadas de 1970 e 1980, o mínimo de componentes era de 300 foliões, alcançando o máximo de 800 pessoas. 
Além disso, os entrevistados disseram que, mesmo com pequeno contingente nas escolas, com alas que possuíam em média de 20 pessoas, muitas vezes os desfiles avançavam a manhã. O horário não era cumprido e esperava-se muito entre uma escola e outra.

Nos desfiles atuais, mesmo que as agremiações apresentem-se com mais de dois mil componentes (número mínimo exigido pelo regulamento que demarca a disputa entre as escolas de samba $^{18}$ ), às 8 horas da manhã, aproximadamente, a última escola deixa o sambódromo. O regulamento pune quem não cumpre o horário: um ponto a menos por não ter colocado a regra em prática e outro ponto negativo pelo número de minutos que excederam o tempo de desfile da escola ${ }^{19}$.

Os carros alegóricos que encantavam os espectadores, durante os desfiles na avenida Tiradentes, eram montados sobre chassis de fuscas, conforme relatou Raimundo Pereira da Silva, o Mercadoria, diretor de harmonia da Rosas de Ouro na década de 1980, em conversa informal nas preparação para o carnaval de 2011.

Segundo conversa com Delmo de Moraes, responsável pelo barracão da Gaviões da Fiel, os carros alegóricos do carnaval que desfilaram em 2012 foram montados sobre estruturas metálicas semelhantes às usadas na construção de prédios, com reforço e trabalho do equilíbrio de peso nas amarrações dos pontos de ligação de metais.

O comprimento dessas estruturas supera a estrutura de um chassi de caminhão. $\mathrm{O}$ limite da largura do carro alegórico é pouco menor que o da pista de desfile do sambódromo de São Paulo: 12 metros. Muitas alegorias atingiam 14 metros de altura. Os carros alegóricos da década de 2010 são muitas vezes maiores que os da década de 1980.

No período em que as escolas de samba apresentavam-se na avenida Tiradentes, a arquibancada se manifestava a cada nova agremiação que surgia para o desfile. As duas agremiações que faziam a arquibancada tremer - literalmente, uma vez que a estrutura era toda montada em estrutura metálica e madeiras - eram Vai-Vai e Camisa Verde e Branco. Elas eram as que levavam mais componentes, fantasias bonitas e carros alegóricos bem acabados. Por vezes, foram presenciadas brigas nas arquibancadas, entre torcedores das duas escolas de samba, devido às pilhérias e a forte paixão que nutriam pelas escolas.

\footnotetext{
${ }^{18}$ Disponível em: <www.ligasp.com.br/>. Acesso em: 2 nov. 2013.

${ }^{19}$ Disponível em:<www.ligasp.com.br/>. Acesso em: 2 nov. 2013.
} 
Entre o final da década de 1980 até 2003, afastei-me do carnaval. Um dos fatores que determinou essa ocorrência foi o deslocamento para outra cidade, no estado de São Paulo, para a realização da graduação. Após 2003, momento de meu retorno às arquibancadas, no Sambódromo do Anhembi, e de 2004, trabalhando com o tema, o interesse pelo assunto, que se tornou objeto de estudo, deixou de ser latente.

Nesta fase, foram verificadas as obras de referência sobre o tema (Damatta, Cavalcanti, Meyer) e percebeu-se que eram escassas as obras que tratavam do carnaval paulistano. Durante novas pesquisas bibliográficas, localizou-se a obra de Olga Von Simson (SIMSON, 2007) que contém uma pesquisa aprofundada sobre o carnaval paulistano. Concomitante a essas atividades, acompanhou-se o grupo que organizava a transmissão do desfile carnavalesco, em São Paulo. Foi durante esse período que destacou-se um ponto, deflagrador da pesquisa: havia pessoas que desempenhavam funções fundamentais dentro das agremiações de forma não remunerada.

Durante o trabalho de campo, aplicação de questionários e leituras bibliográficas, tendo a atividade não remunerada e o trabalho voluntário como pontos principais, percebeu-se o erro conceitual: não era o trabalho voluntário, definido em Serviço Social, que motivava as pessoas dentro das escolas de samba, mas sim o engajamento, inerente à cultura e à tradição das populações negras que faziam com que os componentes das escolas de samba realizassem as atividades voluntariamente.

A partir da definição de engajamento - entre pessoas negras ou não, que exerciam atividades importantes e fundamentais nas escolas de samba - o retorno ao campo estava direcionado por outras questões.

Em uma escola de samba, durante o ano carnavalesco, há pessoas que trabalham e têm remuneração salarial. Os profissionais remunerados trabalham, especialmente, nos setores de desenvolvimento plástico: para a construção de carros alegóricos eram contratados serralheiros, marceneiros e aderecistas. Costureiras e arrematadeiras recebem remuneração para a produção de fantasias. Os puxadores, responsáveis por cantar os sambas enredo, também eram contratados pelas escolas de samba.

Há funções em que os profissionais poderiam ou não ser remunerados. Nessa situação híbrida, ficam os casais oficiais de mestre-sala e porta-bandeira e os integrantes da comissão de frente. A existência de remuneração dessas funções na escola de samba varia. Há situações em que apenas o casal oficial era remunerado e os demais não recebiam pagamento. No caso 
da comissão de frente, quando havia remuneração, essa era destinada a todos os integrantes, caso contrário, nenhum dos componentes recebia.

\subsubsection{Fases da pesquisa de campo}

Na Etnografia, a ida do pesquisador ao campo é uma das etapas da produção científica, disso resulta a coleta de um farto material que pode traduzir a vivência dos pesquisados. A definição de teorias referenciais e do foco da pesquisa, possibilitou a condução de um trabalho mais objetivo - lembrando-se que um campo de pesquisa pode ser objeto de estudos variados.

Durante as pesquisas de campo, verificou-se que estava sendo realizado um estudo nas duas escolas de samba, que são referência dessa pesquisa, sobre o impacto nas articulações dos joelhos e dos tornozelos para as passistas da Vai-Vai e um estudo que avaliava os problemas auditivos nos ritmistas da Rosas de Ouro, causados pela longa exposição ao som alto da bateria.

A organização da escola de samba também foi alvo de investigação científica quando Tureta (2011) discorreu sobre a atuação dos harmonias nas funções de controle das agremiações. $\mathrm{O}$ autor também apresentou as influências causadas pela interação entre o "nativo" da atividade e o pesquisador, que pode se aproximar da atividade e reverter-se em um nativo. Além disso, ele apresentou a relação que humanos e objetos, (por ele chamados de não humanos), estabelecem no dia do desfile com a mudança da posição do indivíduo frente aos demais. Um exemplo fornecido, foi que o uso de uma camiseta (objeto não humano), pelo autor, levou-o de simples observador a um componente cobrado pelos demais, durante o desfile. Parte das propostas dessa pesquisa foram analisadas por Tureta, porém valendo-se de referencial teórico diverso, o que resultou em outras propostas e conclusões.

A escolha dos harmonias e dos ritmistas como alvo da pesquisa foi resultante das pesquisas de campo. Durante esse período, quando eu atuava como profissional de comunicação, observei e interessei-me por algumas personagens das agremiações, especialmente, o casal de mestre-sala e porta-bandeira, em virtude da dificuldade da função, uma vez que apenas duas pessoas respondiam por um quesito. Esse interesse também foi motivado pela dança apresentada pelo casal, que era diferente daquela elaborada pelos outros 
componentes da escola de samba. As regras de julgamento ${ }^{20}$ determinavam que eles não poderiam sambar, poderiam apenas bailar como se fosse num minueto. A dança do casal de mestre-sala e porta-bandeira emocionou-me. A comissão de frente também poderia ter participado dessa pesquisa, uma vez que é o grupo que abre o desfile, tendo a responsabilidade de causar boa impressão, apresentar a escola e, ainda, aquecer o público.

Ao final, foram escolhidos os grupos de harmonias e ritmistas devido ao forte engajamento e empenho com a agremiação carnavalesca e também pela invisibilidade destes dois grupos durante a apresentação da escola. A situação de invisibilidade do grupo da harmonia foi maior, uma vez que eles somente se destacam quando acontece algum problema durante o desfile - quebra de um carro alegórico, mal estar de algum componente, ou o "buraco", o mais temido dos problemas, que ocorre pela falta de unidade no deslocamento das alas durante o desfile. Além de não ter a remuneração monetária, harmonias e ritmistas geralmente não recebem nenhum elogio particular vindo do público, para suas funções.

\subsubsection{A observação não participante e o despertar do interesse de pesquisar os responsáveis pelo desfile carnavalesco}

Entre os anos de 2004 e 2009, interessou-me as atividades das escolas de samba paulistana e os motivos que levariam as pessoas a frequentar as agremiações e deixarem seus compromissos, suas casas, suas famílias para dedicarem-se a elas. Os questionamentos sobre os motivos que levariam as pessoas ao engajamento foram surgindo em conversas com componentes das escolas, com diretores e presidentes.

As passagens apresentadas a seguir, revelam alguns aspectos importantes para a pesquisa, mas não a constituem, pois não participam do período de elaboração do trabalho de campo, sendo então apresentadas sem datas precisas.

Em uma dessas conversas, durante janeiro de 2007, a presidente da Sociedade Rosas de Ouro, Angelina Basílio, disse que o casal de mestre-sala e porta-bandeira (Luizinho e Sueli) estava ensaiando havia 3 horas e que vinham fazendo isso, todos os dias daquela semana, no período da tarde, sob o escaldante calor de verão. Luizinho e Sueli foram flagrados em ação e fiquei impressionada com tamanho empenho. Mas, o que chamou

\footnotetext{
${ }^{20}$ Disponível em: <www.ligasp.com.br/>. Acesso em: 2 nov. 2013.
} 
atenção foi o fato de que ambos eram voluntários e que a função que desempenhavam junto à escola era um dos quesitos avaliados durante o desfile carnavalesco.

O comentário da jornalista Ariana Camila, componente da Mocidade Alegre, também foi revelador: em virtude dos ensaios e dos desfiles da escola de samba ela tinha perdido um casamento, um noivado e duas provas de segunda fase da FUVEST (vestibular para o ingresso na graduação da USP); mas todas essas perdas valiam a pena pois eram feitas para a Mocidade Alegre (fevereiro de 2008).

Outras circunstâncias que apresentaram a ligação dos componentes com as escolas de samba foram os episódios em que as pessoas acidentaram-se ou colocaram-se em situação de risco, antes ou durante o desfile, para que os carros alegóricos não fossem danificados ou para que eles pudessem entrar no sambódromo.

O relato mais impressionante foi feito por Dalton Ferreira. Ele disse que uma das amigas dele sofrera um acidente e que a moça tinha sido levada ao hospital e "tomado pontos na cabeça". Indagado sobre o motivo do acidente, ele explicou que o grupo de harmonias da Vai-Vai estava coordenando o transporte dos carros alegóricos da escola para as baias, na concentração, dias antes do desfile, quando a amiga do interlocutor percebeu que uma parte da alegoria iria atingir o portão. Para evitar o choque, a moça teria se colocado entre o carro alegórico e a estrutura do portão, tendo a cabeça atingida e cortada, além de ter fícado com dores e tonturas. O que levaria uma pessoa a "arriscar" a vida por causa de um carro alegórico, um objeto inanimado que poderia ser consertado?

Os três eventos citados anteriormente seriam facilmente compreensíveis se acontecessem com pessoas que recebem remuneração. Criados em uma sociedade capitalista, é difícil compreender a motivação da realização de atividades sem remuneração pelos foliões, e ainda com a possibilidade de danos físicos e monetários.

Outro dado que nos chamou a atenção foi o fato de que os ritmistas e os harmonias das escolas de samba possuem um reduzido número de citações nos trabalhos acadêmicos. Assim, o trabalho iniciou-se com a observação livre citada anteriomente, a definição das escolas de samba como cenário da pesquisa, a escolha dos ritmistas e dos harmonias como grupos a serem estudados e a delimitação da pergunta que seria respondida ao longo do estudo: o que leva uma pessoa a engajar-se e a dedicar-se a uma escola de samba, sem ter a remuneração como fim? Com as observações feitas em campo e com o apoio da bibliografia sobre 
carnaval, escolas de samba paulistanas, cultura negra, reconhecimento e engajamento, a pesquisa tornou-se possível.

\subsection{A escolha do método de pesquisa e de análise dos dados}

Apesar de o conceito da cultura negra ainda não estar consolidado nas atividades iniciais desse projeto, percebeu-se que, nas escolas de samba com menor contingente de afrodescendentes, as notas nos quesitos harmonia (canto), evolução (dança e deslocamento) e bateria (ritmo) eram menores que em agremiações que possuíam maior número de afrodescendentes. Com base nestas informações e durante a sistematização da pesquisa, foram escolhidas três escolas para serem acompanhadas e pesquisadas: Vai-Vai, Rosas de Ouro e Pérola Negra. Entre as escolas de samba escolhidas, a primeira possuía o maior número de componentes afrodescendentes. A segunda foi criada em uma região que possuía muitos afrodescendentes, mas, ao mudar a sede de lugar, perdeu grande parte destes componentes. A última era a que tinha o menor número de afrodescendentes. Mesmo que esse dado quantitativo tenha despertado interesse (quantidade de afrodescendentes em cada agremiação), a importância das culturas negras foi revelada durante a pesquisa.

Nessa fase, anterior ao trabalho de campo, entramos em contato com a Antropologia, por meio das referências bibliográficas e em aulas do Departamento de Antropologia da USP. Com base nas aulas e nas leituras, percebeu-se que o método que melhor se adaptava às intenções dessa pesquisa era a Etnografia. Segundo Telmo Caria (2002) e Clifford Geertz (2011), a Etnografia é a absorção e a vivência do modo de viver, de ver, de entender e de interpretar o mundo, segundo o ponto de vista do pesquisado. Para isso, o pesquisador precisa despir-se de seus conceitos e, sem preconceito, absorver o máximo da vida da população estudada.

Caria (2002) sugere ainda que a Etnografia mostra-se um instrumento de estudo das sociedades urbanas, sendo feita por pesquisadores e pesquisados urbanos. Aquilo que ocorria anteriormente, do pesquisador viver em grupos com pouco ou nenhum contato com o mundo “civilizado", não ocorre mais no século XXI pois a grande maioria dos povos foi mapeada, estudada e desvendada. Agora, o objetivo do trabalho de campo seria entender, conhecer, compreender e estudar o que estava ao alcance da mão, do olhar, do sentir e do cheirar: a sociedade em que se vive e que, muitas vezes, não é compreendida pela população que a 
compõem. Desde o século XX, a Etnografia desenvolve trabalhos com grupos minoritários da sociedade em que vive o pesquisador.

Apresentou-se um questionário aos pesquisados, durante o trabalho de campo. O questionário desta pesquisa foi produzido para ter resultados quantitativos, dessa maneira, a Etnografia não seria o método mais eficaz para analisá-los, por isso, escolheu-se a Análise de Conteúdo para fazê-lo. Laurence Bardin (1977) propõe que a Análise de Conteúdo pode valerse de farto e diversificado material, retirado de revistas, jornais, entrevistas, questionários, sessões de psicanálise, entre outros.

Nesta dissertação, a análise dos questionários e de entrevistas deu-se pela organização das respostas segundo tópicos, temas, palavras, frases, expressões. Visualizamos assim, na resposta dos pesquisados, os pontos coincidentes e os não coincidentes com as teorias que embasam esta pesquisa (BARDIN, 1977).

\subsection{A ida a campo}

O trabalho de campo foi desenvolvido a partir de junho de 2011, quando as agremiações iniciaram as atividades do ano carnavalesco, com os ensaios da bateria, como na Pérola Negra, a festa de lançamento do enredo, no caso da Vai-Vai e da Rosas de Ouro.

As atividades de observação foram iniciadas na escola Rosas de Ouro. Durante dois anos, em junho de 2010 e 2011, a festa de apresentação do enredo da escola (tema do desfile carnavalesco) foi acompanhado.

Foram duas apresentações grandiosas que tiveram a participação voluntária de mais de 300 pessoas, entre figurantes do espetáculo teatral, ritmistas e harmonias. Os primeiros atuaram nas apresentações, com ensaio prévio, os ritmistas foram responsáveis pela música executada antes do espetáculo, quando foram cantados o hino da escola, o samba-exaltação e o samba-enredo do ano anterior. Durante a apresentação, os ritmistas guardaram os instrumentos e juntaram-se aos convidados para assistir ao espetáculo.

Os harmonias foram os responsáveis pela organização do evento, participando, anteriormente, de ensaios do espetáculo. No dia do evento, os harmonias chegaram antes para organizar mesas e cadeiras no espaço da quadra da agremiação. Depois disso, alguns se dispuseram a controlar o local em que as pessoas iriam sentar-se, outros ficaram responsáveis por receber o pavilhão (bandeira) de agremiações convidadas e outra parte do grupo responsabilizou-se pelo apoio ao espetáculo. 
Após o término da festa, que durou cerca de três horas, os harmonias, exaustos, abraçaram-se e cumprimentaram-se porque a organização tinha sido satisfatória. Mas, antes dos abraços, muitos olhares tensos, gritos e sinais foram realizados entre eles, a fim de realizar da melhor maneira o que fora planejado.

A tensão no rosto dos harmonias que se dedicavam à organização foi observada ao longo do espetáculo. A cada pavilhão que adentrava a quadra, eles se mobilizavam para seguir o protocolo, determinando que um casal de mestre-sala e porta-bandeira da escola anfitriã recebesse o casal com o pavilhão da escola visitante. Para que esse encontro acontecesse, os harmonias abriam espaço entre as pessoas presentes na quadra, criando um corredor, de maneira a permitir que os representantes e o símbolo da agremiação convidada fossem recebidos pelos representantes e pelo símbolo oficiais da escola de samba anfitriã.

Depois da cerimônia de abertura do evento, em que o hino, o samba-exaltação da escola, o pavilhão e o samba do ano anterior foram mostrados, com a participação da bateria, a festa de apresentação do enredo começava.

Enquanto os ritmistas deixavam seus postos para participar da festa, os harmonias seguiam tensos, na organização do evento. O grupo dos harmonias ficou responsável pelo controle da entrada dos figurantes, como uma peça em um teatro de arena: os figurantes representavam os diferentes momentos dos enredos apresentados. A tensão no rosto e no olhar dos harmonias explicava-se pela responsabilidade por eles assumida, de organizar e controlar uma festa com mais de mil pessoas na plateia e mais de 300 figurantes no espetáculo.

Na Vai-Vai, também foi verificado o lançamento do enredo do carnaval de 2012. De forma mais modesta, havia 300 pessoas envolvidas, entre convidados, componentes da escola, ritmistas e harmonias. Neste evento, não houve espetáculo, mas a leitura da proposta que a agremiação pretendia apresentar no sambódromo no ano seguinte. Apesar de singelo, durante o evento foram executados o hino da escola, o samba-exaltação e o samba-enredo ano anterior, com o apoio dos ritmistas.

Mesmo para um evento de proporções menores que o observado na Rosas de Ouro, o grupo de harmonias era grande e fazia-se notar. Durante a chegada ao local do evento, observou-se que os harmonias carregavam e organizavam mesas e cadeiras de maneira a evitar a ocupação da parte central da quadra da escola, visando à apresentação do casal de mestre-sala e porta-bandeira. Com a chegada dos convidados para a apresentação, o espaço deixado livre foi sendo ocupado. Mas, no momento em que a festa começou, os harmonias 
pediram que as pessoas deixassem o centro e ocupassem os espaços vagos disponíveis na quadra para que o primeiro casal pudesse apresentar-se. Os presentes afastaram-se sem muita resistência e a festa começou.

Nesse dia, foi presenciada uma cena que revelou a dimensão da importância do pavilhão para a escola de samba. O primeiro casal de mestre-sala e porta-bandeira, responsáveis por dançar com o pavilhão da Vai-Vai, apresentou-o ao mestre de bateria, que o reverenciou e mostrou-o para o restante da bateria que abaixou a cabeça, em sinal de respeito. Um dos ritmistas estava usando um boné e foi repreendido aos brados pelo mestre de bateria, que o obrigou a retirar o objeto da cabeça. De cabeça baixa e sem reclamar ou retrucar, o rapaz fez o que foi pedido. Ele ficou bastante nervoso, muito envergonhado, mas seguiu tocando o instrumento.

Ele demonstrou respeito a dois ícones dentro da escola: ao pavilhão e ao mestre de bateria. Como dito anteriormente, o pavilhão representa a escola de samba, possuindo um caráter sacro e místico e o mestre de bateria é responsável por um dos quesitos mais celebrados na escola. O rapaz em questão era um jovem, que possuía aproximadamente 20 anos. Era alto e forte, apesar de parecer muito jovem, o que contrastava com a figura do mestre de bateria, um homem com mais de 60 anos. Observamos o conflito vivenciado pelo jovem rapaz. As expressões faciais demonstravam que ele passava por um turbilhão de emoções: o orgulho de tocar numa bateria com renome no carnaval paulistano, a vergonha de ser repreendido diante dos demais e a responsabilidade em seguir tocando, sem sair do ritmo.

Tentamos falar com o rapaz durante o preenchimento dos questionários, mas ele não ele não quis participar e dessa forma, não foi possível conversar sobre o fato acontecido poucos momentos antes. Estava irritado, era visível.

A postura assumida pelo rapaz, de calar diante da repreensão e de manter-se na função designada, é observada quando a pessoa apresenta-se em ambiente de trabalho e é remunerada ou quando, sendo participante de alguma religião, a pessoa é repreendida por um superior hierárquico. Em ambientes lúdicos e voluntariosos, a expectativa era de que a atitude do rapaz fosse de deixar o ambiente em que ocorria a situação insólita e vexatória. Mas, por que ele não o fez? Por que não saiu? Essa dúvida perdurou nesse momento da pesquisa.

No mesmo dia, antes da leitura do enredo para 2011, foram observadas três senhoras idosas sentadas em um ponto da quadra. Era perceptível que estavam em um espaço reservado para o grupo das baianas da escola e que trocaram cumprimentos com outras componentes da 
ala e também com algumas pessoas que chegaram à quadra da Vai-Vai, no bairro da Bela Vista, na região central da capital paulista. $\mathrm{O}$ fato que mais chamou a atenção foi o início do evento, quando primeiro casal de mestre-sala e porta-bandeira apresentou-se. Depois que o primeiro casal de mestre-sala e porta-bandeira apresentou o pavilhão, primeiro para o presidente da escola e depois para o mestre de bateria, o símbolo máximo da escola foi conduzidos até as três senhoras, que o reverenciaram. Mesmo com dificuldades, as três puseram-se em pé e beijaram o pavilhão, solenemente.

Mais uma vez, questionou-se o porquê daquelas senhoras, que poderiam estar confortavelmente em suas casas, deixarem seus lares e dirigirem-se para a quadra da escola, em uma noite fria de inverno do mês de junho de 2011. O que levaria as pessoas a deixarem suas casas em noites frias para ouvirem um falatório, em vez de ficarem no aconchego do lar?

Ao final da festa, os ritmistas foram guardar os instrumentos rapidamente. Quase foi perdida a oportunidade do preenchimento dos questionários. Se não fosse a ajuda do mestre de bateria, nenhum ritmista teria participado da pesquisa.

$\mathrm{Na}$ escola de samba Pérola Negra, acompanhou-se o primeiro ensaio da bateria da escola, em uma noite fria de junho de 2011. Mesmo assim, 32 ritmistas, além do mestre de bateria, compareceram à quadra da escola, no bairro de Vila Madalena.

Era o segundo ano consecutivo de Anderson Luiz Paulino, o mestre Bola, no comando da bateria. Foi possível verificar que, no primeiro encontro, ele corrigiu uma sequência rítmica (bossa) anterior e transmitiu uma nova sequência para o grupo.

Por ser um evento ainda mais intimista, foi possível observar a tensão e a satisfação no rosto de cada um dos ritmistas ao receberem elogios do mestre de bateria. Era visível a alegria do grupo em estar naquele lugar, mesmo naquela noite fria. Todos tocavam sorrindo e uns brincavam com os outros. Mesmo prestando atenção nas determinações do mestre, eles demonstravam descontração ao executar as batidas nos instrumentos que carregavam. Cerca de 10 pessoas participavam do ensaio. Ao final do reunião, o carnavalesco André Machado comentava, com os compositores de samba-enredo, a sinopse, usada como base das músicas que seriam compostas para concorrer ao samba-enredo da escola. Esta reunião não foi acompanhada porque, diferentemente daquilo que ocorria nas décadas de 1970 e 1980, os compositores não eram da escola. Eles formaram grandes grupos, com integrantes de várias escolas e concorriam com sambas enredos em várias escolas. Esse grupo e a nova forma de fazer samba-enredo não foram estudados nesta pesquisa. 


\subsection{A inserção no campo de pesquisa}

O campo de pesquisa não foi algo novo para mim. Cerca de quatro anos, antes de sistematizar a pesquisa, tive acesso a ele, o que causou o reconhecimento pelos integrantes das escolas de samba. Era vista como uma profissional que realizava a cobertura jornalística do desfile de escolas de samba. Durante a pesquisa de campo, atuando como pesquisadora e não profissional da imprensa, busquei as figuras centrais nas escolas predeterminadas, que facilitaram a chegada ao público alvo.

Mesmo tais facilitadores tiveram dificuldades para compreender os propósitos da pesquisa, realizada com questionários impressos e canetas nas mãos, objetivos diferentes daqueles da transmissão televisiva. Eles não dificultaram minha entrada no campo de pesquisa, mas fui apresentada como uma profissional vinculada à empresa de comunicação. No momento em que tive oportunidade, e também no questionário, expliquei que tratava-se da busca de respostas para questões de cunho acadêmico.

Alguns, inclusive os facilitadores, perguntaram o motivo que me levou a voltar a estudar, questionando se este estudo tinha algum vínculo com a empresa em que eu trabalhava e, se me ajudaria a receber salários melhores. Respondi às perguntas e, muitas das respostas ampliaram as dúvidas deles. Muitos questionaram o porquê do comprometimento com algo "desnecessário" se a pesquisa não estava relacionada ao aumento salarial, nem à mudança de cargo na empresa.

A resposta foi que a pesquisa me satisfez pois permitia a expansão de meus limites e também possibilitava o encontro com uma atividade a qual eu estava afastada há anos. Os interlocutores e os pesquisados demonstravam ainda mais dúvidas do que antes da resposta. Era evidente que não conseguiam entender o porquê de fazer algo sem buscar, nenhum benefício, fosse ele financeiro ou material.

No primeiro período, entre 2004 e 2010, antes da sistematização deste estudo, as escolas de samba eram consideradas possíveis cenários de pesquisa e os grupos dos harmonias e ritmistas poderiam ser estudados. No segundo período, entre 2011 e 2013, com a pesquisa sistematizada, observou-se o empenho, a entrega e a dedicação de harmonias e ritmistas.

Durante a observação não participante dos eventos junto às escolas de samba verificamos que mesmo tendo uma festa como objetivo, os dois grupos realizavam as tarefas como profissionais remunerados: com seriedade e compenetração.Verificou-se ainda que, 
tanto entre afrodescendentes e pessoas de outras origens étnicas, os fundamentos da cultura negra estavam fortemente presentes, apesar da heterogeneidade da constituição física, o grupo estava unido por um sentimento de pertencimento à escola de samba, emanando alegria e os unindo na realização dos afazeres.

\subsubsection{A dificuldade da realização da observação não participante}

Em virtude da atividade profissional desempenhada, o contato com as escolas de samba deu-se, anteriormente ao período da pesquisa. Este fato permitiu a participação nos eventos das agremiações, o que me tornou conhecida pelos componentes das escolas de samba.

O significado do pavilhão conduziu a pesquisa do trabalho desenvolvido pelos casais de mestre-sala e porta-bandeira. Com isso, muitas vezes durante ensaios ou mesmo no dia do desfile principal, desenvolveu-se duas coisas ao mesmo tempo: o acompanhamento da agremiação até o final do desfile, na dispersão, para que pudessem ser geradas as informações sobre os pontos cegos para as equipes da transmissão do evento, depois do espaço destinado ao recuo da bateria; e também o primeiro casal ou casal oficial era acompanhado do lado de fora da pista de desfile, com incentivos e gesticulação, além de conversas com o casal ou com o apresentador sobre as reações dos jurados. Esta atitude, parecia ser mais uma superstição do que algo eficaz, já que essas ações, muitas vezes, não podiam ser observadas pelo casal, em virtude da grande concentração do momento.

Nos dois anos em que a pesquisa foi realizada, não foi possível acompanhar o casal de uma das escolas como se fazia sistematicamente em período anterior. Mas não deixamos de verificar a formação de um grande buraco à frente do casal da Pérola Negra, em 2012, quando nossa atividade era a de pesquisa e não a de observadora e incentivadora do casal.

Por pouco não avisamos a um dos harmonias, porque da forma como se desenvolvia o evento, a agremiação iria perder notas em evolução, em harmonia e em casal de mestre-sala e porta-bandeira - e as piores notas da escola, em 2012, tinham sido nesses quesitos. O casal teve uma penalização leve, uma vez que o jurado julgou a dança e a apresentação e não os esforços para a contenção do buraco que tinha se formado durante o desfile. Também não avisamos os harmonias, sobre as pessoas que não estavam cantando ou que não desfilavam demonstrando empolgação. 
$\mathrm{Na}$ Rosas de Ouro, o casal não era acompanhado. Na concentração, tivemos que nos conter para não avisar os harmonias e os chefes de alas sobre erros na montagem de fantasias, pessoas que não estavam cantando, que estavam desanimadas, que empunhavam máquinas fotográficas ou que não estavam atentas àquilo que iriam desempenhar em instantes.

$\mathrm{Na}$ Vai-Vai, durante o carnaval de 2012, tive muita dificuldade para não participar do desfile da escola. Naquele ano, um reality show criado por um dos programas da empresa em que trabalhei levou dois repórteres a desfilarem como casal de mestre-sala e porta-bandeira. Por isso, participei da reunião de apresentação do casal para os dirigentes da agremiação, em que ambos os lados expuseram o que queriam e o que poderiam dar ou não. Participei também do primeiro contato dos dois repórteres com a comunidade da escola de samba. Acompanhei o primeiro ensaio técnico da escola de samba, em que o par de colegas de trabalho apresentou-se na função de casal de mestre-sala e porta-bandeira. Por fim, no dia do desfile, verifiquei a evolução dos colegas de trabalho, que poderiam ou não prejudicar a harmonia da escola, caso fizessem algo diferente daquilo que lhes fora ensinado. Os dois repórteres saíram-se muito bem e não atrapalharam a escola na evolução e na harmonia.

O que é a observação não participante e por que é tão difícil de realizar? Segundo Tureta (2011), a observação não participante ocorre quando o pesquisador coloca-se como um mero espectador dos fatos que analisa. Nessa situação, o pesquisador, apesar de estar frente a frente com os fatos que vai analisar, não reage ao que vê, ouve ou sente e não interage com os atores que observa. Apesar de estar inserido no campo de pesquisa, o pesquisador procura não interferir no agir dos pesquisados.

Percebeu-se que mesmo quando o comportamento do pesquisador busca não alterar o campo de pesquisa, o simples fato da existência da presença do pesquisador gera impactos. Verificou-se que o pesquisador sempre influencia o campo que se dispõe a estudar, mesmo que de maneira não intencional. Os pesquisados modificam-se, em diferentes graus, com a entrada de um estranho pesquisando o seu meio. Essa constatação indica que o observador pode não ser atuante, mas a presença dele o constitui como um participante do meio que estuda. Tendo isso em vista, a não participação seria possível somente caso a observação ocorresse fora do meio, usando-se câmeras de vídeo, sem o conhecimento dos pesquisados. 


\subsection{O preenchimento dos questionários}

Em 2011, o questionário que foi aplicado em campo apresentava perguntas sobre o trabalho voluntário - aspecto central dessa pesquisa. Na escola de samba Vai-Vai, os ritmistas preencheram os questionários no dia da apresentação do enredo para o Carnaval de 2012, como foi relatado anteriormente; os ritmistas da Rosas de Ouro foram abordados no primeiro dia do ensaio, em junho de 2011; e os ritmistas da Pérola Negra receberam os questionários no primeiro ensaio.

Os ritmistas podem ser abordados em dias de ensaios porque formam um grupo compacto e a interpelação torna-se mais simples, uma vez que os três mestres de bateria auxiliam a mediação, pedindo para que todos preenchessem os questionários.

Para o grupo de harmonias, a estratégia usada foi outra. Primeiro o responsável pelo grupo foi contatado. Depois disso, dirigiu-se à quadra das escolas de samba em dias de reunião dos harmonias e, quando o evento terminava, o diretor de harmonia auxiliava o trabalho, solicitando o preenchimento dos questionários.

Os ritmistas, muitos deles ainda adolescentes, preencheram os questionários rapidamente. O grupo era inquieto, sempre com comentários jocosos e engraçados. Os harmonias formavam um grupo com menos pessoas, a maioria na fase adulta, mais quietos e compenetrados. Responderam aos questionários com mais critério, mais atenção e compenetração. Mesmo com a diferença na forma de agir entre os grupos, o preenchimento dos questionários foi satisfatório.

\section{Entrevistados}

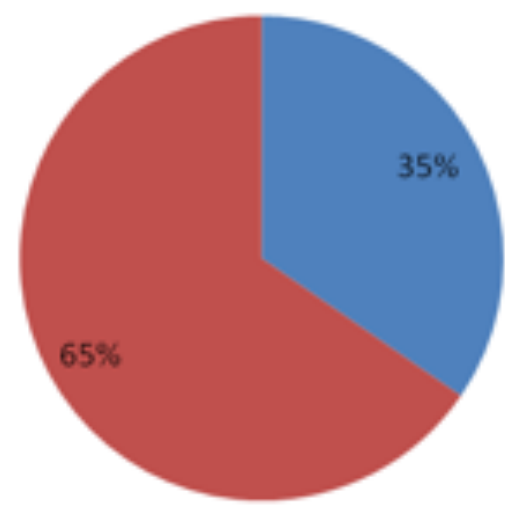

= Harmonias

Ritmistas

Figura 1: Divisão de funções entre os participantes que preencheram os questionários. 
O questionário propunha quatro perguntas de múltipla escolha - que não vão ser analisadas pois relacionam-se ao trabalho voluntário, premissa alterada no desenvolvimento deste estudo.

Foram realizadas perguntas diretas sobre a identificação dos pesquisados (nome, idade, etnia) e também sobre a ligação do pesquisado com a escola de samba (função, há quanto tempo participa das atividades, em qual escola de samba começou e, por que foi para a escola de samba). Ao todo, 159 questionários foram preenchidos, destes, 54 por harmonias e 102 por ritmistas.

Alguns ritmistas e também harmonias perguntaram se o questionário era um item de nossa atividade profissional. Com a resposta negativa, a pergunta seguinte foi: se não é profissional, nem para render dividendos, quais eram motivos que levaram para uma escola de samba, no mês de junho? As perguntas dos entrevistados foram interessantes pois demonstraram compartilhamento de curiosidade, o questionamento aconteceu dos dois lados do estudo, e por coincidência, a mesma pergunta foi feita entre os envolvidos: tanto interlocutores, ritmistas e harmonias, quanto a pesquisa, queríamos saber quais seriam os motivos que condicionaram o engajamento às escolas de samba.

\subsubsection{Personagens inesperados}

Durante a espera pelo retorno das folhas dos questionários, um dos harmonias da VaiVai aproximou-se e iniciou uma conversa. Ele queria saber quais eram as motivações para a aplicação do questionário. Após explicar que se tratava de um estudo sobre a atuação de harmonias e ritmistas nas escolas de samba, o harmonia nos parabenizou e revelou que era professor de matemática em escolas da periferia da capital paulista e que havia começado dois mestrados. Contou que uma das fórmulas matemáticas que vinha tentando desenvolver foi analisada por um estudioso indiano, um dos mais importantes matemáticos do mundo. Explicou, com orgulho e com brilho nos olhos, que tinha sido corrigido por uma figura renomada. Ele comentou, também, sobre o respeito que os alunos tinham por ele.

Este respeito demonstrado pelos alunos também foi observado durante os ensaios técnicos e nos desfiles coordenados pelo grupo de harmonias da escola. Quando o professor comentava sobre as atividades na Vai-Vai, a fala dele também era emocionada. Ele disse que, apesar das várias atividades exercidas, não largava a Vai-Vai: criava os filhos dentro da escola de samba, a partir dos valores da família do samba. 
Outro harmonia aproximou-se e demonstrou alegria por termos escolhido a Vai-Vai como um dos campos de pesquisa. Enquanto ele conversava conosco, várias pessoas vieram abraçá-lo e falar palavras de conforto. Questionamos o que havia acontecido e ele disse que uma irmã dele havia morrido e que as pessoas da agremiação tinham sido importantes para que ele superasse a perda e assim sentia-se forte para voltar à harmonia da agremiação.

A Pérola Negra não realizou festas para divulgar os enredos dos anos 2012 e 2013. Mas, uma personagem chamou a atenção da pesquisadora, pois ela tinha sido entrevistada anteriormente, durante a atividade profissional da pesquisadora e sabíamos da história de vida dela. Por isso, fomos surpreendidas com a sua chegada para tocar na bateria. Essa componente trabalhava como costureira no barracão da escola. Ela não era uma profissional que trabalhava fora e enviava o produto do trabalho para o barracão, era uma das responsáveis pela confecção das fantasias das três alas que as escolas de samba não comercializavam: baianas, crianças e bateria.

No dia em que os questionários foram preenchidos na quadra da escola, ela nos respondeu que além do trabalho no barracão, em que era remunerada como costureira, também tocava ganzá, popularmente conhecido como chocalho, na bateria da escola. A personagem citada fazia mais do que o salário que recebia: costureira dedicada durante o dia e ritmista da escola à noite.

\subsubsection{A alegria disciplinada dos ritmistas e a disciplina ritmada dos harmonias}

Os dois grupos que foram a base deste estudo tiveram atitudes bastante distintas durante os ensaios. No dia do desfile, a tensão do enfrentamento de um julgamento, os fez agir semelhantemente.

Antes do desfile oficial, porém, a atitude de harmonias e ritmistas foi bastante diversa. Enquanto os harmonias compareciam em peso aos primeiros ensaios, os ritmistas demoraram um pouco mais a aparecer, integrando-se às atividades das agremiações no período da escolha do samba-enredo.

Os questionários foram aplicados no início do ano carnavalesco, período em que os ritmistas não estavam totalmente integrados às atividades da escola. Em virtude disso, a ala rítmica das agremiações pesquisadas foi responsável por 102 dos questionários preenchidos. Um número que pode ser considerado baixo, uma vez que cada uma das baterias pesquisadas apresentava aproximadamente 230 ritmistas durante o desfile carnavalesco. 
A bateria apresenta-se como um grupo forte dentro da escola de samba. Como exemplo do poder que tinham no jogo de forças das escolas de samba, durante os preparativos para o carnaval de 2013, os ritmistas de uma das escolas de samba pesquisadas fizeram uma paralisação e não tocaram em um dos ensaios da escola. Eles demonstravam insatisfação com um incidente acontecido dias antes. O movimento foi tão organizado e poderoso, que a escola devolveu o dinheiro do ingresso para os foliões que participaram do ensaio. Apesar do poder que detêm, por serem o coração da escola de samba, os ritmistas ensaiam sempre sorrindo, brincando, paquerando e divertindo-se. Não economizam gargalhadas, galhofas e sorrisos quando aprendem algo novo ou corrigem algo que erraram anteriormente.

Apesar de existirem componentes experientes, foram identificados 17 pessoas com mais de 20 anos de idade, atuando na função de ritmista, entre as 102 pessoas que preencheram os questionários.

A idade limite para considerar alguém jovem varia de acordo com a fonte consultada. Enquanto o IBGE diz que a juventude vai até os 24 anos - o que resultaria em 55 ritmistas jovens $^{21}$ - o Conselho Nacional da Juventude ${ }^{22}$ diz que a juventude abrange o intervalo entre os 18 e os 29 anos de idade - resultando em 49 jovens, conforme mostra o gráfico abaixo.

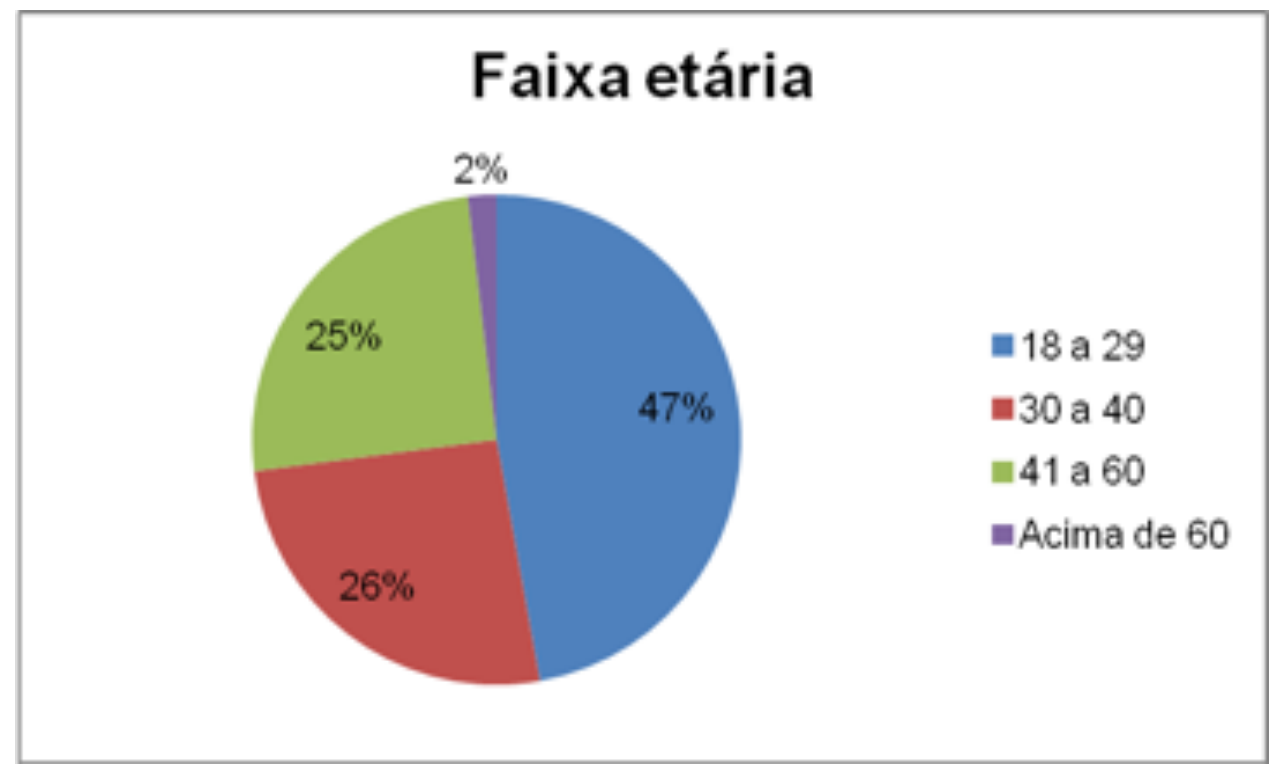

Figura 2: Faixas etárias presentes nos setores estudados.

\footnotetext{
${ }^{21}$ Disponível em: <www.ibge.gov.br/home/estatistica/populacao/populacao_jovem_brasil/comentario1.pdf>. Acesso em: 2 nov. 2013.

${ }^{22}$ Disponível em: <www.juventude.gov.br/sobre-a-secretaria/view>. Acesso em: 2 nov. 2013. Disponível em: $<$ www.ligasp.com.br/>. Acesso em: 2 nov. 2013.
} 
Para identificar os grupos descritos, jovens e experientes, foram usados dois padrões diferentes, entre os ritmistas. A idade foi a referência quando se tratava de determinar se o ritmista era jovem. Já o tempo de atuação na função do ritmista foi parâmetro utilizado para a determinação da experiência. Ambas opções estavam disponíveis nos questionários.

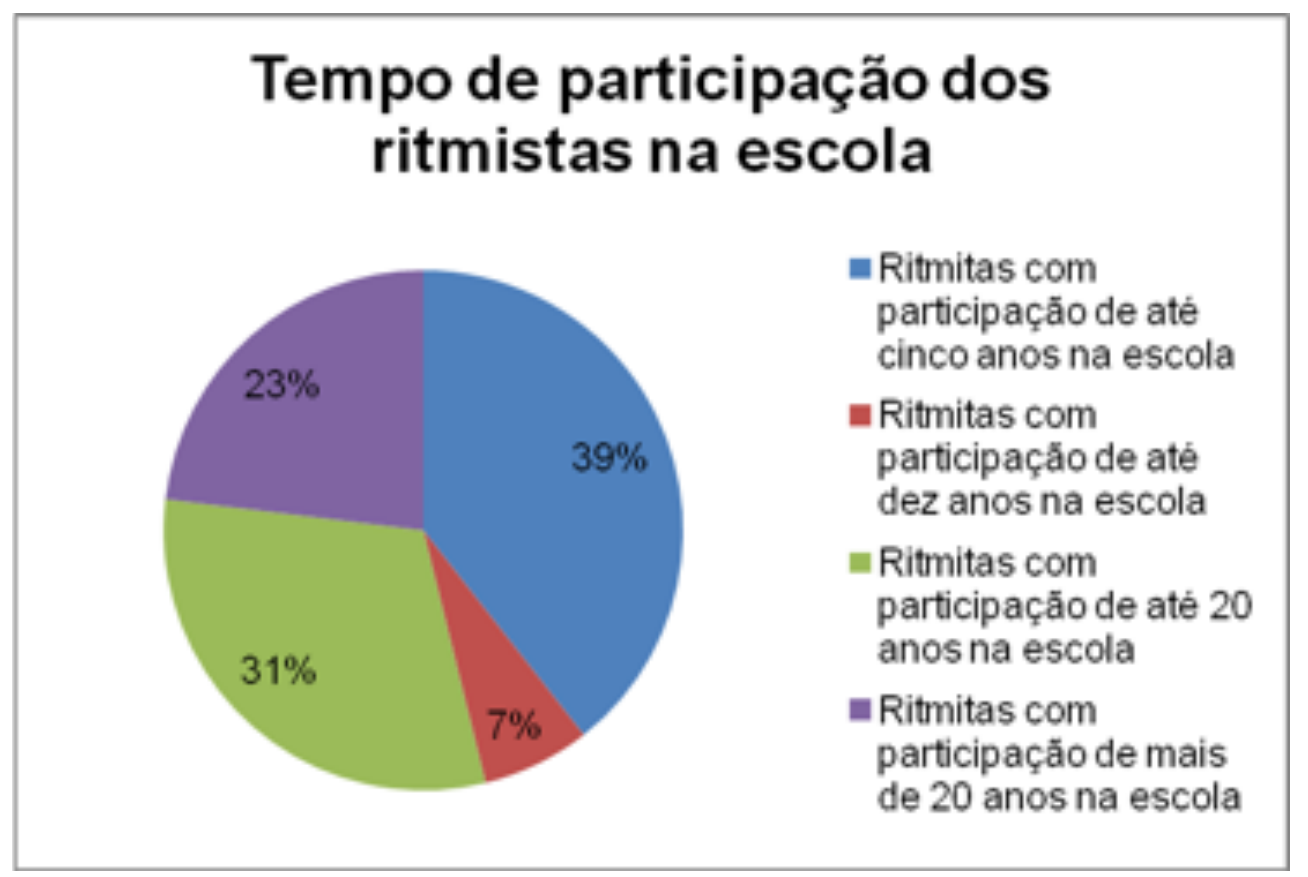

Figura 3: Permanência na função desenvolvida na escola de samba.

Os ritmistas chegam cerca de meia hora antes do início dos ensaios. Antes da chegada do grupo maior, os auxiliares do mestre de bateria, ou o próprio mestre, afinam os instrumentos, verificam se não existe a necessidade de trocar o couro, que foi substituído por uma película plástica, ou outras partes dos instrumentos. O grupo dos ritmistas retira os instrumentos e as baquetas (hastes de madeira) que são distribuídas pelos auxiliares do mestre de bateria e segue para o espaço a eles reservados, sempre nas proximidades do palco, onde ficam os puxadores dos sambas.

$\mathrm{O}$ mestre de bateria precisa dos auxiliares para que os seus comandos, à frente da bateria, sejam vistos por todos os integrantes da bateria, desde os ensaios até o dia do desfile. Os auxiliares também são os responsáveis pelo ensino dos instrumentos aos novos ritmistas.

O grupo de harmonias é mais sisudo, mais estrategista. Eles estão sempre concentrados, atentos e prontos para resolver imprevistos. Os harmonias chegam cerca de uma hora mais cedo para organizar a quadra para o ensaio. Eles acompanham a disposição e orientam o que deve ser observado pelos seguranças que foram contratados para o evento, 
conversam com os auxiliares e com o mestre de bateria para saber se o grupo vai realizar alguma ação ou coreografia diferenciada que precise de auxílio na organização, além disso, comunicam-se com os casais de mestre-sala e porta-bandeira, que se apresentam no início do ensaio. Os harmonias são responsáveis, nas três escolas estudadas, pela abertura de espaço, no meio da multidão, para que os casais dancem ostentando o símbolo máximo da escola de samba.

A Rosas de Ouro, segundo relato do diretor de harmonia da escola, tem um departamento separado para cuidar dos casais. Eles fornecem água, impedem que desavisados atrapalhem a dança do casal nos ensaios, ou que toquem o pavilhão que fica exposto em local de destaque, durante o evento na quadra. No dia do desfile, este departamento também ajuda a montar e vestir a fantasia dos casais, que são formadas por várias partes para facilitar o transporte. Na Vai-Vai e na Pérola Negra este é um atributo do grupo de harmonias.

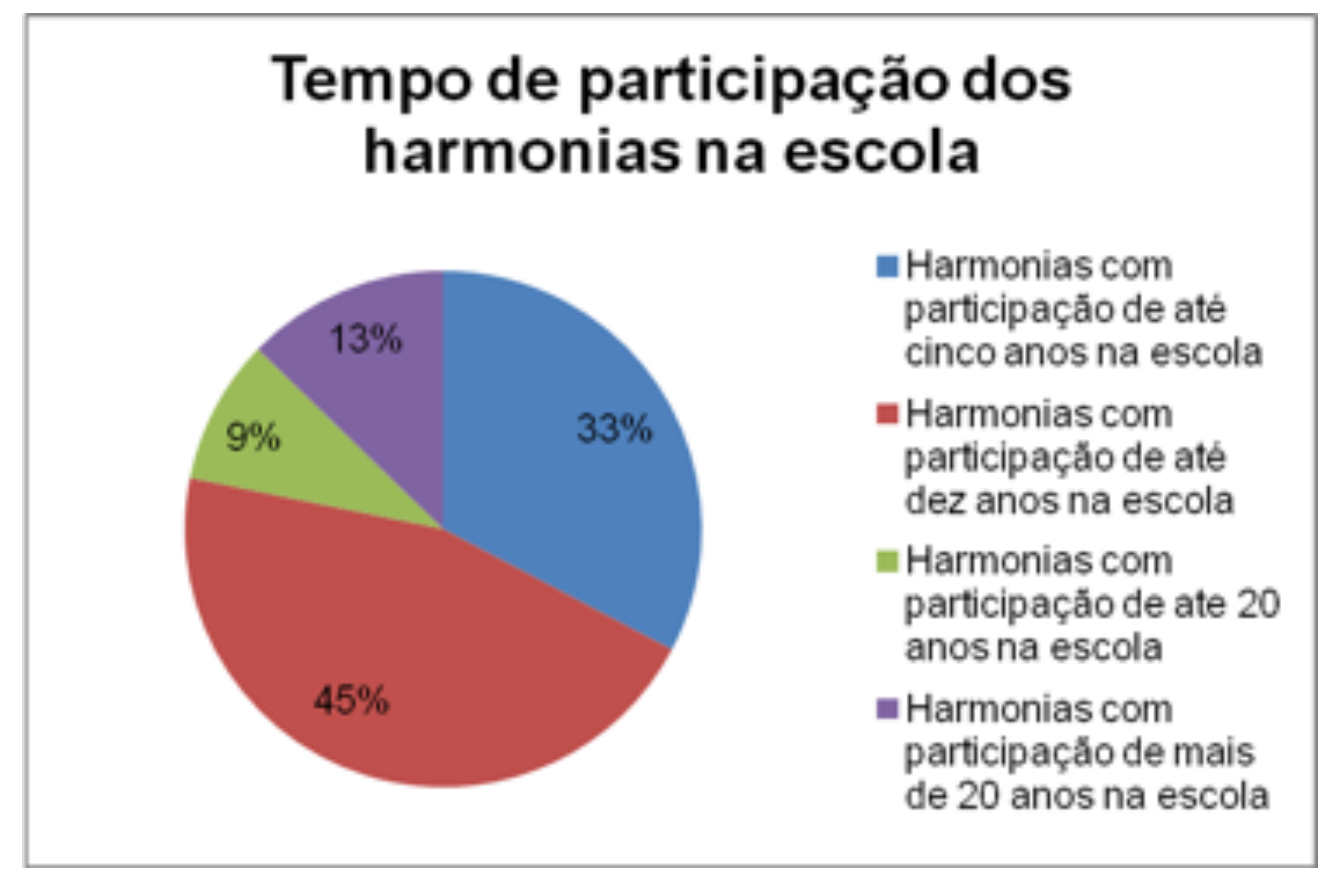

Figura 4: Permanência na função desenvolvida na escola de samba.

A responsabilidade sobre o grupo de harmonias era grande e variada. Mesmo que também fossem animados, empolgados e prontos a agir, eram menos sorridentes e estavam sempre compenetrados.

Nos ensaios técnicos e no dia do desfile, harmonias e ritmistas encontravam-se no sambódromo do Anhembi. Enquanto os ritmistas eram os responsáveis por manter o ritmo da música que foi cantada, o mestre de bateria e os auxiliares encarregavam-se de transmitir aos 
ritmistas as mudanças temporárias na forma de tocar, conhecidas como breques ou paradinhas; os harmonias preocupavam-se em manter o grupo rítmico (ou bateria) alinhado. Eles preocuparam-se, também, com elementos externos à apresentação da agremiação, como fotógrafos e cinegrafistas, evitando que eles seguissem de forma desordenada, atraídos pelas rainhas de bateria, e que não atrapalhassem o deslocamento do grupo rítmico e da escola de samba.

O ponto crítico do desfile era o recuo da bateria. O grupo de harmonias era o responsável pela "parada" da escola. Este parar significava reduzir ao máximo o deslocamento dos foliões para que a bateria entrasse no recuo, deixando a posição inicial que apresentava no desfile. O momento era crítico, porque se o grupo da harmonia e o mestre de bateria não estivessem muito bem sintonizados, vários quesitos do desfile poderiam receber avaliação insatisfatória, perdendo centésimos de pontos que poderiam ser importantes na hora da apuração. Os quesitos que poderiam receber má avaliação eram: bateria, porque algum ritmista poderia atrapalhar-se caso houvesse problema no recuo, saindo do compasso; harmonia, porque as pessoas poderiam, deixar de cantar preocupadas com um recuo desajeitado ou cantar fora do tom ou do ritmo, devido ao descompasso, fato conhecido no mundo do carnaval como "atravessar" o samba. A bateria e a comissão de frente, segundo o regulamento da Liga, não teriam obrigação de cantar o samba, mas o restante da escola deveria cantar. Outro quesito que poderia ter avaliação prejudicada seria a evolução, pois poderiam ser formados os "buracos" quando as alas distanciavam-se umas das outras. Além disso poderia ocorrer a perda do ritmo do deslocamento, resultando em correrias ou redução de velocidade em alguns momentos do desfile.

Percebeu-se que a identidade dos ritmistas e dos harmonias é transformada no no dia do desfile, quando a atuação deles leva à exposição das culturas negras presentes nas escolas, ao sentimento de pertencer a algo maior e ao engajamento. Mesmo com o branqueamento das escolas de samba, depois da oficialização dos desfiles carnavalescos em São Paulo, as agremiações não foram apartadas de suas origens africanas.

\subsection{Análise dos questionários}

Os questionários ${ }^{23}$ foram preenchidos pelos integrantes das escolas de samba, no período de junho a agosto de 2011, no início dos preparatórios para o desfile carnavalesco de

\footnotetext{
${ }^{23}$ Os questionários utilizados nestas pesquisa estão disponível na seção Anexos.
} 
2012. Ele era composto por 11 perguntas. Após as modificações ocorridas nas propostas da presente pesquisa, apenas quatro foram consideradas:

- Por que veio para a escola de samba?

- Qual sua idade?

- Qual função exerce na escola de samba?

- Quanto tempo na escola de samba?

As respostas para as quatro questões indicadas foram dadas de forma direta e não por múltipla escolha.

Os questionários respondidos foram divididos segundo tópicos, como sugere Bardin (1977), no uso da Análise de Conteúdo. Nesta dissertação, a análise dos conceitos foi quantitativa, os resultados foram disponibilizados em gráficos, facilitando a visualização.

$\mathrm{Na}$ análise qualitativa, as respostas foram agrupadas e os conceitos estudados, aplicados à análise. Ao todo foram preenchidos 159 questionários, destes 116 responderam que participavam da escola de samba "por gostar", com ou sem algum complemento (por exemplo, incluindo a intensidade "muito", ou "de samba") ou algum outro sentimento semelhante como "adorar", "respeitar", que pode ser associado às referências positivas, como um dos entrevistados que respondeu "estar na escola de samba era um estímulo contra uma doença". Além disso, 28 pessoas responderam que a família era o motivo para estarem na agremiação e 6 pessoas não responderam esse item do questionário, como pode ser visto no gráfico a seguir.

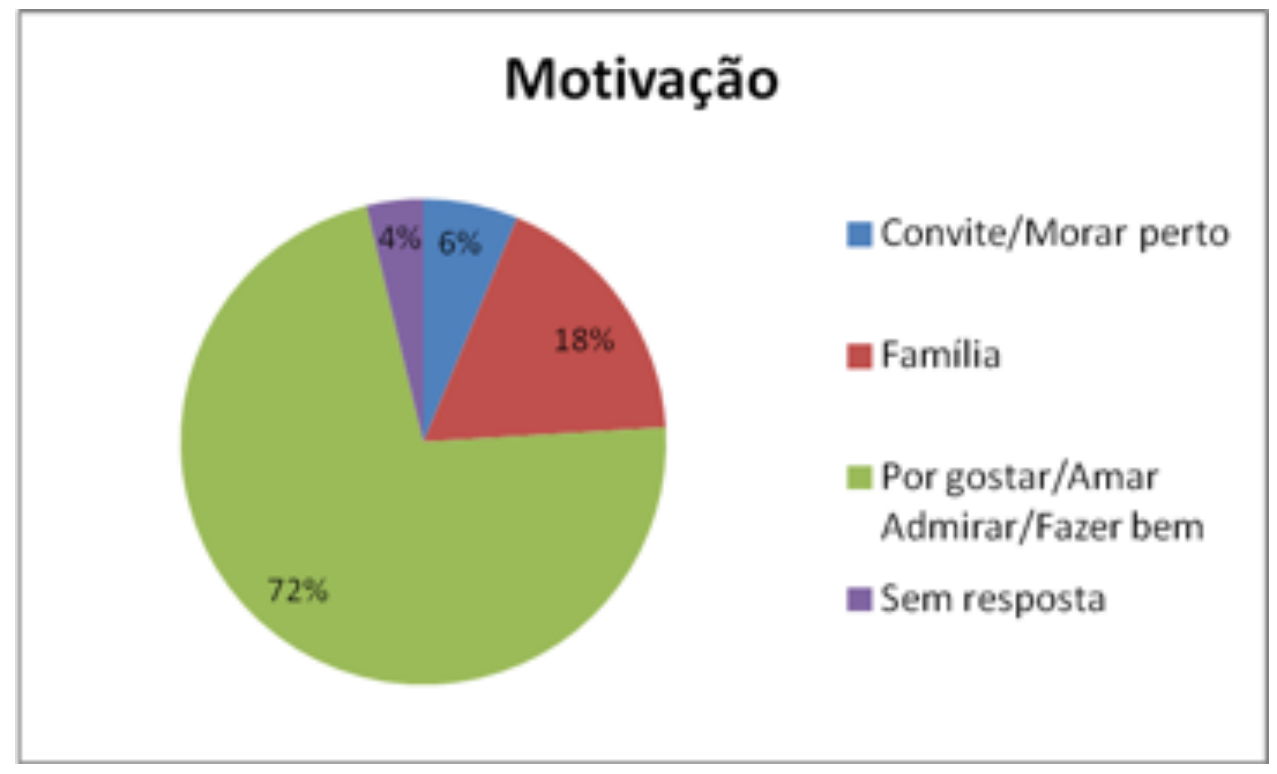

Figura 5: Motivo que levou o entrevistado à escola de samba. 
Com os agrupamentos formados, é possível observar que os três fundamentos descritos por Honneth (2003) estão presentes nas respostas: reconhecimento no meio familiar, no espaço jurídico e no espaço subjetivo do autorreconhecimento.

O grupo que representa o primeiro tipo de reconhecimento foi identificado nas respostas a partir da referência "família". Nestas repostas, que totalizam 28, os pesquisados disseram que estavam na agremiação por herança familiar.

O segundo grupo separado nas respostas teve o tópico "convite" como identificador e apresentou o menor resultado, com 10 respostas claras sobre a forma como a pessoa teve contato com a escola de samba. Ao aceitar o convite para participar de uma agremiação carnavalesca, o entrevistado reconheceu a escola de samba juridicamente, de acordo com o segundo modelo descrito por Honneth (2003). Mesmo que o convite tenha sido feito de maneira não formal, a existência de um evento num lugar predeterminado, demonstra que a festa, ensaio, apresentação foi realizado em um espaço físico reconhecido legalmente, com um endereço que o localizava na cidade. Apesar dos entrevistados não citarem nas respostas as datas em que receberam os convites, inferiu-se que as escolas de samba tinham alguma forma de registro legal junto ao poder público, quando os convites aconteceram - fosse o registro realizado na primeira entidade que congraçou as agremiações carnavalescas da capital (depois de 1967), fossem os registros feitos nas delegacias de polícia, entre o início e a metade do século XX, ou pelas reportagens jornalísticas.

A terceira forma de reconhecimento sugerida por Honneth (2003) e complementada por Fraser (2006) trata do autorreconhecimento do indivíduo no meio social de convivência. Entre os questionários preenchidos, 114 apontaram que tinham algum sentimento positivo em relação à agremiação carnavalesca, como: "por gostar”, "por amar”, “porque é minha escola de coração", "porque me faz bem" etc. São respostas que sugerem que o pesquisado reconheceu-se como parte da escola de samba: o pesquisado legitimou a agremiação e viu-se legitimado por ela.

Este é o tipo mais difícil de reconhecimento, porque o sujeito tem que reconhecer que existe uma instituição e que ele faz parte dela. O pesquisado reconheceu a instituição como algo bom, uma vez que respondeu que gostava, amava ou usou expressões similares para demonstrar o bem-estar de participar da agremiação.

Em todos os casos, porém, foi possível observar que ritmistas ou harmonias reconheceram-se e identificaram-se com a função e com a agremiação as quais faziam parte 


\subsection{A análise das entrevistas}

Caria (2002) e Geertz (2011) indicam a entrevista como uma das possibilidades de obtenção de informações sobre o objeto estudado. Por meio dela, o pesquisador dispõe-se a ouvir o outro, de acordo com a visão e o conhecimento próprio. A experiência do outro, carregada de conceitos, preconceitos, lógicas e raciocínios, pode permitir o aprofundamento e particularização da pesquisa. Nesse estudo, optou-se pela entrevista para a obtenção de dados sobre o tema pesquisado. Sendo o entrevistado um praticante do que se pesquisa, a pesquisa aproximou-se da realidade observada.

\subsubsection{Situando as entrevistas e os entrevistados}

As entrevistas permitiram a verificação da experiência individualizada das pessoas escolhidas. Entre as cinco pessoas entrevistadas, três eram da escola de samba Vai-Vai, uma entrevistada pertencia à escola Rosas de Ouro e a última era da Pérola Negra; havia apenas uma mulher; apenas um dos entrevistados pertencia à bateria; 3 entrevistados têm mais de 50 anos; um deles é filho de um dos fundadores de uma das escolas de samba e 3 dos entrevistados tiveram a responsabilidade de pensar e organizar todo o desfile de uma escola de samba, ocupando a posição de diretores gerais de harmonia.

Os entrevistados foram escolhidos em virtude do envolvimento com as agremiações a que pertenceram, bem como em função do tempo que participam da agremiação. Nenhum deles tinha menos do que cinco anos de atividades desenvolvidas. Eles também foram escolhidos de acordo com a observação não participante da pesquisadora, num período anterior à sistematização desta pesquisa, devido à emoção que os entrevistados demonstraram.

As entrevistas seguiram um roteiro semiestruturado, mas foi permitido e incentivado que os entrevistados explicitassem sua subjetividade à entrevista. A entrevista mais longa durou quase três horas e a menor cerca de 1 hora. Os locais de realização da entrevista foram escolhidos pelos entrevistados: três deles escolheram o espaço físico da escola de samba e dois deles convidaram a pesquisadora para entrevistá-los em suas casas. Entre os entrevistados, quatro eram afrodescendentes; um deles era aposentado, um era gerente de vendas, um era funcionário público, um era educador físico e outro era cartorário. 


\subsubsection{Como foram analisadas as entrevistas}

A Análise de Conteúdo foi utilizada na análise das entrevistas, assim como nos questionários. Nos questionários, a análise focou-se nos aspectos quantitativos das respostas e na compreensão das entrevistas; os aspectos qualitativo focaram-se na observação conforme indicado por Bardin (1977), com o agrupamento das respostas dos entrevistados por meio dos índices. O primeiro índice utilizado foi a família em que nasceu ou aquela a qual se integrou e ajudou o entrevistado a chegar à escola de samba. O segundo índice a ser usado para agrupar as respostas dos entrevistados foi a citação do bairro em que a escola de samba se situava ou de qual local a agremiação veio. A citação do nome da escola de samba pode entrar neste índice, uma vez os entrevistados e os componentes citam o bairro como referência à agremiação. O terceiro índice agrupou as explicações a respeito das atividades desenvolvidas nas escolas, fossem elas comuns ou insanas, relatadas pelos entrevistados durante a entrevista.

\subsubsection{Analisando as falas}

A transcrição de cada uma das cinco entrevistas foi divida seguindo os índices estabelecidos a seguir:

- entes da família ou pessoas de relação de amizade (pai, mãe, tio, irmã, amigo);

- bairro ou apelido do bairro (exemplo: Bela Vista, conhecida como Bexiga), nome da escola de samba ou apelido (por exemplo Rosas de Ouro, também conhecida como Roseira);

- atividades, funções e ações inusitadas que os entrevistados fizeram pela escola de samba.

Em todas as entrevistas, os três índices foram verificados.

A primeira análise foi feita tendo a família como índice. Com base no reconhecimento por meio da família, o ente foi acolhido no seio familiar assim que nasceu ou assim que foi apresentado como participante daquele grupo familiar (HONNETH, 2003).

Observando-se as respostas dadas pelos entrevistados, a introdução nas escolas de samba deu-se pelo primeiro índice. Em duas das cinco entrevistas, os responsáveis por introduzir a componente na escola de samba foram os familiares. Nos demais, foram amigos.

Tanto os familiares como os amigos, foram entendidos não apenas como meros facilitadores para os entrevistados, mas também, assemelhando-se à função exercida pela família, como protetores dos novos componentes na chegada a um ambiente, até então, desconhecido. A única entrevistada relatou: “Ah! Eu tinha uns 14 ou 15 anos, faz bastante 
tempo. Eu ia e ficava do lado da bateria, porque se tivesse alguma confusão, meu amigo me mandava ir para lá (Daniella Alves Maurício, 23.05.2011)”.

Outro entrevistado disse ter desfilado na escola de samba Camisa Verde e Branco porque o tio era um componente de destaque da escola e pôde levá-lo. A Camisa Verde e Branco introduziu o entrevistado no mundo das escolas de samba paulistanas, apesar da modificação da agremiação após 25 anos de dedicação dedicou-se por mais de 25 anos não ser a mesma agremiação: "porque no Camisa só saí esse ano de cuíca com meu tio porque meu tio já era da escola, já era da casa (Fábio Casitas, 4 de junho de 2013)”.

Um entrevistado relatou que a família fundou a agremiação e ele foi levado pelo pai e, seguindo a mesma tradição, levou os filhos, a filha e a neta. Outro entrevistado relatou que os amigos o levaram e que ele levou os filhos, menos um, que é roqueiro, para a escola de samba. O outro disse que foi levado para uma escola de samba (diferente daquela que ele está atualmente) pelos amigos, onde conheceu a mulher. Mas, ao conhecer sua agremiação mãe, ele foi contagiado pela empolgação, fazendo com que a mulher e a sogra o seguissem.

O índice família/amigos não se restringiu à questão da introdução do componente na agremiação e no encaminhamento de entes próximos para a escola de samba. Esse índice também apresentou dados sobre o grau de envolvimento do entrevistado com a escola de samba. A entrevistada relatou: "Sim, lá é minha casa. Aqui é minha casa que eu venho e durmo. Lá é onde eu brigo, eu sorrio, eu me emociono, eu me energizo".

Um dos homens disse que em breve ele levaria uma cama para a escola de samba, numa referência clara à escola de samba como casa ou lar, lugar de acolhimento, de repouso, de confiança. Ao mesmo tempo que integrou e socializou o novo ente, a agremiação carnavalesca recebeu os familiares dos entrevistados, colocando-se na vida deles como estrutura e suporte para seus membros, oferecendo novos locais de reconhecimento e tornando-se mantenedora destes sítios, mesmo com a possibilidade do componente visitar outras escolas de samba, a agremiação-mãe era tida como local de retorno certo.

As escolas de samba paulistanas, assim como as do restante do país, originaram-se da cultura negra. A família negra brasileira, seguindo os passos da família africana, não é uma família nuclear formada por pai-mãe-filhos, mas sim, uma família extensa que além dos componentes citados, aceita e acolhe novos membros e novos entes. Slenes (2011) diz que a principal relação que faz com que a família negra assuma características de uma família extensa é a de compadrio. 
Slenes (2011) indica que neste tipo de relação, uma família apadrinha um ente de outra família e estabelece-se uma ligação quase consanguínea. Desta forma, o ente apadrinhado ganha, na casa dos padrinhos, direitos, cuidados, carinhos e deveres semelhantes aos de um sobrinho ou em casos de ligação mais intensa, de um fillho. O apadrinhamento dá-se pelo batismo, um dos sacramentos da igreja católica. Este batismo cria um vínculo sacro entre padrinhos e afilhados.

$\mathrm{Na}$ relação do componente com a agremiação carnavalesca, também houve um símbolo que assumiu um caráter sacro, o pavilhão, como cita Adriana Gomes em entrevista exibida em dezembro de $2012^{24}$. O símbolo maior da escola de samba, o pavilhão, é entendido e sentido pelo novo ente como um objeto de proteção e de representação. Enquanto numa família extensa as relações consanguíneas e sacramentais vêm dos entes mais velhos, em uma escola de samba esta função é ocupada pela pavilhão.

Poder-se-ia dizer que quando o componente aceita uma agremiação como escola de samba-mãe, mesmo quando o fizeram por tradição familiar, o novo componente sente-se apadrinhado pela escola. Na condição de afilhado, que muitas vezes tem os deveres e os direitos de filho, o componente transforma a escola de samba em parte de sua família e de sua vida.

O segundo índice escolhido para analisar as entrevistas diz respeito ao nome e a estrutura física: o bairro e a escola de samba. Honneth (2003) propõe em seus estudos que a segunda forma de reconhecimento é o jurídico. Neste índice de análise, os dois temas escolhidos, o bairro e o nome da agremiação, trouxeram o caráter jurídico da escola de samba para seus seguidores.

A primeira forma de reconhecimento jurídico é ter um nome, no caso de uma criança, por meio do registro civil, no caso de uma entidade, de acordo com a ata de fundação, sempre registrados em cartório.

Conforme proposto no Capítulo 2, apesar de as escolas de samba paulistas existirem desde o início do século XX na cidade, elas foram legitimadas e reconhecidas pela sociedade no final dos anos de 1960. O catalisador deste processo de reconhecimento das escolas de

\footnotetext{
${ }^{24}$ Disponível em: <http://g1.globo.com/videos/sao-paulo/sptv1edicao/t/edicoes/v/pavilhao-e-simbolo-maior-das-escolas-de-samba/2292168/\&h=uaqe $7 \mathrm{pn}$ sp\&s=1/->. Acesso em: 2 nov. 2013.
} 
samba foi a escolha de um homem branco como presidente da primeira entidade a congraçar as entidades carnavalescas da época.

Moraes Sarmento era um profundo conhecedor e defensor da cultura popular, mas não estava diretamente envolvido com os festejos carnavalescos da capital paulista. Mesmo assim, foi o escolhido e, por ter bom relacionamento com o poder público e com a imprensa, ajudou na fundação da primeira entidade das agremiações carnavalescas da cidade. Como a entidade foi toda pensada e desenvolvida por componentes das escolas de samba, como cita Fernando Penteado, todos ficaram satisfeitos com o resultado, além de terem sido reconhecidos e aceitos pela sociedade.

Seguindo essa lógica, percebeu-se que os entrevistados reconheceram-se civilmente na agremiação mãe. O gerente de venda disse: “eu tenho, graças a Deus, consegui o nome no samba, ah o Buiu da Vai-Vai. As pessoas não sabem meu nome, mas as pessoas sabem quem é o Buiu da Vai-Vai”. O entrevistado disse que no microcosmo formado pelas escolas de samba, ele adquiriu um nome em função da escola de samba da qual faz parte. Tal observação também foi feita quando os entrevistados citaram componentes de outras escolas. Para identificá-los, após o primeiro nome, o componente era indicado com a agremiação a qual fazia parte.

Para os entrevistados, a agremiação carnavalesca tornou-se um sobrenome, no universo das escolas de samba paulistanas. O significado desse sobrenome é ampliado quando se leva em consideração que o movimento teve origem em famílias negras, que sofreram muitas negações ao longo do período escravocrata, inclusive do próprio nome, trocado por um nome cristão, no ato do batismo. Por terem sido tratados como objetos, não tendo, por isso, o direito a identificação legal, como o nome e o sobrenome (FERNANDES, 2008), ter o sobrenome da escola de samba representa o reconhecimento, no ambiente das escolas de samba.

Para alguns, o reconhecimento extrapolou o espaço das agremiações carnavalescas: um dos entrevistados citou que ao ser anunciado em eventos políticos como integrante de uma escola de samba, foi recepcionado de forma diferenciada. Um exemplo que extrapola o ambiente das escolas de samba, é o de Edimar Tobias. Ele não faz parte do grupo de entrevistados desta pesquisa, mas é um excelente exemplo. Em 1980, ele era um dos puxadores de sambas enredo (cantor) mais conhecidos de São Paulo. Porém, até hoje, ele não é conhecido ou reconhecido por este nome. Quem procurar por Edmar Tobias, nas ruas da 
Bela Vista, onde mora, não irá encontrá-lo. Se a perguntar pelo Tobias da Vai-Vai, a maioria irá dizer que o conhece e alguns poderão até indicar onde ele mora, no bairro.

O terceiro índice para análise das entrevistas baseou-se nas atividades desenvolvidas pelos componentes, agrupando-as no item que Honneth (2003) e Fraser (2003) trataram como autorreconhecimento. Os autores divergem sobre os motivos que levam ao autorreconhecimento, mas concordaram ser este o terceiro modelo de reconhecimento possível e o mais difícil, uma vez que a ação do reconhecimento neste caso é realizada pela própria pessoa, por meio da subjetividade.

A partir das atividades desenvolvidas indicadas pelos entrevistados, tanto as esperadas quanto as inesperadas, foi possível observar a relação criada entre o componente e a agremiação a qual se incorporou.

Os entrevistados citam que deixaram, muitas vezes, atividades familiares para comparecer a eventos em que a agremiação iria apresentar-se.

Um deles disse que:

Momentos que você podia estar um pouco mais com sua família, você não pensava muito, você tava aqui (na Vai-Vai). Precisa ir viajar... Mas quantos Réveillons eu fiz, e minha família tava em casa? (Edson Francisco Paulino, 5 de junho de 2012).

Outro entrevistado disse que se deslocava para a agremiação todos os dias, durante o período próximo do Carnaval, mesmo morando na zona sul da capital, no extremo oposto do local da escola de samba. A entrevistada disse que sempre pede as férias para o mês anterior ao desfile carnavalesco para poder ajudar no barracão da escola. Outro entrevistado disse que participou do setor de harmonia da escola (mesmo não exercendo essa função na escola), para ajudar a melhorar esse quesito. Outro entrevistado disse ter passado por todos os setores da escola de samba, porque para ser um bom sambista: "você era obrigada a saber sambar, você era obrigado a saber cantar, você era obrigado a saber tocar, senão você não era sambista”. A partir dos relatos dos entrevistados, observou-se que eles comprometeram-se e engajaram-se na causa da escola de samba.

Fernando Penteado, um dos entrevistados, disse que o "o harmonia é um guerrilheiro, ele luta pela causa e não pelo soldo", demonstrando o total engajamento e comprometimento dos componentes das escolas de samba.

Mas, por que isso aconteceria? Por que engajar-se e comprometer-se com algo lúdico, que não traria remuneração? 
Segundo as observações realizadas, os entrevistados reconhecem-se nas agremiações. Ao reconhecerem-se, tomaram para si a responsabilidade de executar as funções a que se propuseram, além de outras, visando a melhor execução do desfile.

Ao fazer parte de uma família, ter um sobrenome, mesmo que no mundo do samba, o componente sente-se acolhido e tomado pelo sentimento de pertencimento, gerado pela participação de uma agremiação. O componente sente-se parte de um grupo responsável por apresentar um grande espetáculo e desdobra-se para fazê-lo.

Um dos entrevistados disse que a escola de samba busca o sucesso, fazendo com que os componentes realizassem ações além das esperadas ou das designadas. $\mathrm{O}$ entrevistado disse ainda que eles acreditam que faziam a diferença.

Nenhum dos entrevistados disse agir para ganhar a disputa, mas sim para empolgar e apresentar o melhor espetáculo para o público. A vitória seria uma consequência.

Depois de meses de ensaios, de acompanhamento da produção das alegorias no barracão, de fantasias em ateliês, no dia dos desfiles os entrevistados dizem que ficam tão focados em suas funções que, muitas vezes, mal podem ver os desfiles de que participaram. Um deles, por exemplo, comentou que se lembrava de alguns momentos do desfile. O outro disse que ficava tão atento aos ritmistas que comandava e ao mestre que seguia que não conseguia olhar para a arquibancada. O terceiro disse que mesmo com a pressão alterada, em má condição de saúde, participou do desfile. A entrevistada disse que não aproveitou nenhum dos desfiles de que fez parte e o quinto entrevistado disse que ficava atento o tempo todo ao que acontecia durante os desfiles, porque tinha que tomar decisões rápidas.

$\mathrm{O}$ autorreconhecimento do entrevistado junto à agremiação-mãe deu-se por meio do comprometimento, do engajamento e gerou um sentimento de pertencimento que fez com que o componente pensasse, agisse e reagisse tendo a agremiação como ponto principal de uma parte de sua vida. Parte de suas vidas, porque nenhum deles vivia de proventos recebidos da escola de samba, todos trabalhavam, como fizeram questão de frisar, além de terem suas famílias, empregos e demais compromissos.

As falas também demonstraram que não só o racional pronunciou-se durante o desfile. A sensação que muitos tentaram descrever era tão intensa que se assemelhava a um transe: a consciência sofreria alguma alteração, suspendendo possíveis dores e sentimentos ruins, como a tristeza, no período em que a escola de samba fazia sua apresentação para a arquibancada e para os jurados. 


\section{Considerações Finais}

A partir do início da atuação da atividade profissional que nos colocou diretamente em contato com as escolas de samba até o final do trabalho de campo e da análise dos resultados obtidos, muitos preconceitos, pessoais e externos foram verificados. Ao perceber os preconceitos plantados e perpetuados em nós, pode-se constatar também o preconceito que envolveu e envolve as escolas de samba, em geral, e as paulistanas, em especial, que foram o foco desta pesquisa.

O contato direto com o objeto de estudo, por meio da atividade profissional ou pela pesquisa realizada, permitiu-nos desmistificar visões estereotipadas em relação às escolas de samba, de modo a facilitar o entendimento das relações estabelecidas entre a sociedade e essas agremiações, além dos elementos preconceituosos do senso comum, que permeiam esses espaços que têm origem afrodescendente. Segundo um relato de João Roberto Dias:

o carnavalesco e o arquiteto e você acabo sendo o engenheiro que punha a coisa em prática. Então ele joga ideia que você tem que trabalhar com aquela ideia com 3000 3000 e poucos componentes e fazer daquilo um espetáculo para o público de maneira, digamos assim, correta coerente, sem percalços, né?! Então, o trabalho da harmonia eu sempre digo para os meninos... eu costumo dizer para as meninas que querem: é muito legal! Fala assim: harmonia bota roupa, dar pinta, a mulherada cai em cima, né?! Mas ser harmonia não é fácil não, o cara que leva a sério... tem que se dedicar muito, tem se dedicar muito (João Roberto Dias, 02 de junho de 2011).

$\mathrm{Na}$ luta de forças e de poder existente na sociedade, as escolas de samba são um locus de manutenção da cultura proveniente dos vários povos africanos que vieram para o Brasil, durante mais de 300 anos de escravidão. Frente à política de branqueamento imposta pelos governantes brasileiros, desde o final do século XIX, que acreditava que o atraso econômico, social e cultural do país vinha da presença dos povos de origem africana, ter agremiações que prezam, mantêm e difundem as culturas negras é a possibilidade de criar um espaço de resistência aos preconceitos e aos racismos vivenciados pelos afrodescendentes. Com diz Fernando Penteado:

Porque a gente misturou, virou uma baita mistura, né? Então a gente não tem essa referência. E a gente aqui no Vai-vai, nós seguramos isso, não somos nada contra ninguém, somos uma escola negra mas num bairro italiano, entendeu? Onde o negro e o branco vivem em perfeita harmonia, graças a Deus. Na nossa diretoria tem branco, também, mas, assim, eu digo assim, o comando é nosso (Fernando Penteado, 30 de maio de 2011). 
O ambiente que envolve as escolas de samba paulistanas, mesmo que no início do século XXI, ainda carrega muito preconceito contra os descendentes de africanos escravizados que foram trazidos ao Brasil e também contra as manifestações artísticas, culturais, gastronômicas e sociais ligadas a esse componente da sociedade brasileira.

O racismo e os preconceitos puderam ser observados, desde o período escravista até os dias atuais. Se tivessem reduzido ou mesmo desaparecido, durante o século $\mathrm{XX}$, não teria sido necessária a instituição de um sistema de cotas para que as diferenças sociais, causadas pelo racismo e o tratamento desigual recebido pelos afrodescendentes fosse reduzida com a proposição de oportunidades igualitárias, presentes na sociedade brasileira do século XXI. O racismo permanece e pode ser visto: somente uma década depois que a lei das cotas foi implantada, a redução das diferenças começa a ser divulgada.

Mesmo na posição desfavorável em que foram colocadas, as populações negras que se deslocaram para a capital paulista vindas do interior do Estado, conseguiram sobreviver apesar das adversidades causadas, principalmente, pela falta de empregos e estudos.

O fim da escravidão não alterou substancialmente as condições de vida dos afrodescendentes, pois tiveram que viver em lugares afastados, sem infraestrutura. O dinheiro que recebiam em atividades que os demais se recusavam a fazer era pouco e nem sempre constante. Isso indicou que a igualdade social e política que o fim da escravidão poderia trazer para os afrodescendentes reverteu-se em abandono das populações negras, devido ao racismo dos governantes.

As adversidades eram muitas, mas mesmo com todas elas, as famílias reuniam-se e, em vez de serem ouvidas lamentações, ouviam-se músicas. Eram as comemorações pelas vitórias diárias, na batalha pela vida.

Não seria incoerente comemorar mesmo tendo tantas adversidades? Sim, seria. Se o povo que vivenciou essa penúria não fosse de origem africana. Dentre os costumes africanos, entoar cânticos, dançar e comer faziam parte de liturgias religiosas e do dia a dia dos povos originários da população afrodescendente brasileira. A cultura que acompanhou e acompanha ainda hoje os povos de origem africana foi ressaltada nesta pesquisa porque o cenário da pesquisa, as escolas de samba, originou-se desse grupo.

Os afrodescendentes paulistanos mantiveram estes costumes antigos, preservando a memória de seus ancestrais. A cultura hegemônica não foi desconsiderada, uma vez que era 
vista e vivenciada diariamente. Mas a cultura ancestral, vinda da África e mantida nas senzalas das fazendas brasileiras, seguiu sendo vivenciada, relembrada e utilizada.

Os primeiros blocos e grupos carnavalescos da capital paulistana nasceram de alguns desses grupos familiares. A apresentação desses grupos demonstrou que o costume e a cultura afro-brasileira deixaram os espaços privados das precárias residências e mostraram-se no espaço público das ruas.

A ida à rua, a princípio considerada lúdica e efêmera, manteve-se por anos, incomodando autoridades e a elite branca, mesmo sofrendo comas imposições do poder policial para que a agremiação pudesse tomar as ruas.

O cenário do início do século XX repetiu-se por todo o século uma vez que os componentes das escolas de samba e as próprias agremiações eram ignorados e, quando vistos, era pelo poder policial, como diz Fernando Penteado, da Vai-Vai:

a gente esperava, porque tinha que tirar os carros correndo dali (avenida Tiradentes) que vinha o Tenente Nakahara, que hoje é Coronel, ele vinha com uma motosserra serrando os carros, as alegorias no meio. A gente tinha que levar de volta pra regional da Sé, que é na Avenida do Estado (Fernando Penteado, 30 de maio de 2011).

A opressão sofrida pelo povo negro remonta ao período escravista, quando os africanos e seus descendentes foram ignorados em suas necessidades e receberam tratamentos semelhantes àqueles dispensados a animais, por serem considerados mercadorias.

O mesmo povo que ficara à margem da sociedade nos últimos quinhentos anos, conseguiu manter e preservar alguns aspectos de sua cultura originária. A manutenção da memória ancestral permitiu a este grupo populacional criar pontos de resistência e de afirmação frente à cultura hegemônica que lhes castigou fisicamente no período escravista e até hoje, castiga sua autoestima, sua honra, seu orgulho.

Um destes pontos de resistência foi a escola de samba que - mesmo em uma cidade cosmopolita e multicultural como São Paulo, e de sofrer a influência da cultura hegemônica foi ciosa da origem negra que teve. Fernando Penteado comenta esta manutenção:

eu aprendi desde cedo o que é o samba. os bastidores dos samba. desde cedo eu os acompanhava ali. Eu fui fluindo dentro da escola [...] do cordão Vai-Vai (Fernando Penteado, 30 de maio de 2012).

Mesmo que no início do século XXI, muitas escolas não tenham dirigentes afrodescendentes, o que pulsa no rufar da bateria, é uma herança africana. 
Mesmo tendo origem afrodescendente, os desfiles carnavalescos eram alvo de preconceitos vindos, muitas vezes, de outros afrodescendentes devido ao racismo imposto pela sociedade e refletido nos membros das populações negras, com diz Daniella Alves Maurício:

Minha mãe sempre gostou e até desfilou duas vezes. Minha vó também gostava de ver pela televisão. Mas, minha vó era do tempo em que escola de samba não era considerado um bom lugar. Minha mãe desfilou escondido, mas minha tia contou e minha vó deu uma bronca na minha mãe (Daniella Alves Maurício, 23 de maio de 2011).

De acordo com a fala dos componentes da escola, por meio do questionário ou das entrevistas foi possível perceber que a escola de samba, nos dias atuais, depois da família constituída, foi uma das formas de propagação dos valores, da cultura e os costumes afrodescendentes. Todos estes elementos foram responsáveis por uma das formas mais autênticas de resistência à cultura hegemônica por parte da população de ascendência africana. Em um dos exemplos dos costumes constantes da cultura negra podemos citar o de se doar para a tribo, para o grupo, para a comunidade, com o diz Daniella Alves Maurício:

Sim é. Eu não recebo, eu doo meu tempo, eu desempenho funções. Sim é um trabalho voluntário que faço em prol da escola de samba e, também, em prol de mim mesma que me sinto feliz e orgulhosa do trabalho que realizo. Fora que a escola, toda a escola de samba, tem que realizar trabalho social com a comunidade que depois, devolver para a escola. É um círculo: eu sou voluntária fazendo o espetáculo; a escola ajuda a comunidade com ações solidárias como consultas médicas, distribuição de leite e oficinas de capacitação; e a comunidade devolve para a escola ajudando na preparação do carnaval (Daniella Alves Maurício, 23 de maio de 2011).

A questão da cor pele de quem participa da agremiação carnavalesca foi deixando de ser um elemento importante para a inclusão nas agremiações, dando espaço para o fortalecimento de sentimentos e ideias que os mantiveram unidos, comprometidos e engajados nas escolas de samba.

A cor da pele do componente, principalmente dos citados anteriormente, não se fez tão importante, mas sim o sentimento e o pensamento que os mantiveram ligados, comprometidos e engajados às escolas de samba.

Eu costumo dizer assim, goste ou não goste, nós somos regidos pela cultura africana. Goste ou não goste, nós somos regidos pelos nossos orixás, entendeu? Então ele acaba incorporando isso. Ele pode ser um japonês, mas ele acaba incorporando isso (Fernando Penteado, 30 de maio de 2011). 
A identificação e o reconhecimento que as escolas de samba levaram a seus componentes faz com que eles compreendam a importância de ser o que são, na escola de samba e na vida, e valorizem suas origens. Estar na escola de samba foi como ser conhecido e reconhecido, apesar de todos os fatores contrários, como por exemplo, ainda estar à margem da sociedade. Fazer parte de um grupo carnavalesco foi equivalente à valorização na sociedade paulistana.

eu tenho, graças a Deus, consegui o nome no samba, ah o Buiu da Vai-Vai. As pessoas não sabem meu nome, mas as pessoas sabem quem é o Buiu da Vai-Vai (Edson Francisco Paulino, 05 de junho de 2012).

O vínculo estabelecido junto à escola de samba e ao modo de ser do afrodescendente presente nestas agremiações, puderam fazer com que os componentes adquirissem uma nova forma de olhar o mundo, elevando a autoestima do componente por meio da fraternidade vivenciada, da participação exercida, do comprometimento demonstrado e do engajamento absorvido. Todos estes princípios levaram o componente a obter um bem para si mesmo. Ao aplica-los diretamente na escola de samba, ajudaram a desenvolver um bom desfile.

E o trabalho que a gente fala que é de coração, é de administração é da Harmonia, porque o Presidente corre atrás dos recursos pra montar estrutura de barracão, de fantasia, o mestre de bateria ensaia pra que dê um melhor ritmo pra que a escola possa fazer um trabalho, mas a convivência com 4.500, 5 mil, 6 mil pessoas, de componentes que vêm cada um de um lado, cada um de uma maneira, cada um pensando de um jeito é o mais difícil, porque o harmonia... Se ele não participar com o carnavalesco, pra conhecer o projeto do carnavalesco, se ele não tiver um bom entrosamento com o mestre de bateria pra que a bateria dê o que ele precisa pra fazer o carnaval, ele não consegue fazer um bom trabalho. E se ele não tiver uma equipe que trabalhe com ele e enxergue da mesma maneira que ele enxerga, você não faz uma Harmonia (Edson Francisco Paulo, 05 de junho de 2012).

Retornando à nossa primeira questão, que conduziu essa dissertação: por que as pessoas atuaram mesmo não sendo remunerada?

A resposta dada, após a leitura dos teóricos, a observação livre, a análise dos questionários e das entrevistas foi que a remuneração obrigaria as pessoas a executarem as atividades, enquanto que o engajamento, criado por um processo de identificação, não traria nenhuma obrigatoriedade de atuação. Como diz a entrevistada:

Sim, lá é minha casa. Aqui é minha casa que eu venho e durmo. Lá é onde eu brigo, eu sorrio, eu me emociono, eu me energizo. É um amor incondicional que eu tenho pelo Vai-Vai. Agora que está um pouco mais calmo eu vou apenas uma vez por semana. Mas, conforme vai chegando perto, eu tenho mais e mais compromissos em dias diferentes da semana. E eu sou meio sem medida ou eu sou ou eu não sou. Então, eu acabo me dando muito mais do que poderia, mas não consigo ser de outro jeito (Daniela Alves Maurício, 23 de maio de 2012). 
A remuneração recebida por qualquer atividade executada é necessária à manutenção da vida, da sobrevivência, dos cidadãos estudados e para os demais. Ela permite a perpetuação dos seres humanos, que compram os produtos para seu sustento, diferentemente dos animais selvagens. Porém, a remuneração equiparou as necessidades do ser humano a dos animais; por meio dela, o homem sobreviveu, ao manter funções básicas, como comer, morar, vestir: necessidades semelhantes às observadas dentro os animais irracionais.

O engajamento, de acordo com nossa observação, pode trazer transformações aos sujeitos conscientes de suas subjetividades, de suas potencialidades e de suas emoções. Esta transformação e outras transformações podem ter sido obtidas por outros meios, que não foram focadas neste estudo. Porém, o engajamento fez com que os pessoas entrevistadas deixassem de sobreviver e passassem a viver, uma vez que o racional e o sentimental, foram externados possibilitando que as ações propostas fossem realizadas. A fala de Fábio Augusto Casitas demonstra a total entrega do componente à escola:

dependendo do breque assim, se você errar, dá pra você fazer um repique com o surdo pra que o jurado não perceba, sabe? Por isso que é um instrumento de confiança, e na avenida tem hora que a galera fica muito deslumbrada, sabe? Então muitos erros na bateria acontecem por causa disso, porque eles ficam deslumbrados. Então o cara que toca surdo não pode ficar deslumbrado, eu não consigo ver nada do meu desfile quando eu tô tocando, quando eu desfile. Eu não consigo ver a escola passando, eu não consigo olhar pra arquibancada, eu sempre concentrado e olhando pro mestre de bateria (Fábio Augusto Casitas, 4 de junho de 2013).

O desenvolvimento destas habilidades levou os entrevistados - e poderia levar todos aqueles que se engajaram a alguma causa, mesmo frente à maratona de trabalho que o desfile carnavalesco gerou - a ter uma vida em comunidade, com mais momentos de satisfação, de alegria e de felicidade.

Tá trabalhando, não vê carnaval. "Você viu a coisa que saiu [...]". Eu não sei, eu nem vi que roupa que ela tava, eu não vi nada dos carros. Você vem tão empolgado, você tá vendo no ali tá abrindo um buraco, você quer arrumar aquilo ali. "Ah, mas no Desfile das Campeãs, você [...]", mentira, eu também não curto o Desfile das Campeãs, porque você ainda tá naquele clima, você tem responsabilidade. Harmonia não acaba responsabilidade (Edson Francisco Paulino, 5 de junho de 2012).

Estar em uma escola de samba gerou boas sensações e bons sentimentos nos entrevistados e fez com que eles permanecessem ligados a elas, sem a necessidade de serem remunerados, transformando as identidades na relação direta com a sociedade em que convivem e mudando a forma de viver em grupo. Em vez de seguir a corrente comum da 
sociedade capitalista, cuja sobrevivência e a acumulação de bens é uma regra que animaliza os indivíduos, os componentes das escolas de samba, apesar de não terem deixado de trabalhar e receber suas remunerações, participam de suas comunidades, não apenas sobrevivendo, mas também vivendo engajados em uma causa. 


\section{Bibliografia}

ALBUQUERQUE, Wlamyra R. de \& FRAGA FILHO, Walter. Uma história do negro no Brasil. Salvador. Centro de Estudos Afro-Orientais. Brasília: Fundação Cultural Palmares, 2006.

ARAÚJO. Ligia Fernandes. A escola de samba Lavapés: um patrimônio cultural no Glicério. Disponível em: <http://www.usp.br/celacc/ojs/index.php/blacc/article/view/445>. Acesso em: 2 nov. 2013.

AZEVEDO, Clara de Assunção. Fantasias negociadas. Políticas do carnaval paulistano na virada do século XX. Dissertação de Mestrado. Universidade de São Paulo, 2010.

BARDIN, Laurence. Análise de Conteúdo. Lisboa, Edições 70, 1977.

BLASS, Leila Maria da Silva. Desfile na avenida, trabalho na escola de samba: a dupla face do carnaval. São Paulo: Annablume, 2007.

A dimensão pedagógica da Embaixada do Samba. Disponível em: $<$ http:// revistas.pucsp.br/index.php/pontoevirgula/article/viewFile/13899/10223>. Acesso em: 2 nov. 2013.

BRÜGGER, Silvia Maria Jardim. Compadrio e Escravidão: uma análise do apadrinhamento de cativos em São João Del Rei, 1730-1850. Artigo apresentado no XIV Encontro Nacional de Estudos Populacionais, ABEP, realizado em Caxambú-MG, de 20-24 de setembro de 2004.

CARIA, Telmo H. Experiência etnográfica em Ciências Sociais. Porto: Edições Afrontamento, 2002.

CEZAR, Lilian Sagio. Saberes contados, saberes guardados: a polissemia da congada de São Sebastião do Paraíso, Minas Gerais. Disponível em: <www.scielo.br/scielo.php script $=$ sci_arttext\&pid=S0104-71832012000200008\&lng=en\&nrm=iso\&tlng=pt $>$. Acesso em 2 nov. 2013.

CIAMPA, Antonio da Costa. A estória de Severino e a história de Severina. São Paulo: Editora Brasiliense, 1987.

CORRÊA, Felipe. Três hipóteses da teoria do poder em Foucault. In Psicologia Política: Debates e Embates de um campo Interdisciplinar. São Paulo: Edições EACH, 2012.

DAMATTA, Roberto. Carnavais, Malandros e Heróis. Para uma sociologia do dilema brasileiro. Rio de Janeiro: Civilização Brasileira, 1999.

DOMINGUES, Petrônio. Ações Afirmativas para negros no Brasil: o início de uma reparação histórica. Disponível em: <http://www.scielo.br/scielo.php? script=sci_arttext\&pid=S1413-24782005000200013>. Acesso em: 2 nov. 2013. 
FERNANDES, Florestan. A integração do negro na sociedade de classes. São Paulo: Editora Globo, 2008.

FERRARA, Miriam Nicolau. A imprensa negra paulista (1915 - 1963). São Paulo: FFLCH/ USP, 1986.

FERREIRA, Felipe. Livro de Ouro do Carnaval Brasileiro. São Paulo: Ediouro, 2004.

FRASER, Nancy. ¿Redistribuición o reconocimiento?: um debate político-filosófico. Madrid: Ediciones Morata, 2006.

FREIRE, Gilberto. Educação e Mudança. Rio de Janeiro: Paz e Terra, 1979.

GEERTZ, Clifford. A interpretação das Culturas. Rio de Janeiro: LTC, 2011.

GUIMARÃES, Antonio Sergio Alfredo. Preconceito de cor e racismo no Brasil. Disponível em: $<$ www.scielo.br/scielo.php?pid $=$ S0034-77012004000100001\&script $=$ sci_arttext $>$. Acesso em: 2 nov. 2013.

HONNETH, Axel. Luta por reconhecimento: a gramática moral dos conflitos sociais. São Paulo: Editora 34, 2003.

JESUS, Edson Roberto. Herança de Resistência. Primórdios do samba na cidade de São Paulo - do final do século XIX ao início do século XX. Dissertação de Mestrado. Pontifícia Universidade de São Paulo, 2004.

LODY, Raul Giovanni. Afoxé. Coleção Cadernos de Folclore do Ministério da educação e Cultura. Rio de Janeiro: Editora Lidador, 1976.

LOPES, Nei. O negro no Rio de Janeiro e sua tradição Musical - Partido-alto, calango, chula e outras cantorias. Rio de Janeiro: Pallas, 1992.

2003.

. Sambeabá: o samba que não se aprende na escola. Rio de Janeiro: Folha Seca,

. Bantos, malês e identidade negra. Rio de Janeiro: Autêntica, 2006.

MENDES, José Sacchetta Ramos. Desígnios da Lei de Terras: imigração, escravismo e propriedade fundiária no Brasil Império. Disponível em: <www.scielo.br/scielo.php? script=sci_arttext\&pid=S0103-49792009000100011>. Acesso em 2 nov. 2013.

MORAES, Eliane Robert. Um vasto prazer, quieto e profundo. Disponível em: $<$ www.scielo.br/scielo.php?pid=S0103-40142009000100018\&script=sci_arttext $>$. Acesso em: 2 nov. 2013.

MORAES, José Geraldo Vinci de. As sonoridades paulistanas. A música popular na cidade de São Paulo (final do século XIX - início do século XX). Dissertação de Mestrado. Pontifícia Universidade Católica de São Paulo, 1989. 
MOTA, Carlos Guilherme. São Paulo: exercício de memória. Disponível em: $<$ www.scielo.br/scielo.php?pid $=$ S0103-40142003000200020\&script $=$ sci_arttext $>$. Acesso em 2 nov. 2013.

NETTO, Fernando Franco. Propriedade de escravos e relação de compadrio: Castro e Guarapuava na segunda metade do século XIX. Artigo apresentado $5^{\circ}$ Encontro Escravidão e Liberdade no Brasil Meridional, em Porto Alegre de 11 a 13 de maio de 2011.

OLIVEIRA, Dennis de. Culturas de grupos subalternizados: espaço para construção de novas subjetividades políticas. In: Mídia e diversidade Cultural: experiências e reflexões. / Maria Luisa Martins Mendonça (org.). Brasília: Casa das Musas, 2009.

PRAZERES, Priscila Aparecida. Maracatu nação e a busca pela compreensão de seus aspectos religiosos: dos estudos folclóricos culturais à vivência dos jovens integrantes do Arrasta Ilha com o mestre da nação do maracatu Porto Rico. Disponível em: $<$ www3.fe.usp.br/secoes/inst/novo/agenda_eventos/inscricoes/PDF_SWF/11425.pdf $>$. Acesso em: 2 nov. 2013.

PICHON-RIVIÈRE, Enrique. Teoria do Vínculo. São Paulo: Martins Fontes, 2000.

RAMOS, Alberto Guerreiro. Cartilha Brasileira do aprendiz de sociólogo (prefácio a uma sociologia nacional). In: Introdução Crítica à Sociologia Brasileira. Rio de Janeiro: Editorial Andes Limitada, 1957.

RIBEIRO, Fabia Barbosa. Caminho da piedade, caminhos de devoção as irmandades de pretos no Vale do Paraíba Paulista - século XIX. Tese de doutorado. Universidade de São Paulo, 2010.

SANTOS, Roberval de Jesus Leone dos. Modelos de engajamento. Disponível em $<$ www.scielo.br/scielo.php?pid=S0103-40142005000200021\&script=sci_arttext $>$. Acesso em: 2 nov. 2013.

SILVA, Vagner Gonçalves da. Candomblé e Umbanda. Caminhos da devoção brasileira. São Paulo: Selo Negro, 2005.

Intolerância religiosa. Impactos do neopentecostalismo no campo religioso afro-brasileiro. São Paulo: EDUSP, 2007.

SIMSON, Olga R. de Moraes Von. Carnaval em Branco e Negro: carnaval popular paulistano: 1914 - 1988. São Paulo: EDUSP, 2007

SLENES, Robert W. Na senzala uma flor - Esperanças e recordações na formação da família escrava. Campinas: Editora Unicamp, 2011.

SODRÉ, Muniz Sodré. Samba, o dono do corpo. Rio de Janeiro: Muad, 1998. 
A verdade seduzida. Por um conceito de Cultura no Brasil. Rio de Janeiro: DP\&A, 2005.

TURETA, César. PRÁTICAS ORGANIZATIVAS EM ESCOLAS DE SAMBA: o Setor de Harmonia na Produção do Desfile do Vai-Vai. Tese de Doutorado. Fundação Getúlio Vargas, 2011.

ULHÔA, Martha Tupinambá, Inventando moda:a construção da música brasileira. Disponível em: <www.ictus.ufba.br/index.php/ictus/article/view/118>. Acesso em: 2 nov. 2013.

URBANO, Maria Apparecida. Carnaval \& Samba em evolução, na cidade de São Paulo. São Paulo: Plêiade, 2006. 


\section{ANEXOS}

ANEXO A - Notas atribuídas às escolas de samba

\section{CLASSIFICAÇÃO GERAL - GRUPO ESPECIAL-2010}

\begin{tabular}{|l|l|l|l|l|l|l|l|l|l|l|}
\hline Quesitos & Mestre & Aleg. & Samba & Fantasia & Enredo & Bateria & Harm. & Evolução & Comiss. & TOTAL \\
\hline Rosas de Ouro & 30 & 30 & 30 & 30 & 30 & 30 & 30 & 30 & 30 & 270.00 \\
\hline Mocidade Alegre & 30 & 30 & 30 & 30 & 30 & 30 & 30 & 30 & 29.75 & 269.75 \\
\hline Vai-Vai & 30 & 30 & 30 & 29.75 & 30 & 30 & 30 & 29.75 & 29.75 & 269.25 \\
\hline Mancha Verde & 30 & 29 & 30 & 30 & 30 & 30 & 30 & 30 & 30 & 269.00 \\
\hline Gaviões da Fiel & 30 & 30 & 30 & 30 & 29.25 & 30 & 30 & 29.75 & 29.75 & 268.75 \\
\hline U. Vila Maria & 30 & 29.75 & 30 & 30 & 30 & 30 & 30 & 29.5 & 29.5 & 268.75 \\
\hline Império de Casa Verde & 30 & 29.25 & 30 & 29.75 & 29.5 & 30 & 30 & 30 & 30 & 268.50 \\
\hline Acadêmicos do Tucuruvi & 30 & 30 & 30 & 30 & 30 & 30 & 30 & 28.25 & 30 & 268.25 \\
\hline X-9 Paulistana & 30 & 30 & 29.75 & 30 & 30 & 29.5 & 29.75 & 29 & 30 & 268.00 \\
\hline Pérola Negra & 30 & 30 & 30 & 30 & 30 & 29.25 & 29.75 & 29.25 & 29.75 & 268.00 \\
\hline Águia de Ouro & 30 & 29.25 & 29.75 & 29.5 & 29.5 & 29 & 29.25 & 29 & 29.75 & 265.00 \\
\hline Tom Maior & 29.5 & 25.20 & 30 & 29 & 29 & 30 & 29.5 & 29.25 & 27.25 & 259.50 \\
\hline Imperador o Ipiranga** & 28.5 & 26 & 29.75 & 28.75 & 28.25 & 29.25 & 29.5 & 28.25 & 30 & 258.25 \\
\hline Leandro de Itaquera** & 29.25 & 26.75 & 29.25 & 28.75 & 29.5 & 28.75 & 29.25 & 27.25 & 28.75 & 257.50 \\
\hline
\end{tabular}

Fonte - site Ligasp 
ANEXO B - Modelo do Termo de Consentimento Livre Esclarecido

\section{TERMO DE CONSENTIMENTO LIVRE ESCLARECIDO}

Você está sendo convidado(a) a participar da pesquisa "Escola de Samba em São Paulo: Identidade e Engajamento".

Este trabalho tem como objetivo investigar o processo de transformação da identidade e o engajamento dos componentes na escolas de samba paulistanas de que fazem parte e resultará na dissertação da mestrando Fernanda Fernandes dos Santos, no Programa de Pós Graduação em Mudança Social e Participação Política, da Escola de Artes, Ciências e Humanidade, da USP.

Sua participação nesta pesquisa não é obrigatória e consistirá em conceder uma (ou mais, caso seja necessário) entrevista sobre o seu engajamento e pertencimento às agremiações carnavalescas da capital paulista.

Caso queira manter o anonimato, você poderá indicar um nome fictício. Todas as informações resultantes da(s) entrevista(s) serão utilizadas somente com finalidade acadêmica.

\section{DADOS DO ORIENTADOR}

Prof. Dr. Dennis de Oliveira

Av. Arlindo Bettio, 1000 - Ermelino Matarazzo, São Paulo (SP). Telefone (11) 30918877

Declaro que concordo em participar da pesquisa.

( ) Concordo em divulgar meus dados (nome, sexo, cargo, etc).

( ) Não concordo em divulgar meus dados (nome, sexo, cargo, etc) e sugiro o seguinte nome fictício

São Paulo, de de 2012

(Nome: ) 
ANEXO C - Roteiro semiestruturado de entrevistas

Perguntas prováveis para nortear as entrevistas semiestruturadas que usarei para a análise

1. Nome, idade, profissão, estado civil

2. Como teve contato com o carnaval?

3. Como teve contato com a escola que está no momento (caso não responda na primeira pergunta)?

4. Qual sua função na escola? E quais as atividades que a pessoa que tem esta função tem que fazer desde a escolha do enredo?

5. Há quantos anos faz o que faz na escola?

6. Como se faz para ser bom nesta função?

7. Esta função faz você criar vínculo com a escola? Que tipo de vínculo?

8. A sua família te acompanha? Eles fazem o que? Com o envolvimento familiar é mais fácil desempenhar as atividades?

9. Você já deixou de fazer algo importante por causa da escola de samba? Por causa da função que exerce? Sua função te dá prazer?

10. Você recebe algum tipo de pagamento pelo desempenho da sua função para a escola de samba, na quadra, nos ensaios técnicos ou no sambódromo?

11. Se não recebe, por que exerce a função? Se recebesse, você acha que o envolvimento com a atividade e com a escola seriam diferentes?

12. O trabalho que exerce é gratuito, aquele que você não tem pagamento?

13. Você tem algum contrato ou compromisso firmado com o setor a que está ligado?

14. Já que você não recebe, a função que exerce pode ser classificada como o quê, na sua opinião?

15. O que é trabalho voluntário para você?

16. Você tem algum problema sobre ser chamado de voluntário?

17. Sua função te dá prazer?

18. Você acha que passa por alguma exploração, dentro da função que exerce na escola? 